\title{
Cordaites borassifolius (Sternberg) Unger (Cordaitales) from the Radnice Basin (Bolsovian, Czech Republic)
}

\author{
ZBYNĚK ŠIMŮNEK, STANISLAV OPLUŠTIL \& JANA DRÁBKOVÁ
}

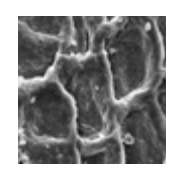

\begin{abstract}
The remains of cordaitalean plants are an important element in Bolsovian plant fossil assemblages from the Radnice Ba$\sin$ (Czech Republic). The study of historic collections and new excavations brings together new data on the Cordaites type species - Cordaites borassifolius. Cordaites borassifolius was probably quite a large tree of monopodial or even sympodial stature. Its trunk diameter was at a minimum $0.5 \mathrm{~m}$. Branches were between $1.1 \mathrm{~m}$ and spaced less than $0.7 \mathrm{~m}$ appart. The bases of the branches usually attained about $2 / 3$ to $1 / 2$ of the trunk width. The abaxial cuticle has stomata arranged in multiplex stomatal rows that formed a wide stomatiferous band. A transverse crypt above the stoma is an important diagnostic feature. The cordaitalean leaves, twigs, pith casts, fertile organs and seeds found are referable to a single natural species. The associated fertile organs belong to two types: 1) male fertile organs Florinanthus volkmannii and 2) a more robust, probably female, form similar to Cordaitanthus ovatus. Cuticles from the scales and long bracts of Florinanthus volkmannii have been studied in detail. Most scale cuticles are astomatal, but stomata may occur very rarely on some parts of the abaxial cuticle. Small trichomes grew from the scale margins. The cuticle of the bract has elongate cells and stomata are arranged in single stomatal rows on the abaxial cuticle. Many bilateral monosaccate pollen grains [Florinites ovalis, Florinites guttatus and Pseudoillinites, with a central body bipolar attachment to the equatorial saccus were separated from scale surfaces of Florinanthus volkmannii. The pith cast belong to the species Artisia approximata. The seeds are small and of the "Cardiocarpus-type". Cordaites borassifolius grew in wet, peat-forming habitats and they were most likely trees of medium height. $\bullet$ Key words: Carboniferous, Radnice Basin, Cordaites, cuticles, cordaitalean fertile organs.
\end{abstract}

S̆IMƯNEK, Z., OPLUŠTIL, S. \& DRÁBKOVÁ, J. 2009. Cordaites borassifolius (Sternberg) Unger (Cordaitales) from the Radnice Basin (Bolsovian, Czech Republic). Bulletin of Geosciences 84(2), 301-336 (33 figures, 3 tables). Czech Geological Survey, Prague. ISSN 1214-1119. Manuscript received March 6, 2009; accepted in revised form May 22, 2009; published online June 18, 2009; issued June 30, 2009.

Zbyněk Šimůnek \& Jana Drábková, Czech Geological Survey, Klárov 3/131, 11821 Praha 1, Czech Republic, zbynek.simunek@geology.cz, jana.drabkova@geology.cz・Stanislav Opluštil, Faculty of Sciences, Charles University Praha, Albertov 6, 12843 Praha 2, Czech Republic, oplustil@natur.cuni.cz.

Recent excavations of fossil-bearing tuff bed (called bělka) at the base of the Whetstone Horizon at the Ovčín locality in the Radnice Basin (Opluštil et al. 2009) has provided a collection of well preserved plant fossils representing a peatforming vegetation buried in growth position by volcanic ash. Due to this unique burial history, different plant organs derived from the same plant are preserved in a natural association with the parent stem. These remains include cordaitalean leaves, pith casts, fertile organs such as cones and seeds, branches and several metre long stems. Cuticles isolated from 11 leaves found at the Ovčín locality are all conspecific with cuticles prepared from the holotype Cordaites borassifolius (Sternberg) Unger, described by Sternberg (1821) from the Radnice Basin as the remains of a palm - Flabellaria borassifolia. Since all the cordaitalean leaves found at the Ovčín locality appear to represent Cordaites borassifolius it seems that associated stems, branches and fertile or- gans could also belong to this species. Therefore this contribution is focused on evaluating the potential of these new findings for the reconstruction of Cordaites borassifolius.

\section{Geological setting}

Samples of Cordaites borassifolius discussed in this paper were recovered from the Radnice Basin, which represents only a small part of an extensive complex of late Palaeozoic continental basins in the Czech Republic (Fig. 1A). Sedimentary fill of these basins in Central and Western Bohemia ranges from the middle Westphalian (Bolsovian) through to late Stephanian (Pešek 1994) and it is divided into four formations (Fig. 2) based on the alternation of red beds and grey, coal-bearing strata (Weithofer 1902). However, in the Radnice Basin, only the lower part of the oldest 

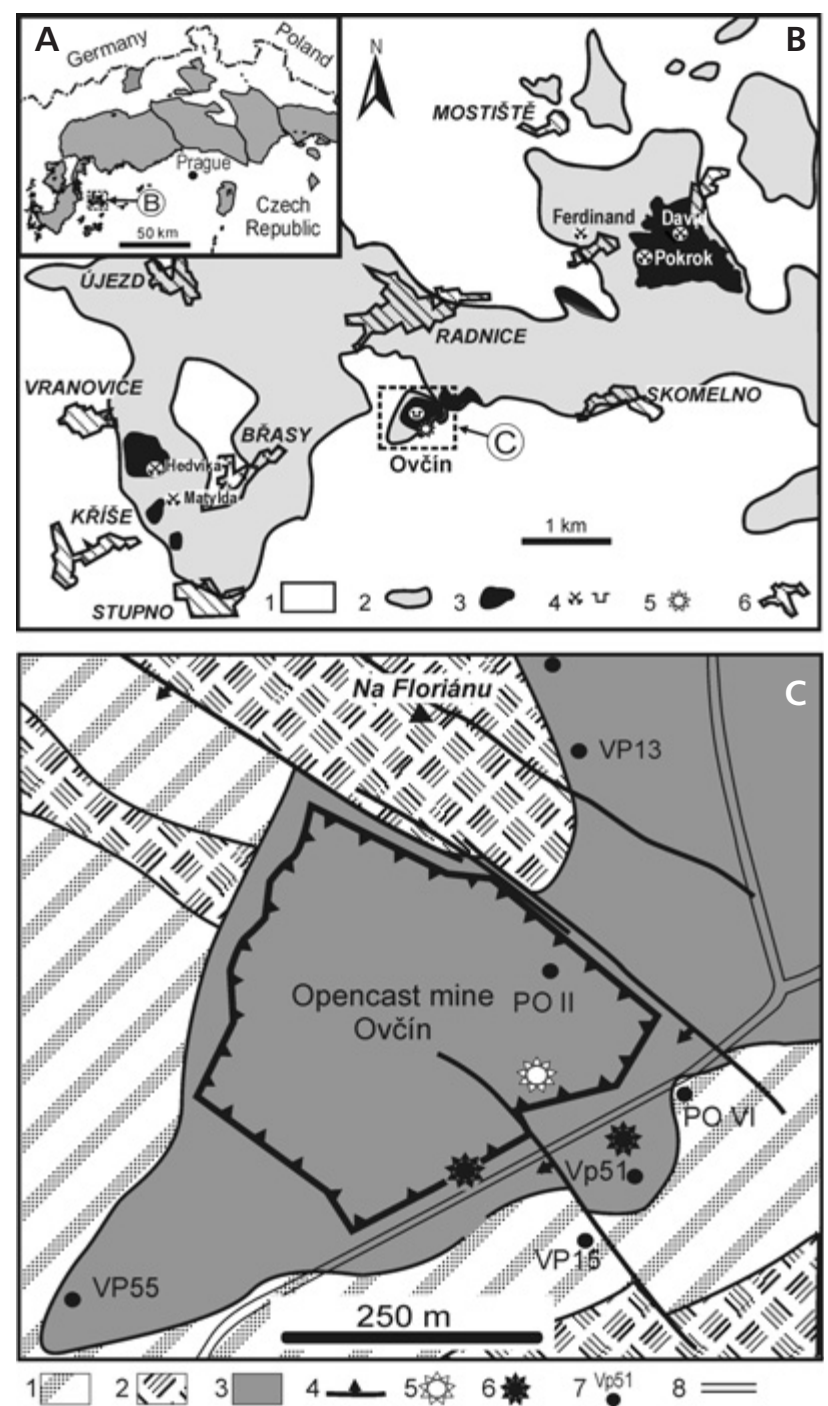

Figure 1. Location of the study area. A - Late Palaeozoic continental basis of the Czech Republic. Circled B shows the position of the Radnice Basin. B - Radnice Basin and adjacent relicts of Carboniferous sediments (1 - Pre-Carboniferous rocks, 2 - Carboniferous sediments, 3 - Lower Radnice Coal in workable thickness and quality, 4 - closed mines/opencast mines, 5 - excavation at the Ovčín locality, 6 - urbanised area). Circled $\mathrm{C}$ shows the position of the Ovčín locality. $\mathrm{C}$ - geological map of the Ovčín locality with the position of the Ovčín opencast mine and excavations. 1, 2 - Proterozoic basement (1 - shales, 2 - basic volcanites), 3 - Radnice Member, 4 - fault, 5 - site of cordaitalean remains collected in the opencast mine, 6 - excavations (OE - Ovčín Excavations, SE - Sternberg Excavations), 7 - borehole, 8 - road.

unit, the Kladno Formation, is preserved. These sediments belong to the Radnice Member (Bolsovian), which is the most important coal-bearing unit of the basins in Central and Western Bohemia. In the Radnice Basin, coal seams are represented by the Lower and Upper Radnice Coals, which together comprise the Radnice group of seams. The Lower Radnice Coal is usually 1-4 m thick. The Upper Radnice Coal is the most important seam of the basin, lo-

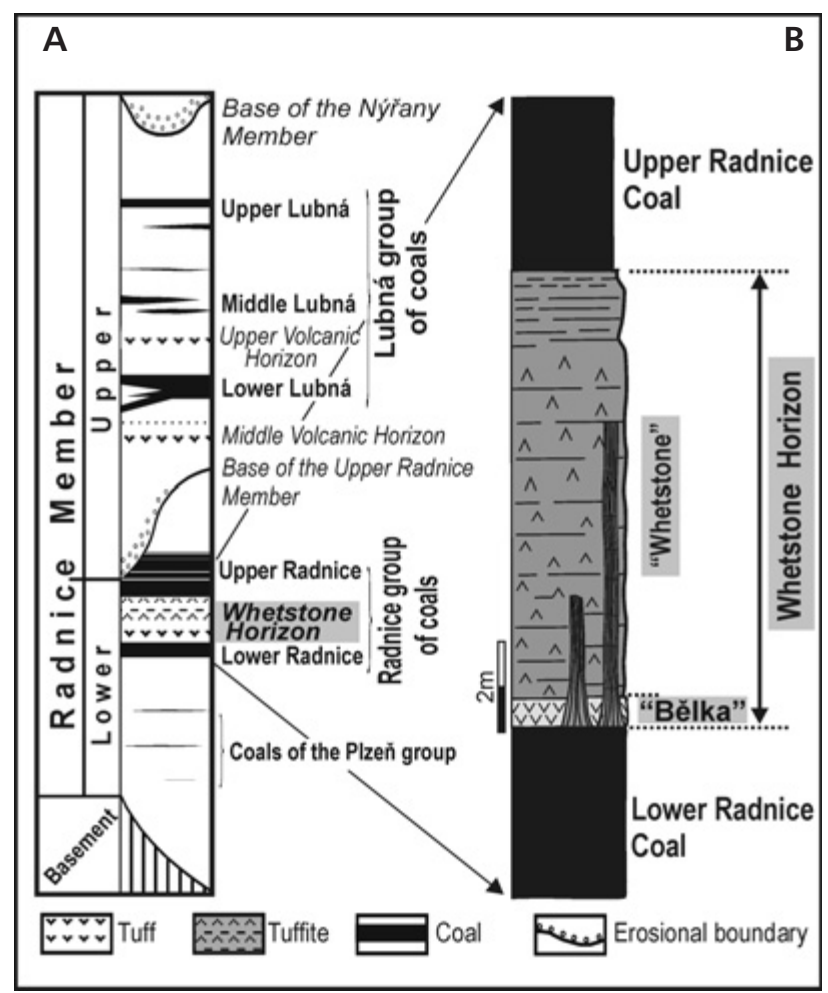

Figure 2. Lithostratigraphy of the Radnice Member (A) and architecture of the Whetstone Horizon at the Ovčín locality (B).

cally $>10 \mathrm{~m}$ thick. Both coal seams are separated by the Whetstone Horizon, which tends to be a few meters thick but locally can reach over $10 \mathrm{~m}$ in thickness. The Whetstone Horizon has a sharp contact with the underlying rock above which is a $0.6 \mathrm{~m}$ thick basal unit of pale yellow fossiliferous tuff (the "bělka"), overlain by up to $10 \mathrm{~m}$ of the "whetstone", poorly- to well-laminated tuffitic claystone and mudstone (Fig. 2). The bělka or tuff bed contains upright standing stems of peat-forming plants. Observation of the distribution of plant remains and their mode of occurrence indicates a simple burial history of the former peat-forming forest (Opluštil et al. 2007, 2009). In contrast, the overlying tuffitic mudstones (whetstone) contain only detrital plant remains concentrated on discrete bedding surfaces. The occasional larger plant fragments are randomly scattered within the unit. In the upper part of the whetstone, vertebrate and insect ichnofossils are frequently found (Turek 1989). Plant fossils of the Radnice Basin are mostly preserved in the Whetstone Horizon between the Lower and Upper Radnice Coals, and from the siliciclastic or volcanoclastic partings and roof shale of the Upper Radnice Coal.

\section{Material}

Apart from Sternberg's holotype of Cordaites borassifolius (Sternberg) Unger and Corda's specimens from Svinná 

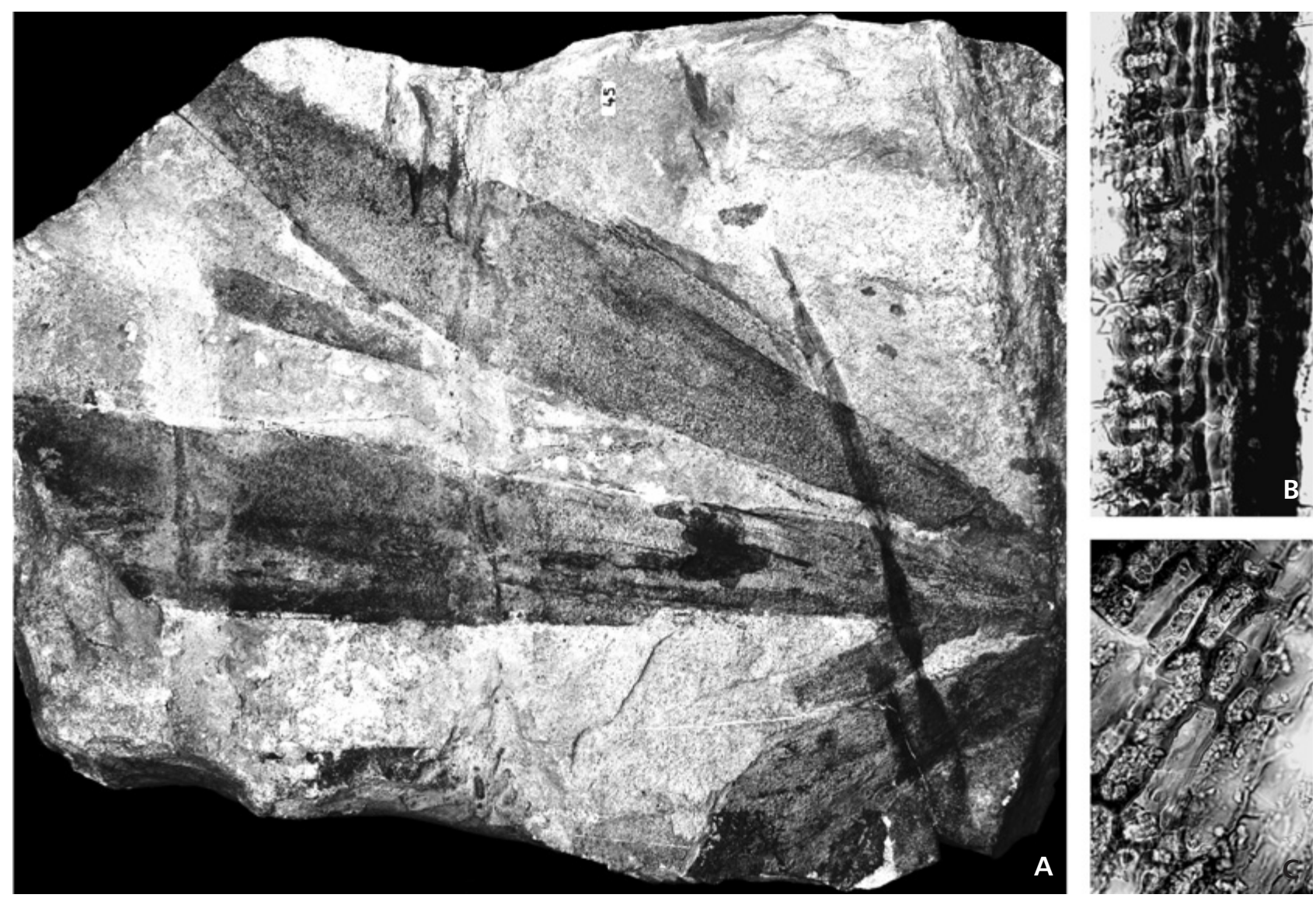

Figure 3. Cordaites borassifolius (Sternberg) Unger. • A - holotype, locality Svinná, Radnice Basin, Coll. Sternberg, National Museum Prague, No. E $5738, \times 0.3$. B - abaxial cuticle with stomatal row isolated from the specimen on Fig 3 A. Stomata have typical stomatal crypt. Slide No. $347 / 2, \times 300$. - C - adaxial cuticle isolated from the specimen on Fig 3A. Slide No. 347/2, × 300 .

in northern part of the Radnice Basin (Figs 3A, 7), the study material described herein was collected at the Ovčín locality near the town of Radnice in the southern part of the Radnice Basin (Fig. 1). At this locality plant remains were collected mostly in the 1980's during the operation of the opencast Ovčín Mine (formerly Pokrok Opencast Mine). Several tens of thousands of plant remains mostly from the berlka bed, forming the roof of the Lower Radnice Coal, with fewer specimens being from the associated siliciclastic sediments, were collected during the 8 years of the opencast operation (the mine was closed in 1986). All the fossils are now housed in the collections of the National Museum in Prague. This material includes cordaitalean leaves with excellently preserved cuticles from the bělka. Since the mine closed, additional specimens were collected during excavation of the fossiliferous bělka bed lateral to the extent of the opencast mine. In all, five excavations of the basal Whetstone Horizon between 2002 and 2006, have exposed a total area of about $150 \mathrm{~m}^{2}$. Three excavations named Ovčín excavation 1, 2, and 3 (OE1, 2, and 3) are located just at the edge of the former Ovčín opencast mine (Fig. 1). They exposed a continuous area of about $100 \mathrm{~m}^{2}$.
The other two excavations, Sternberg 1 (2005) and 2 (2006) (SE1, and 2) are located about $100 \mathrm{~m}$ east of the opencast mine margin and $200 \mathrm{~m}$ northeast of OE 1, 2, and 3 (Fig. 1). SE 1 and 2 exposed an area of about $50 \mathrm{~m}^{2}$. The main purpose of these excavations was the study of species composition and structure of peat-forming forest. Therefore, the exposed surface was cleaned and grided by string into $1 \mathrm{~m}^{2}$ units for precise location of the fossils. The tuff was then carefully removed in slabs and all the fossils were documented on a piece of graph paper unique to each grid unit. Such data provided detailed information about spatial distribution of species (Fig. 8D). The cordaitalean remains from the opencast mine and excavations include fragments of stems, branches, pith casts and leaves, some attached to branches, as well as reproductive organs including male and female cones and isolated seeds. The largest cordaitalean fragment was about $6 \mathrm{~m}$ long, a monopodially branched stem found in SE1 (Fig. 6). Although this stem was leafless, it was associated with shed leaves of Cordaites borassifolius. All these findings contributed significantly to the whole-plant reconstruction of the species. These large specimens are stored in the West Bohemian 
Museum in Plzeň, where they are in the process of restoration and preparation. More than 30 fragments of Cordaites borassifolius leaves have been used in this study, and cuticular slides are stored in the Czech Geological Survey in Prague.

Cordaites borassifolius (Sternberg) Unger. - Material: About 100 specimens from the Přivětice - Ovčín locality, Pokrok Mine and new excavations OE1, 2, and 3, Radnice Basin, Radnice group of coals, Whetstone Horizon. The samples are stored in the National Museum, Prague (Nos. E 4749, E 4750, E 5738, E 5889-E 5892, E 5895-E 5898, E 6221-E 6223), Czech Geological Survey, Prague (No. ZŠ 301) and West Bohemian Museum, Plzeň (Nos. F 07705, F 07927, F 07931, F 07943, F 07952, F 07958, F 08044, F 08083, F 08084, F 08086, F 08132, F 08192, F 08197, F 08255, F 08333, F 08339, F 08414, F 08443, F 10578, FX 1, FX 3-5, FX 7-13). Cuticular slides: (Ovčín): 108/1-6; 120/1-3; 352/1-5; 353/1-2; 354/1-5; 355/1-5; 356/1-6; 357/1-3; 358/1-5; 416/1-23; 417/1-5; 468/1-8; (Svinná - holotype): 347/1-2 stored in the Czech Geological Survey in Prague.

Cordaitanthus ovatus (Lesquereux) Ignatiev \& Meyen. Material: West Bohemian Museum, Plzeň (Nos. F 02193, F 08058, FX 14-17).

Cardiocarpus annularis (Sternberg) Lesquereux. - Material: Sternberg's (1820) specimens are stored in the National Museum, Prague under the numbers E 1207 and E 1208. About 20 seeds from SE2 are stored in the West Bohemian Museum in Plzeň (Nos. F 07986A, B, F 08449A, B, C, FX 10-13); cuticular slides: 469/1-5 are stored in the Czech Geological Survey in Prague.

Florinanthus volkmannii (Ettingshausen) comb. nov. Material: Several cones on one slab from the National Museum, Prague No. E 5896 (Pokrok opencast mine) and from the Ovčín excavation 2006 (SE) - West Bohemian Museum, Plzeň Nos. FX 6 and FX 9; cuticular slides: 416/1-23 stored in the Czech Geological Survey in Prague.

Artisia approximata Lindley \& Hutton. - Material: West Bohemian Museum, Plzeň. Nos. F 08167, F 08168, F 08043, F 08045, F 08046, F 08059, F 08065, F 08074, F 08128, F 08129, F 08131, F 08139, F 08140, F 08142, F 08232, F 08331, F 08335, F 08389, F 08411, F 08426, F 08427, F 08442, F 08445, FX 2.

\section{Methods}

Cuticles were prepared according to the method described by Kerp (1990). Coalified leafy fragments were separated from the rock by placing it in concentrated hydrofluoric acid (HF) for several hours. The isolated fragments were then bleached in Schulze's reagent $\left(40 \% \mathrm{HNO}_{3}\right.$ with crystals of $\mathrm{KClO}_{3}$ according to Krings \& Kerp 1997 and Kerp \& Krings 1999), a procedure which lasted 20 to 73 hours depending on preservation. After treatment in Schulze's reagent, cuticles were washed in $10 \%$ potassium hydroxide $(\mathrm{KOH})$ and finally rinsed in distilled water. Some cuticles were stained with safranin for several hours to accentuate anticlinal walls and stomata. Before embedding in glycerine gelatine, the cuticles were dehydrated in pure glycerine. The remaining cuticular fragments were affixed to film for observation under SEM.

\section{Systematic section}

Division Gymnospermophyta ('seed plants')

Class Pinopsida

Order Cordaitanthales ('cordaites') Meyen, 1984

\section{Genus Cordaites Unger, 1850}

Type species. - Cordaites borassifolius (Sternberg) Unger

\section{Cordaites borassifolius (Sternberg) Unger}

Figures 3, 7, 8

1821 Flabellaria borassifolia Sternberg; Sternberg, vol. I, 2: tent. 28, 32, pl. 18.

1825 Flabellaria borassifolia Sternberg; Sternberg, vol. I, 4: tent. 34, pl. 34, fig. 1.

1825 Cycadites palmatus Sternberg; Sternberg, vol. I, 4, p. 39, tent. 33, pl. 40.

1845 Flabellaria borassifolia Sternberg. - Corda, p. 44, pl. 24, figs $1-3,8$.

1850 Cordaites borassifolia Sternberg sp. - Unger, p. 227.

1852 Cordaites borassifolia Ung. - Ettingshausen, pp. 16, 17 , pl. 5 , fig. 5 .

1968 Cordaites borassifolius Sternb. - Němejc, p. 219, pl. 26, fig. 1.

2000 Cordaites borassifolius (Sternberg) Unger. - Šimůnek, p. 29, figs 3-12.

2001 Cordaites borassifolius (Sternberg) Unger (morphotype 12 sensu Šimůnek 2000). - Šimůnek, fig. 35, pl. 1, figs 1, 2; pls 24-28.

2003 Cordaites borassifolius (Sternberg) Unger. - Zodrow, Mastalerz \& Šimůnek, p. 97, figs 1A, B, D and 2.

2007 Cordaites borassifolius (Sternberg) Unger. - Šimůnek, pp. 131-133, fig. 29a-j, pl. 1, figs 1, 2, pls 24-28, figs .

Holotype. - Figured by Sternberg (1821), pl. 18, National Museum, Prague, No. Akc. 36675, E 5738. 


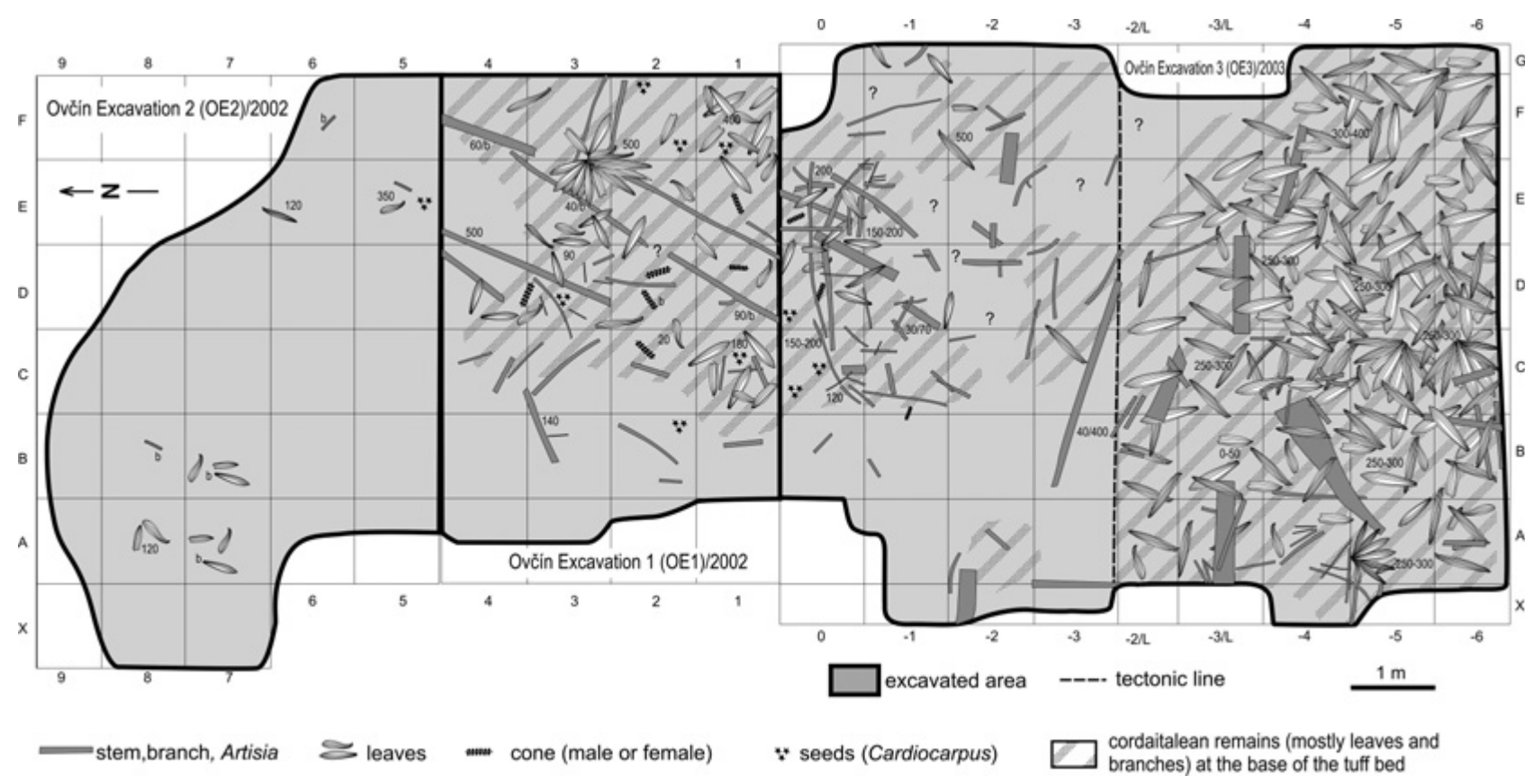

Figure 4. Distribution of remains of Cordaites borassifolius in the excavations Ovčín 1-3. Numerical values given in the format (e.g., 30/150) correspond to diameter of branches or stems $(e . g ., 30 \mathrm{~mm})$ and height above the top of the Lower Radnice Coal at which the remains were found (e.g., $150 \mathrm{~mm}$ ). In this context, "b" means found at base of bělka tuff bed. If only a single value given, it relates to the distance above the roof of the Lower Radnice Coal.

$\leftarrow \mathbf{z -}$

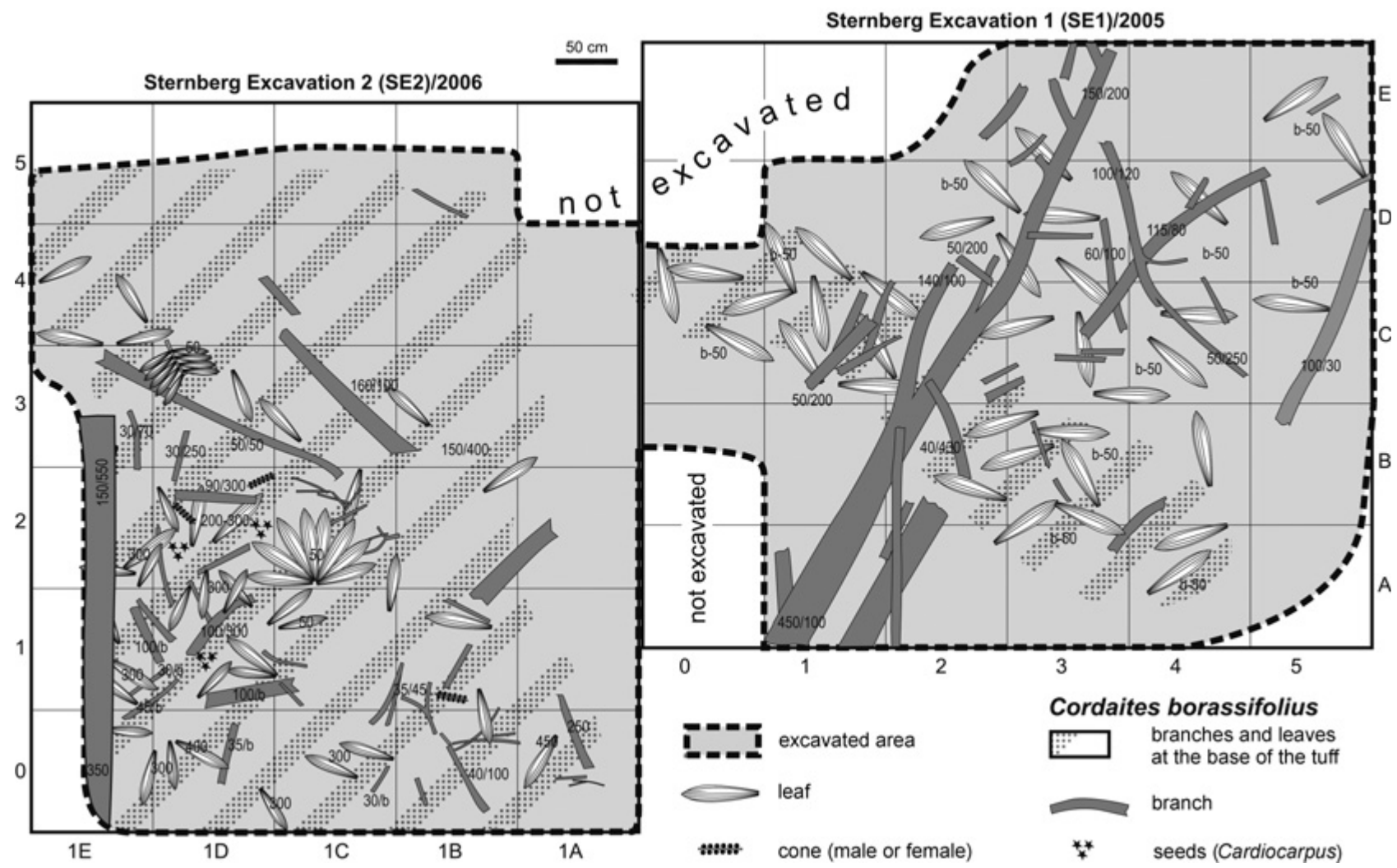

Figure 5. Distribution of remains of Cordaites borassifolius in the excavations Sternberg 1 and 2. 


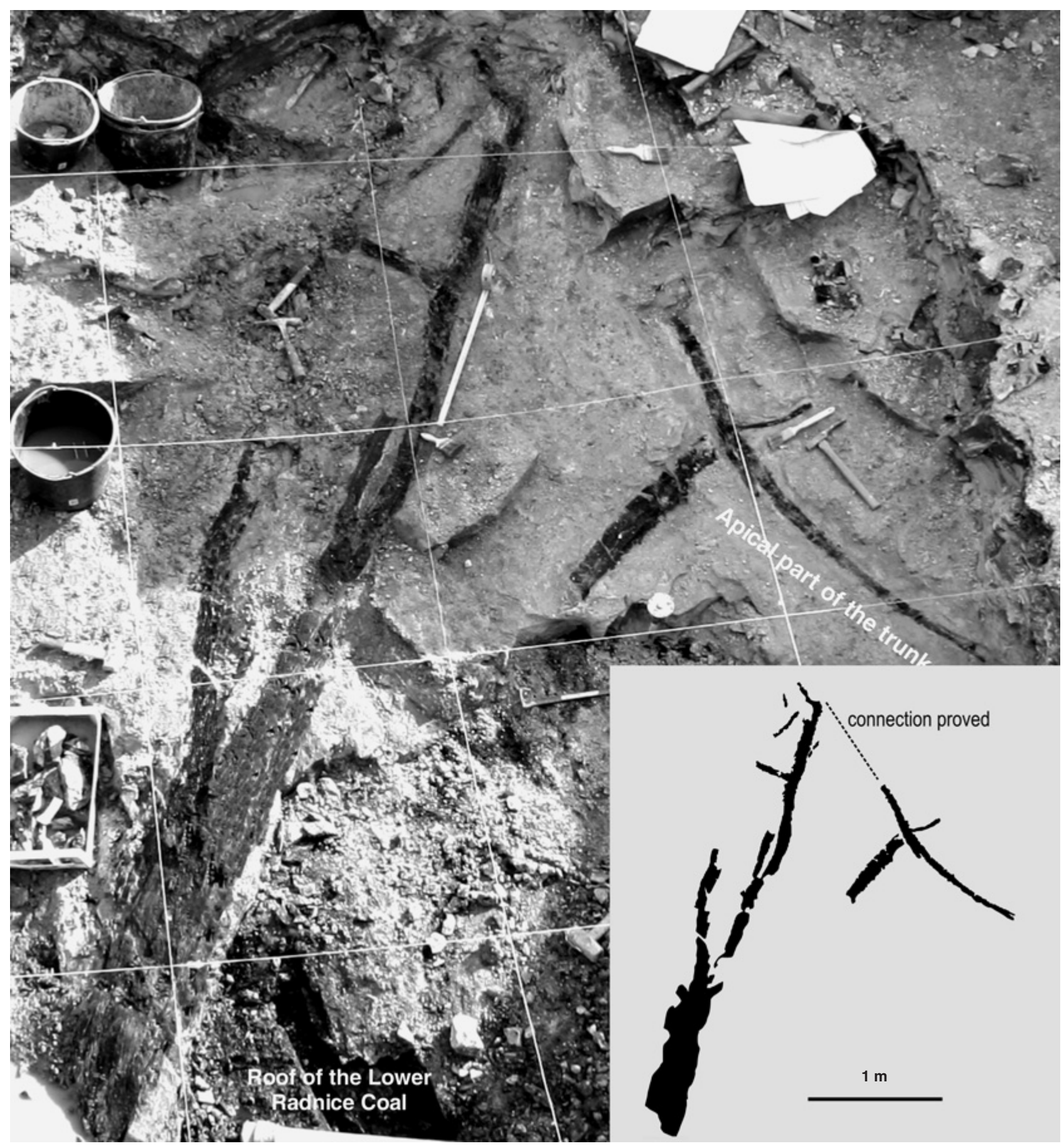

Figure 6. A trunk of Cordaites borassifolius (Sternberg) Unger in the excavation trench at the Ovčín locality (2005).

Type locality. - Svinná near Radnice, Radnice Basin.

Type horizon. - Kladno Formation, Radnice Member, Radnice group of seams, Whetstone Horizon, Carboniferous, Bolsovian.

Emended diagnosis. - Amphistomatic leaves large, entire, thick, ovate-lanceolate, apex bluntly pointed, occasionally deeply lacerated, veins medium-dense to dense. On adaxial side all veins approximately of the same thickness, on abaxial side 1 or 2 thin veins alternate with each thick vein. Abaxial cuticle with tetragonal, oblong square cells and irregularly dispersed stomata, abaxial cuticle with oblong cells and stomata arranged in stomatal rows forming stomatiferous bands. Polar cells rounded, lateral cells oblong to reniform. Tranverse oval crypt constricted in the center. 
Description of the holotype. - The holotype is preserved as an imprint without coal matter on a $440 \mathrm{~mm}$ long and $350 \mathrm{~mm}$ wide (Fig. 3A) slab which is also without coal matter. It consists of two large leaf fragments and several small fragments. The largest fragment is in the middle of the leaf rosette. It is $425 \mathrm{~mm}$ long and $50 \mathrm{~mm}$ wide at its widest part in the middle. Another leaf is preserved behind this first one, as can be seen in Sternberg's (1821) figure. The leaf on the left is $390 \mathrm{~mm}$ long and $58 \mathrm{~mm}$ wide in its middle part. The leaf margins taper towards the base and towards the apex, which is not preserved in this slab. Another three narrow leaf fragments occur among the large, wide leaves. These smaller fragments were apparently enrolled before burial. There are another three smaller leaf fragments to the right from the middle of the large fragment, the largest of which is about $180 \mathrm{~mm}$ long and $40 \mathrm{~mm}$ wide. However, this cannot have been its full length, as the base and apex are not preserved. The base is also not preserved in these three leaves, and the smallest width represented is $18 \mathrm{~mm}$. Due to the coarse nature of the rock, the venation is preserved in only a few parts. It is very dense and partly discontinuous. About 50 wide veins occur in $1 \mathrm{~cm}$ of leaf.

External morphology. - Trunk and branches: The ideas regarding whole-plant morphology are based on new material from SE1, a section of trunk about $5 \mathrm{~m}$ long with several articulated branches (Fig. 5) as well as several branches terminated with palm-like arranged leaves. The preserved length, however, exceeds the size of the excavation so that only the middle part of the trunk could be documented. The lower part of the exposed trunk, about $50 \mathrm{~mm}$ above the coal, is between 450 and $500 \mathrm{~mm}$ wide. The width of the opposite end of the stem is about $100 \mathrm{~mm}$. The upper part of the trunk was, however, broken off and buried next to the main trunk (Figs 5, 6). It is approximately $2.7 \mathrm{~m}$ long and its apex is absent. The entire height of the tree was estimated based on Niklas (1994) formula $\left[\log _{10} \mathrm{H}=1.59+\right.$ $0.39\left(\log _{10} \mathrm{D}\right)-0.18\left(\log _{10} \mathrm{D}\right)^{2}$, where $\mathrm{H}=$ tree height and $\mathrm{D}=$ base diameter of stem], which suggested a height between 28.1 and $28.6 \mathrm{~m}$ for the tree with a trunk diameter of $500 \mathrm{~mm}$. However, such height seems unlikely because the main axis exposed in the excavation exhibits a rapid decrease in diameter distally (from 450 to $150 \mathrm{~mm}$ over a length of just $5.7 \mathrm{~m}$ ) due to sympodial branching. Therefore, we believe that the tree was of the order of 15 to $20 \mathrm{~m}$ in height (Opluštil et al. 2009). The specimen displays monopodial to sympodial branching with four or five main lateral branches, of which only the basal parts are preserved. Some of them display the typical Artisia-type of pith cast (Fig. 20H). Monopodial branching is demonstrated in Fig. 20G. The branching apparently began only a few metres from the base of the tree, resulting in a plant that probably had a laterally and vertically wide crown. The dis-

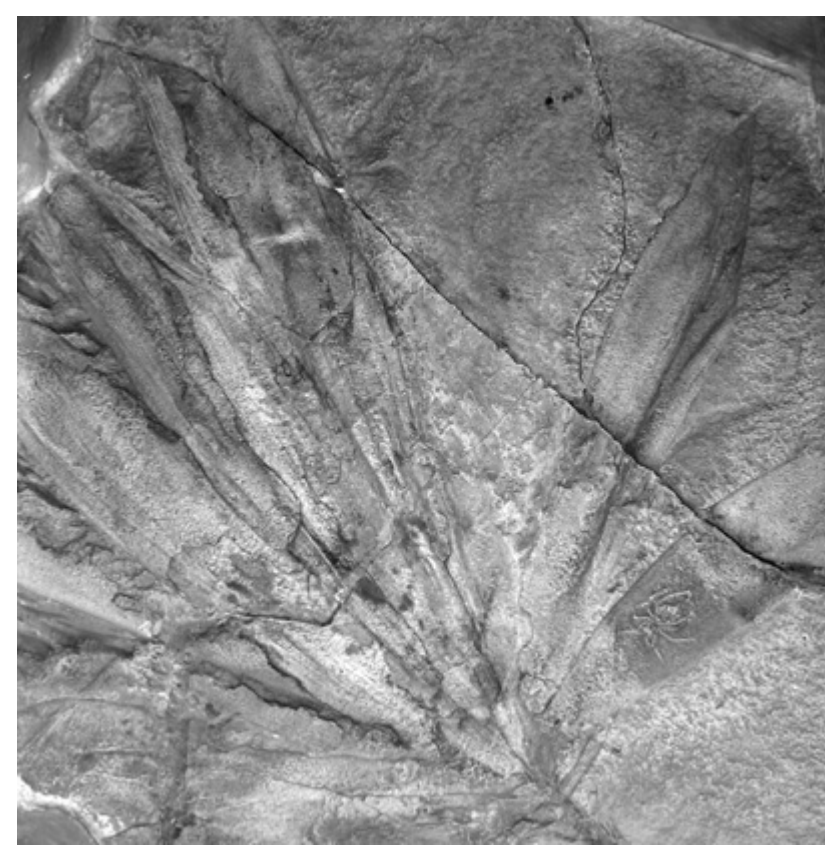

Figure 7. Cordaites borassifolius (Sternberg) Unger. Leafy apex of a twig. Counterpart of Corda's (1845) specimen figured on pl. XXIV, fig. 1; loc. Svinná, Radnice Basin, Bolsovian, Coll. National Museum, Prague, No. E $4270 . \times 0.2$.

tance between neighbouring branches decreases upward, from about $1.1 \mathrm{~m}$ in the lower part of the trunk to about $0.7 \mathrm{~m}$ in its upper part. The existence of other branches on the opposite side of the trunk cannot be proved. The bases of the branches usually attain about $2 / 3$ to $1 / 2$ of the trunk width. The angle of branching of the two lowest branches is acute $\left(10^{\circ}\right.$ and $\left.30^{\circ}\right)$, whereas that of the upper two branches is more obtuse $\left(60^{\circ}\right.$ and $\left.85^{\circ}\right)$. However, it is possible that the preserved branching angles have been modified by volcanic ash load and post-sedimentary compaction, especially in the lower part of the trunk.

Leaves: No leaves have been found attached to the trunk, but a few $C$. borassifolius leaves were found in close associatiation with the trunk or its branches. This observation, in combination with the fact that all of the branches were leafless, points to the conclusion that this tree had already fallen prior to the eruption. These leaves were probably derived from neighbouring cordaites trees standing only few metres away.

In other excavations (OE2, 3 and SE2), branches with spirally arranged organically attached leaves were found. Leaves are, entire, ovate-lanceolate, rarely obovate, maximum width 35-90 mm, length 400-700 $\mathrm{mm}$. In the SE 2 and $\mathrm{OE} 1$ and 3 excavations (Fig. 4, 8D), the leaf length was mostly between 450 and $550 \mathrm{~mm}$ being $493 \mathrm{~mm}$ on average. The terminal leaf rosette of Corda's specimen from the Svinná locality (Fig. 7, National Museum, No. E 4270) is preserved without leaf terminals, unfortunately. Leaf 

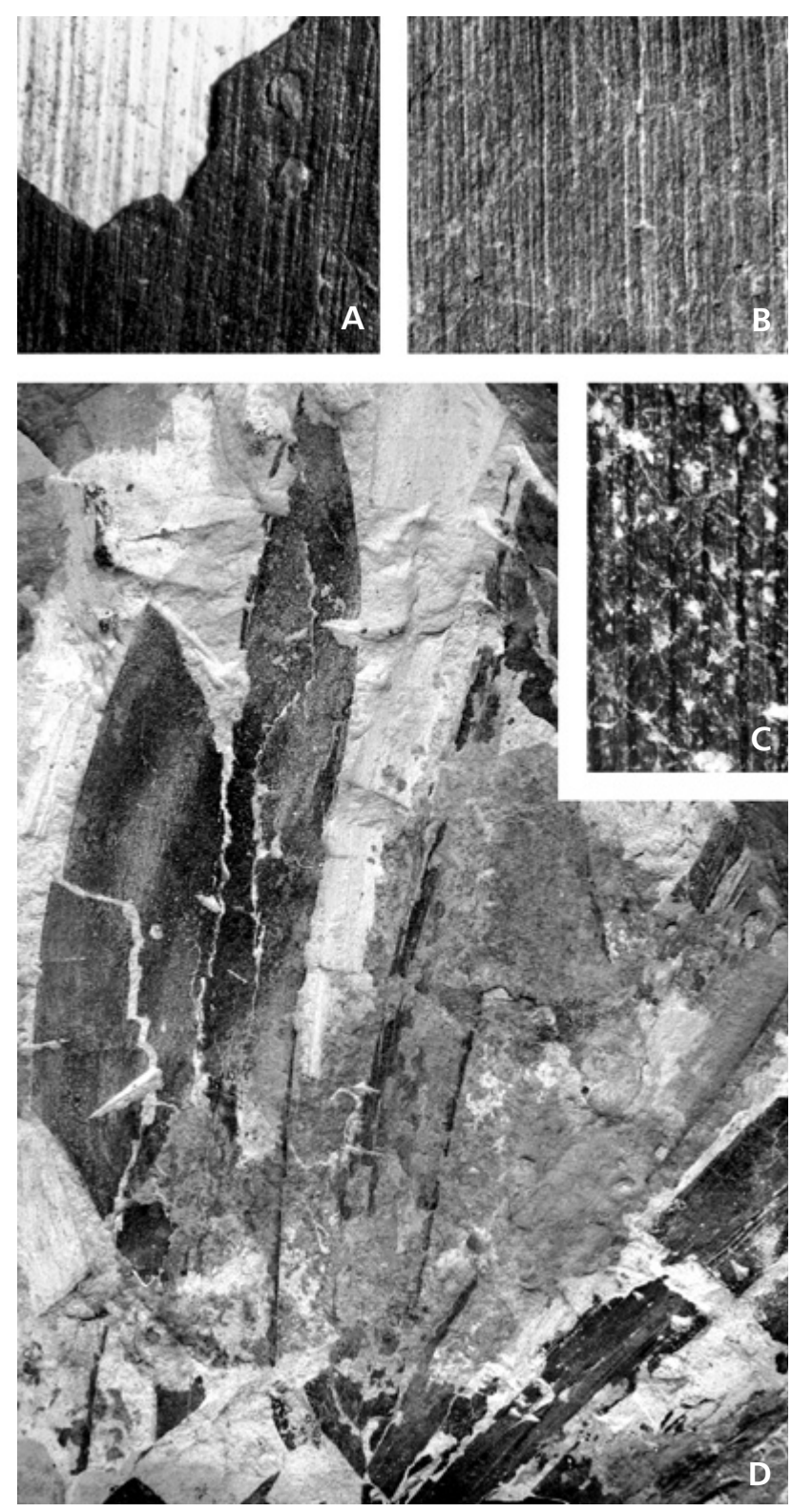

Figure 8. Cordaites borassifolius (Sternberg) Unger, locality Ovčín near Radnice, Pokrok Mine, Radnice Member, Bolsovian. • A - venation from a leaf, coll. National Museum, Prague, No.: E 5898; adaxial surface is white, abaxial surface is black. $\times 8$. $\bullet \mathrm{B}-$ venation with dense veins, probably of abaxial surface, coll. West Bohemian Museum, Plzeň, $\times 8$. - $\mathrm{C}$ - venation with sparse veins alternating with very thin veins, probably of adaxial surface, coll. West Bohemian Museum, Plzeň, $\times 8 \cdot \bullet D-$ several leaves from the terminal part of a twig,. West Bohemian Museum, Plzeň, $\times 0.4$.

fragments are up to $500 \mathrm{~mm}$ in length. The leaf bases are 13-15 mm wide. Apices are bluntly pointed, but often apparently acute (because of the inrolling of the leaf margins). The leaves are seldom lacerated. Selected leaf specimens were used for statistical evaluation. The leaf length could only be measured on 13 specimens (Fig. 9), and therefore the histogram is biased. Most of the leaves from

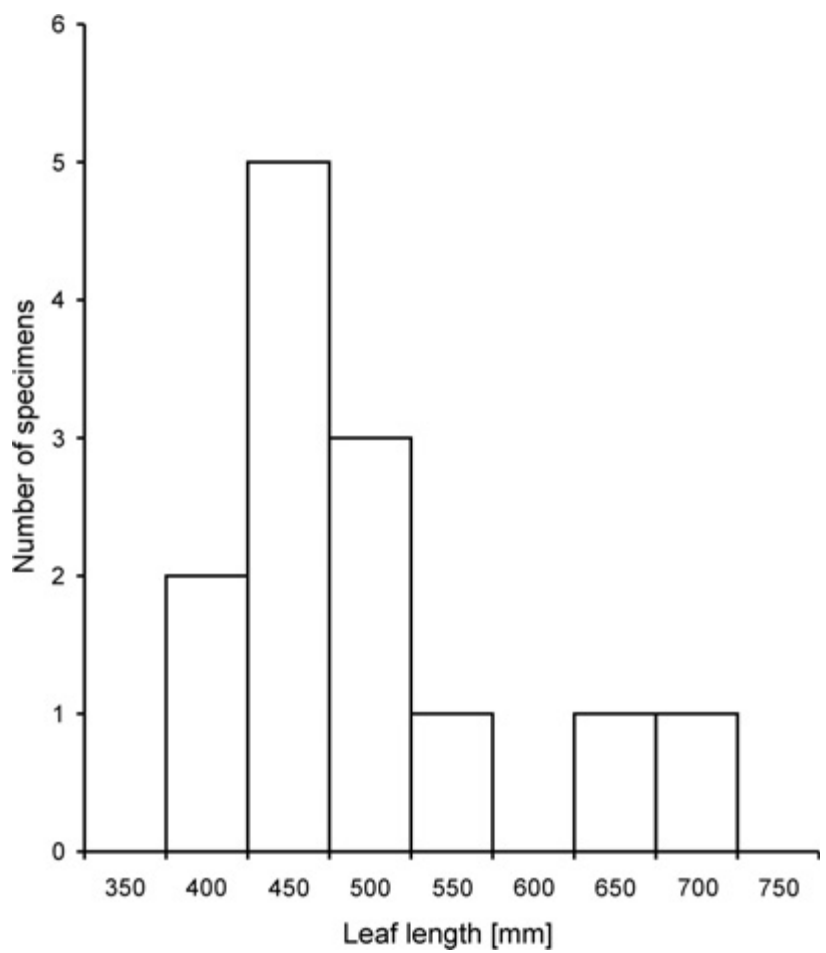

Figure 9. Histogram of relative frequencies of leaf length of Cordaites borassifolius (Sternberg) Unger plotted for 13 specimens.

Ovčín are 450 to $550 \mathrm{~mm}$ long. The longest specimen, $700 \mathrm{~mm}$, is from Sternberg's holotype. The mean length is $493 \mathrm{~mm}$. The leaves are often fragmentary thus width measurements do not usually represent the maximum, The measurement of 48 specimens produced highly variable results as the measurements were taken at different positions on the leaves relative to where the widest point would have been. The narrowest fragmentary leaves are only 15-20 mm wide (Fig. 10). They represent basal or apical parts of leaves. Most of the leaves are about $35 \mathrm{~mm}$ wide and many samples are in the interval from 45 to $60 \mathrm{~mm}$. Several samples are up to $92 \mathrm{~mm}$ wide. The mean of this varied width is $45 \mathrm{~mm}$. Fig. 11 shows the correlation between leaf length and width based on 13 complete leaves. If we use data from only these 13 specimens for calculation of the mean width, we find that $60 \mathrm{~mm}$ is the mean width. The symbols shown in Fig. 11 represent the maximum width of leaves.

Veins: The leaf veins are straight, parallel to the margins and to each other. The venation pattern depends on whether the adaxial or abaxial side is viewed, and on preservation. Usually one (or two) narrow veins alternate with one wide (or "true") vein. The number of veins per $1 \mathrm{~cm}$ ranges considerably, from 18-62. By means of the cuticles, it is possible to distinguish which parts represent the narrow and wide veins. The vein densities typically fall within a range from 24 to 26 veins per $\mathrm{cm}$ and 46 to 50 veins per $\mathrm{cm}$. The 


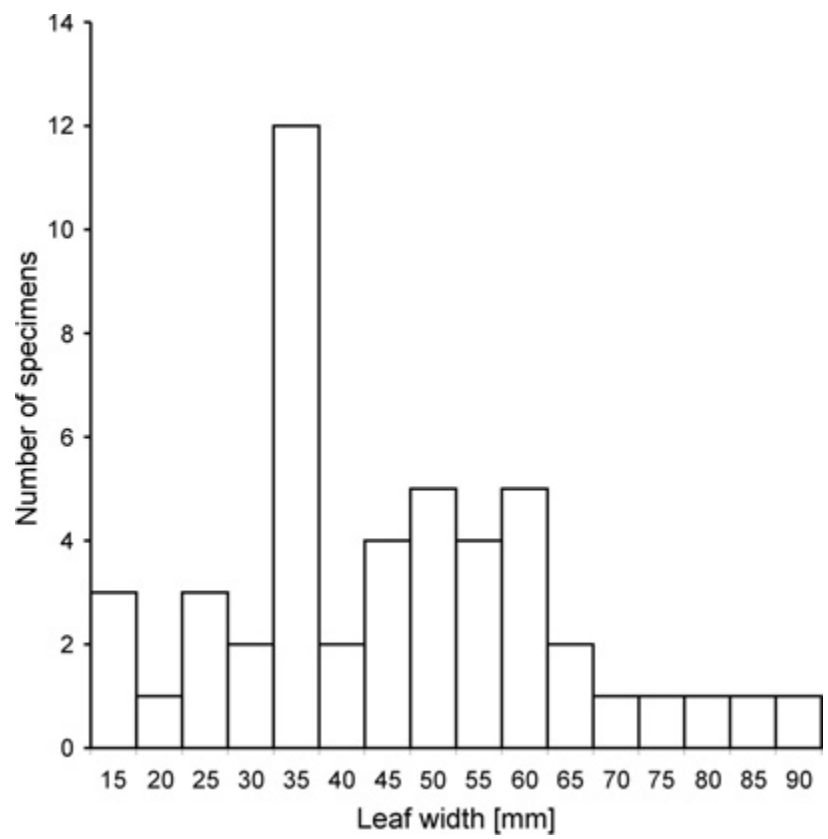

Figure 10. Histogram of relative frequencies of leaf width of Cordaites borassifolius (Sternberg) Unger plotted for 48 specimens.

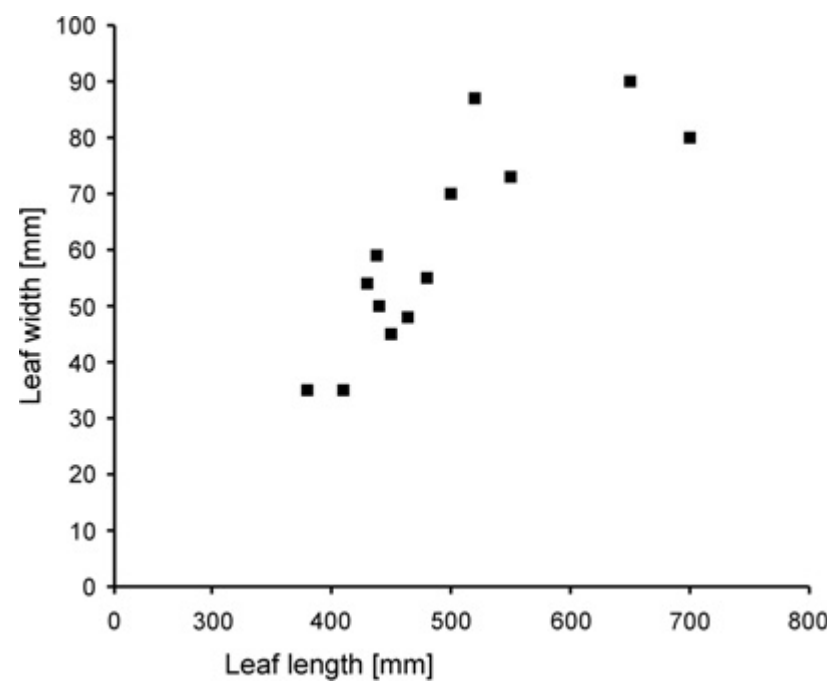

Figure 11. Graph showing the correlation between the length and width of Cordaites borassifolius (Sternberg) Unger leaves plotted for 13 specimens.

former values probably represent the abaxial side, where the costal fields are prominent, whereas the latter values probably represent the adaxial side, where the wide veins are thinner and sometimes difficult to distinguish from the thin veins. The number of veins per $1 \mathrm{~cm}$ is shown on Fig. 12 based on 34 specimens. It was taken from the widest part of the studied leaf fragment. The veins terminate at the margin. Even though the mean is 34.3 veins per $\mathrm{cm}$, the histogram has two peaks. The peak with a value of 26 veins per cm probably represents the adaxial side (Fig. 8A, C), where differences between the vascular bun-

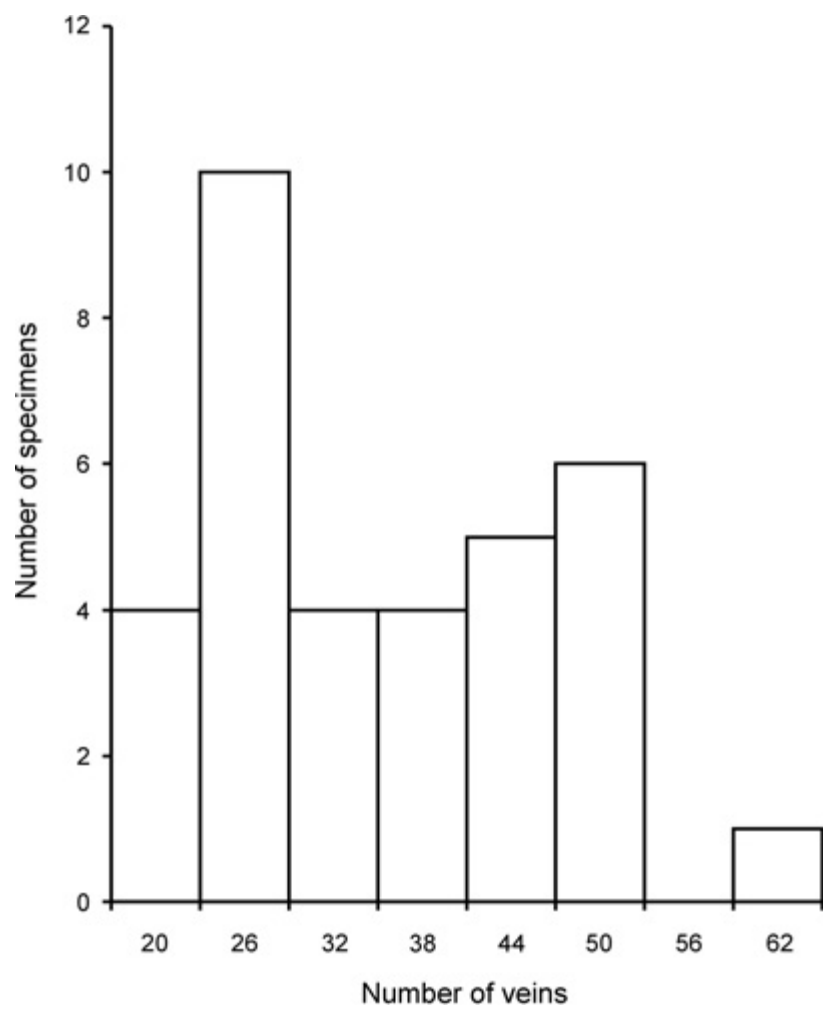

Figure 12. Histogram of relative frequencies of number of veins per $1 \mathrm{~cm}$ for Cordaites borassifolius (Sternberg) Unger leaves plotted for 34 specimens.

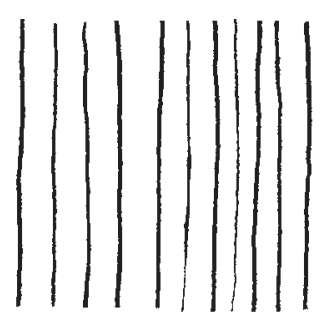

a

Figure 13. Venation of Cordaites borassifolius (Sternberg) Unger. - a - adaxial side, $\bullet$ b - abaxial side with two different vein thicknesses, and fine transverse wrinkles in the place of stomatiferous bands.

dles and sclerenchymatous tissue are prominent, whereas the peak with a value of 44-50 veins per cm probably represents the abaxial side (Fig. 8B). The strips of vascular bundles and sclerenchymatous tissue have approximately the same thickness, and they are usually considered as ordinary veins (Fig. 13). Even under magnification it is not possible to distinguish which veins belong to vascular bundles and which veins belong to sclerenchymatous tissue. The leaves are amphistomatic.

Cuticles. - Cuticle preparations make it possible to distinguish between narrow and wide veins. 

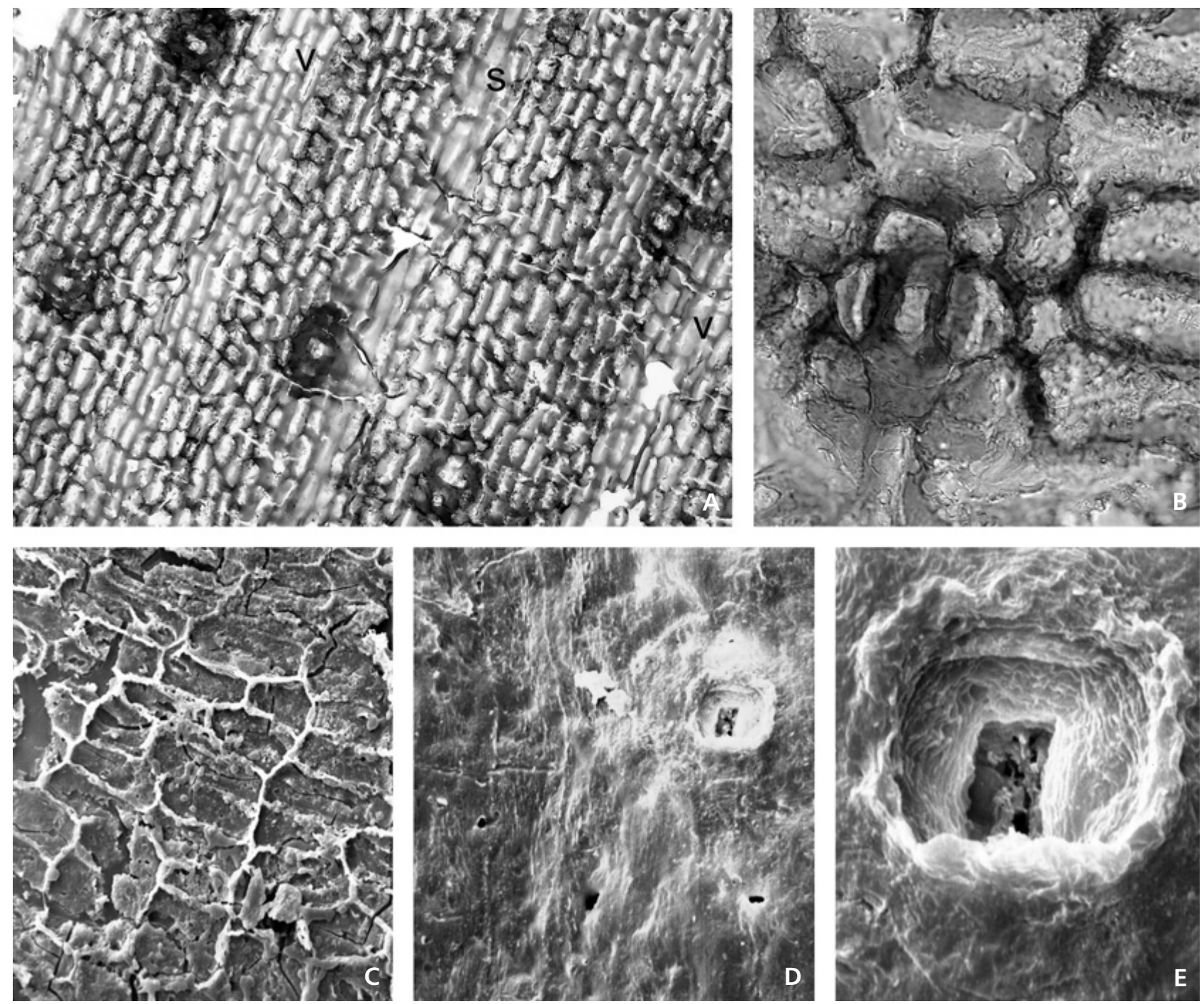

Figure 14. Adaxial epidermis of Cordaites borassifolius (Sternberg) Unger, locality Ovčín near Radnice, Pokrok Mine, Radnice Member, Bolsovian. - A - adaxial epidermis with stomata, v, s - cells of "costal" fields: v - above the vascular bundles, s - above the sclerenchyma strands. Slide No. 353/2, $\times 100$. B - detail from Fig. 14A with a stoma, $\times 400 . \cdot$ C - SEM microphotograph No. 0754. View to inner side with prominent anticlinal cell walls, $\times 200$. $\bullet$ D - SEM microphotograph No. 0758 . View to outer surface with a small stoma, $\times 500 . \bullet E-$ SEM microphotograph No. 0759. Detail of a stoma from Fig. $14 \mathrm{D}, \times 2000$

Adaxial cuticle (Fig. 14): Some adaxial cuticles have bands of cells that are slightly darker than others. The lighter cells are costal bands above vascular strands and are usually $80-160 \mu \mathrm{m}$ wide. The darker intercostal bands are $240-490 \mu \mathrm{m}$ wide with very rarely stomata. Occasionally, the costal band is only $50 \mu \mathrm{m}$ wide and probably represents the epidermis above the sclerenchymatic tissue.

The adaxial cuticle is weakly cutinised, but more prominently than the abaxial cuticle. Cells are the same in both costal and intercostals areas. They are tetragonal and mostly oblong, and less often square or pentagonal to hexagonal in shape. The cells are 30-75 $\mu \mathrm{m}$ long and 20-35 $\mu \mathrm{m}$ wide. Anticlinal walls are slightly or strongly bent. The cells have rounded corners and are parallel to the veins. Stomata are at distances approximately $400 \mu \mathrm{m}$ apart, but not in regular rows (Fig. 14A). The stomatal complex is formed by a pair of sunken elliptical guard cells, two polar subsidiary cells and two lateral subsidiary cells. Pairs of guard cells are 22-26 $\mu \mathrm{m}$ long and 13-16 $\mu \mathrm{m}$ wide. The complex is $60-80 \mu \mathrm{m}$ long and 60-70 $\mu \mathrm{m}$ wide. Polar subsidiary cells are prominent, oval, and $20-30 \mu \mathrm{m}$ in diameter (Fig. 14B). Lateral subsidiary cells are prominent, oblong, with bulging anticlinal walls, $34-50 \mu \mathrm{m}$ long and $16-25 \mu \mathrm{m}$ wide. A square to round outer stomatal cavity is developed above the stomatal pore. The stomatal density is very low, ranging from 6-9 stomata per $1 \mathrm{~mm}^{2}$. The value of the stomatal index varies from 0.7 to 0.9 (Table 1). 

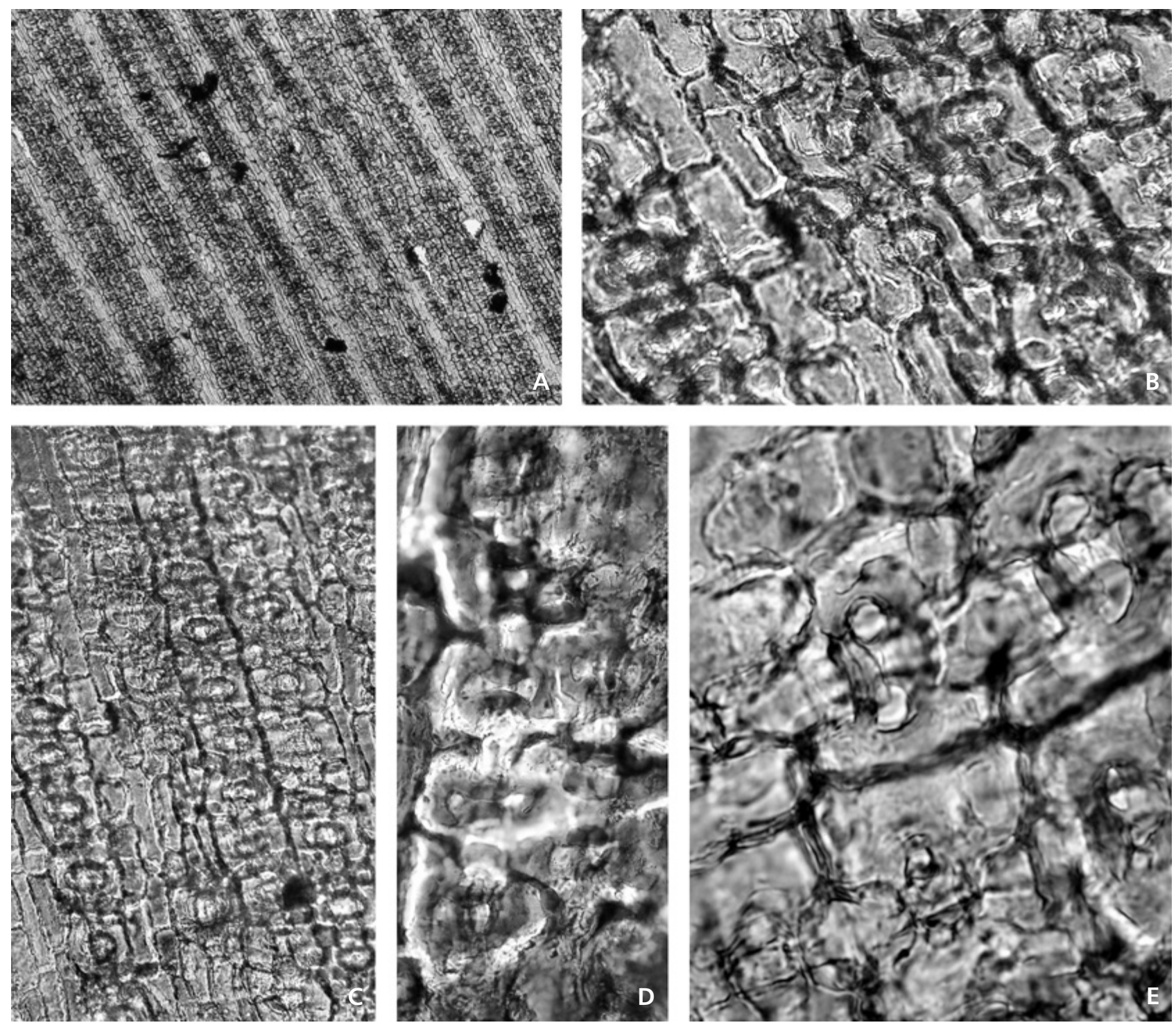

Figure 15. Abaxial epidermis of Cordaites borassifolius (Sternberg) Unger in optical microscopy, locality Ovčín near Radnice, Pokrok Mine, Radnice Member, Bolsovian. $\bullet A-$ cuticle with many stomatiferous and non-stomatiferous bands. It is difficult to judge which non-stomatiferous bands are below the vascular bundles and which are below the sclerenchyma strands. Slide No. 356/3, $\times 50 . \bullet$ B - detail of a stomatiferous band from Fig. $15 \mathrm{C}, \times 400$. - $\mathrm{C}$ - cuticle with stomatal and non-stomatiferous bands. Slide No. 356/3, $\times 200$. $\bullet$ D - stomata with very well preserved crypt viewed under Nomarski interference contrast. Slide No. 355/2, × 400. $\bullet$ E - detail of stomata from stomatiferous band from Fig. $15 \mathrm{~B}, \times 800$.

Abaxial cuticle (Figs 15, 16): The abaxial epidermis is quite different. Stomatiferous bands 75-270 $\mu \mathrm{m}$ wide are separated by narrow, non-stomatiferous (lighter) bands only $30-75 \mu \mathrm{m}$ wide. The wider ones, $45-75 \mu \mathrm{m}$ wide, probably represent the tissue above (or below) the vascular bundles, whereas the thinner ones, 30-45 $\mu \mathrm{m}$ wide, represent the bundles below the sclerenchymatic tissue.

The abaxial cuticle is weakly cutinised compared to the adaxial one. It consists of stomatiferous intercostal bands that are 200-300 $\mu \mathrm{m}$ wide and costal bands that are $60 \mu \mathrm{m}$ wide and formed by three rows of cells (Fig. 15A). All intercostal cells are incorporated into stomatal complexes (Fig. 15B, C). Cells of costal bands are tetragonal, mostly elongate, oblong, 35-110 $\mu \mathrm{m}$ long, and 15-30 $\mu \mathrm{m}$ wide and orientated parallel to the veins. Anticlinal walls are straight or slightly bent. Stomatal complexes comprise a pair of sunken elliptical guard cells, two polar subsidiary cells and two lateral subsidiary cells (Fig. 15D, E). Stomata are orientated parallel to the veins and occur in rows. Pairs of guard cells are 22-26 $\mu \mathrm{m}$ long and 12-16 $\mu \mathrm{m}$ wide (Fig. 16A, B). The stomatal complex is 40-60 $\mu \mathrm{m}$ long and 40-60 $\mu \mathrm{m}$ wide. Polar cells are rounded and 15-20 $\mu \mathrm{m}$ in diameter and are often shared by adjacent stomata. The lateral subsidiary cells are oblong to kidney-shaped, 40-50 $\mu \mathrm{m}$ long, and 20-28 $\mu \mathrm{m}$ wide and about the adjacent lateral cell of the neighbouring stomata in the row. The 
Table 1. Morphological features of cuticles of leaves Cordaites borassifolius and scales and bracts Florinites volkmannii.

\begin{tabular}{|c|c|c|c|c|c|c|}
\hline \multirow{2}{*}{\multicolumn{4}{|c|}{$\begin{array}{l}\text { Species } \\
\text { Organ }\end{array}$}} & Cordaites borassifolius & \multicolumn{2}{|c|}{ Florinanthus volkmannii } \\
\hline & & & & Leaf & Sterile scale & Bract \\
\hline \multirow{13}{*}{$\begin{array}{l}\frac{9}{0} \\
\frac{0}{3} \\
\frac{0}{3} \\
\frac{\pi}{x} \\
\frac{\pi}{0} \\
\frac{0}{4}\end{array}$} & \multicolumn{3}{|c|}{$\begin{array}{l}\text { Difference between stomatiferous and } \\
\text { non-s tomatiferous bands }\end{array}$} & - & - & - \\
\hline & \multicolumn{3}{|c|}{ Cell shape of stomatiferous bands } & Tetragonal - oblong, square & - & - \\
\hline & \multicolumn{3}{|c|}{ Size of stomatiferous cells $(\mu \mathrm{m})$} & $(30-75) \times(20-35)$ & - & - \\
\hline & \multicolumn{3}{|c|}{ Cell shape of non-stomatiferous bands } & Tetragonal - oblong & $\begin{array}{l}\text { Longitudinally tetragonal (oblong, } \\
\text { trapezoidal), pentagonal; base: isodiametric }\end{array}$ & Oblong \\
\hline & \multicolumn{3}{|c|}{ Size of non-s tom atiferous cells ( $\mu \mathrm{m})$} & $(30-75) \times(20-35)$ & $(45-75) \times(12-20) ;$ base: $30-50$ in diameter & $(50-110) \times(10-20)$ \\
\hline & \multirow{4}{*}{ 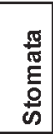 } & \multicolumn{2}{|c|}{ Distribution } & Irregularly dispersed & - & - \\
\hline & & \multicolumn{2}{|c|}{ Density per $1 \mathrm{~mm}^{2}$} & $6-9$ & - & - \\
\hline & & \multicolumn{2}{|c|}{ Stomatal index } & $0,7-0,9$ & - & - \\
\hline & & \multicolumn{2}{|c|}{ length and width of guard cells $(\mu \mathrm{m})$} & $(22-26) \times(13-16)$ & - & - \\
\hline & \multirow{4}{*}{$\begin{array}{l}\text { 응 } \\
\overline{0} \\
\frac{2}{\pi} \\
\overline{0} \\
0 \\
\frac{8}{7} \\
0\end{array}$} & \multirow{2}{*}{$\begin{array}{l}\frac{}{0} \\
\frac{\pi}{0} \\
0\end{array}$} & Num ber and shape & 2; prominent, oval & - & - \\
\hline & & & Size $(\mu \mathrm{m})$ & $20-30$ in diameter & - & - \\
\hline & & \multirow{2}{*}{\begin{tabular}{|c|}
$\frac{\bar{\omega}}{\bar{\omega}}$ \\
$\frac{\bar{\sigma}}{\square}$ \\
\end{tabular}} & Num ber and shape & 2; prominent, oblong & - & - \\
\hline & & & Size $(\mu \mathrm{m})$ & $(34-50) \times(16-25)$ & - & - \\
\hline \multirow{15}{*}{$\begin{array}{l}\frac{0}{0} \\
\frac{0}{3} \\
\frac{0}{0} \\
\frac{\pi}{x} \\
x \\
\frac{0}{x} \\
\frac{0}{4}\end{array}$} & \multicolumn{3}{|c|}{$\begin{array}{l}\text { Difference between stomatiferous and } \\
\text { non-s tomatiferous bands }\end{array}$} & + & - & + \\
\hline & \multicolumn{3}{|c|}{ Cell shape of stomatiferous bands } & Only stomatal complexes & - & Oblong \\
\hline & \multicolumn{3}{|c|}{ Size of stomatiferous cells $(\mu \mathrm{m})$} & - & - & $(40-85) \times(10-20)$ \\
\hline & \multicolumn{3}{|c|}{ Cell shape of non-stomatiferous bands } & Longitudinally oblong (tetragonal) & $\begin{array}{l}\text { Longitudinally tetragonal (oblong, } \\
\text { trapezoidal), pentagonal; base: isodiametric }\end{array}$ & Oblong \\
\hline & & Size o & of non-s tom atiferous cells $(\mu \mathrm{m})$ & $(35-110) \times(15-30)$ & $(45-75) \times(12-20) ;$ base: $30-50$ in diameter & $(50-110) \times(10-20)$ \\
\hline & \multirow{5}{*}{ 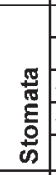 } & Distribution & ibution & Stomatiferous bands & irregularly, only in parts & Single stomatal rows \\
\hline & & \multicolumn{2}{|c|}{ Density per $1 \mathrm{~m} \mathrm{~m}^{2}$} & $350-370$ & $0-40$ & about 300 \\
\hline & & \multicolumn{2}{|c|}{ Stomatal index } & $16-20$ & $<1$ & $4.2-5$ \\
\hline & & \multicolumn{2}{|c|}{ Shape of guard cells } & Eliptical & \pm Oblong & Eliptical \\
\hline & & \multicolumn{2}{|c|}{ length and width of guard cells ( $\mu \mathrm{m})$} & $(22-26) \times(12-16)$ & $(22-28) \times(10-15)$ & $(25-30) \times 22$ \\
\hline & \multirow{5}{*}{ 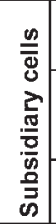 } & \multirow{2}{*}{$\begin{array}{l}\frac{1}{0} \\
0 \\
\end{array}$} & Num ber and shape & 2; rounded & $2-3$; as ordinary cells & 2; oblong \\
\hline & & & Size $(\mu \mathrm{m})$ & $15-20$ in diameter & & $(25-60) \times(12-18)$ \\
\hline & & \multirow{3}{*}{$\begin{array}{l}\overline{\overline{\mathbb{N}}} \\
\overline{\mathbb{Q}} \\
\overline{\mathbb{J}} \\
\end{array}$} & Number and shape & 2; oblong to reniform & $2-3 ;$ as ordinary cells & 2; oblong \\
\hline & & & Size $(\mu \mathrm{m})$ & $(40-50) \times(20-28)$ & & $(40-50) \times(15-22)$ \\
\hline & & & Shape of crypt & $\begin{array}{c}\text { Transverse oval, constricted in the } \\
\text { centre }\end{array}$ & - & Round, of Florin ring shape \\
\hline Trich & iomes: & $\mathrm{s}$ on th & he margin & - & Uniseriate; $100-150 \mu \mathrm{m}$ long & - \\
\hline
\end{tabular}

outer stomatal cavity is developed transversely across the lateral subsidiary cells. It is elongate and constricted in the central part (Fig. 15D, E, 16C-F). Stomatal complexes are arranged in rows; with three to six rows forming a band. The stomatal density is $350-370$ per $1 \mathrm{~mm}^{2}$. The value of the stomatal index varies from 16 to 20 (Table 1 ).

Remarks. - A detailed description of material later assigned to $C$. borassifolius by Unger 1850 was made by Corda (1845), who described large specimens from Svinná in the Radnice Basin (Fig. 7) under the name Flabelaria borassifolia. He also studied the anatomy of partly carbonised stems and cuticles of leaves. Corda (1845) described the typical Cordaites borassifolius venation as narrow and wide alternating veins. A few years later, Unger (1850) erected the name Cordaites, and the species Cordaites borassifolius was selected as the type of this genus. Unger's definition was based on both leaf form and stem anatomy.

Zeiller (1886, p. 628) excluded from Cordaites borassifolius leaves figured by Ettingshausen (1852, pl. 5, fig. 5). According to Zeiller (1886), the veins are varied and he suggested that Ettinghausen's material instead belonged to Cordaites principalis (Germar) Geinitz. This opinion was also accepted by Crookall (1970). However, Ettingshausen's (1852) specimen comes from Stradonice (Hýskov relict), which is relatively close to Svinná, the type area of C. borassifolius. In fact, the horizon is practically the same as the unit from which the holotype of $C$. borassifolius was collected. The venation pattern can vary, as we know from the $C$. borassifolius sample population from the Ovčín locality. Unfortunately, some cuticles prepared from a $C$. borassifolius specimen from Stradonice (Naturhistorisches Museum, Wien) are strongly corroded, which does not allow comparison with the holotype of $C$. borassifolius. The cellular structures of the adaxial epidermis of $C$. borassifolius were already studied by Corda (1845, pl. 24, figs 2, 3). He observed leaves without maceration and correctly interpreted the alternating thin and thick veins, cellular shape and orientation and also the stomata distribution. However, he was unable to observe details of the stomatal structure.

Florin (1931, p. 499, fig. 105a) figured abaxial cuticles from a specimen determined as Cordaites sp. 1, which origi- 

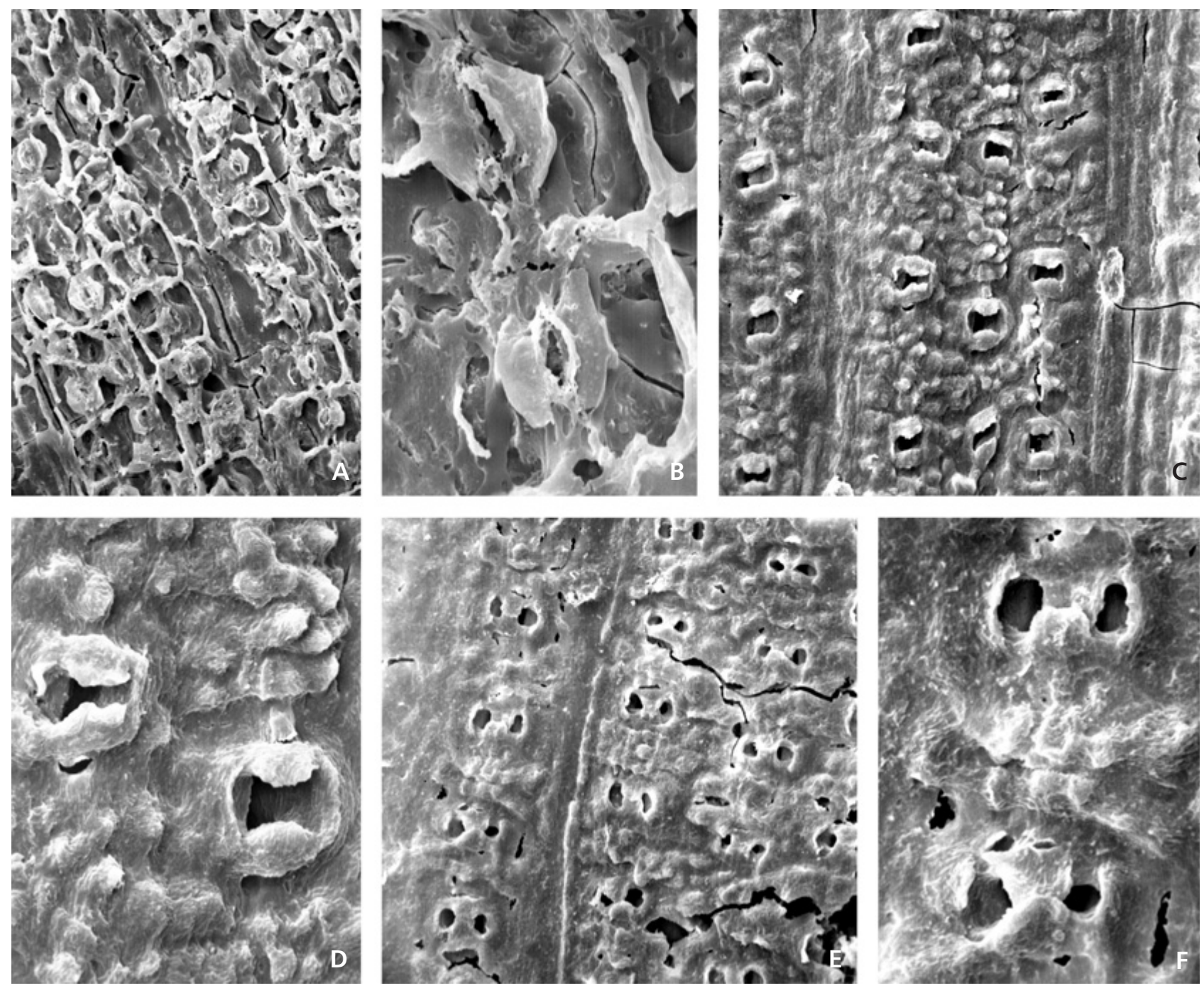

Figure 16. Abaxial epidermis of Cordaites borassifolius (Sternberg) Unger under SEM, locality Ovčín near Radnice, Pokrok Mine, Radnice Member, Bolsovian. • A - view to inner surface with stomatal and non-stomatiferous bands. SEM microphotograph No. 0749, × 200. • B - detail from Fig. 16A with two stomata. The guard cells are well visible. SEM microphotograph No. $0751, \times 1000 \cdot \bullet \mathrm{C}$ - view of outer surface with stomata. Note that the crypt is not fully developed, and only two papillae projections per stoma are developed. SEM microphotograph No. 0761, $\times 400$. $・ \mathrm{D}-$ detail from Fig. $16 \mathrm{C}$ with two stomata. SEM microphotograph No. $0762, \times 1000$. $\bullet$ E - view of outer surface with stomata. The crypt is well developed. SEM microphotograph No. $0752, \times 400 . \bullet F-$ detail from Fig. E with two stomata. SEM microphotograph No. 0753, $\times 1000$.

nated from the Radnice Member (Bolsovian) of the Rakovník locality, Czech Republic, and from another specimen he referred to as Cordaites sp. 2 from New Brunswick (Westphalian D), Canada. The stomatal complexes of both specimens are structurally similar; two large lateral subsidiary cells and two small polar subsidiary cells. They only differ in the shape of these cells. Both species have a crypt across the guard cells as in $C$. borassifolius. However, they differ in the shape of the subsidiary cells and therefore their mutual identity is questionable. These samples differ from our material in the shape of the subsidiary cells and the distribution of stomata. Stomata of Florin's (1931) Cordaites sp. 1 are arranged in simple stomatal rows, whereas stomata of Cordaites borassifolius are in multiple rows in bands.
Barthel (1964) described Cordaites cuticular morphotype 6 from the Autunian of the Döhlen Basin as having a transverse crypt across the guard cells, which is very similar to the Bohemian species Cordaites borossifolius (Sternberg) Unger from the Radnice Member. Barthel compared this species with Florin's (1931) Cordaites sp. 1 from the Bolsovian of Rakovník.

Fertile organ of indeterminate sex (possibly female). Two types of strobili were found at the Ovčín localities. We consider the more robust form to be the female fertile organ even though seeds have not yet been found in connection with it [determined as Cordaitanthus ovatus (Lesquereux) Ignatiev \& Meyen], and the smaller form as the 

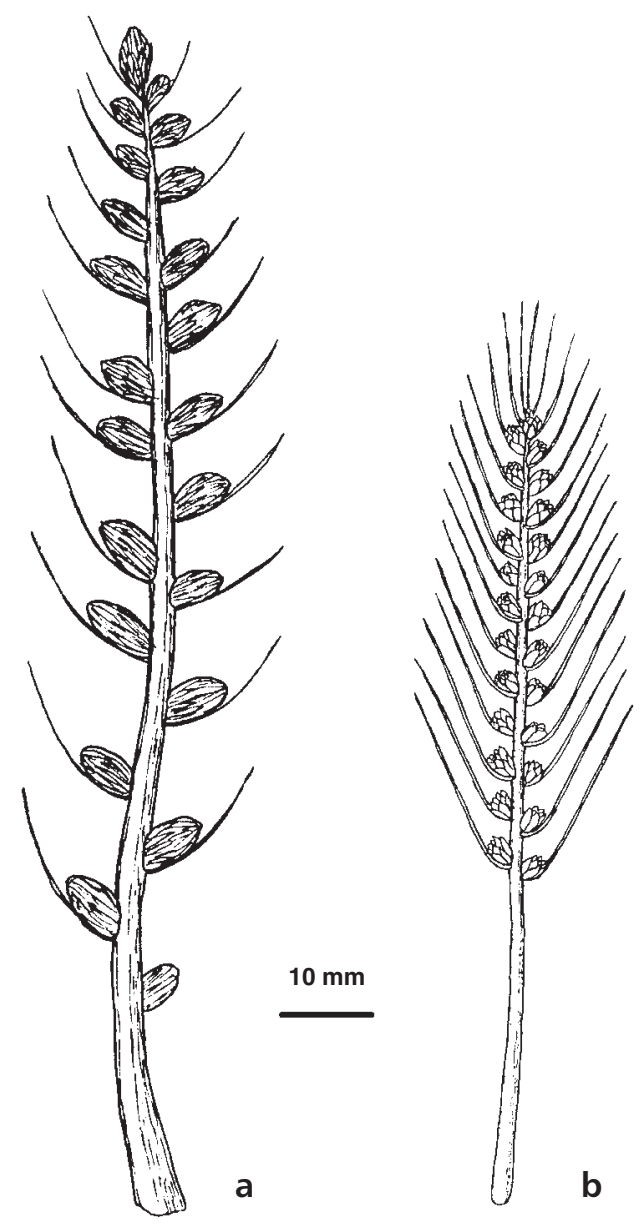

Figure 17. Fertile organs of Cordaites borassifolius (Sternberg) Unger, - a - probably female cone Cordaitanthus ovatus (Lesquereux) Ignatiev \& Meyen, $\bullet \mathrm{b}-$ male cone Florinanthus volkmannii (Ettingshausen) comb. nov. Scale bar $=10 \mathrm{~mm}$.

male fertile organ of the form refereable to as Florinanthus volkmannii (Ettingshausen) Šimůnek, Opluštil \& Drábková comb. nov.

\section{Genus Cordaitanthus Feistmantel, 1876}

Type species. - Cordaitanthus communis Feistmantel, 1876

Basionym. - Antholithes triticum Andrae, 1864, pp. 174, 175, pl. 4 , fig. 6 .
Proposed lectotype. - Cordaitanthus communis Feistmantel, 1876, pl. 12, fig. 4.

Remark. - Feistmantel (1876) on pl. 12, figs 1-4, figured 4 syntypes of his Cordaitanthus communis. They come from different localities (Stradonice, Kralupy nad Vltavou, Nýřany) and evidently they belong to different species. We propose to choose Feistmantel's (1876) specimen figured in his pl. 12, fig. 4, as a lectotype of the genus Cordaitanthus. Feistmantel (1876) refigured Andrae's (1864) Antholithes triticum from pl. 4, fig 6. Antholithes triticum is an earlier nomenclatural synonym of Cordaitanthus communis and takes priority over Cordaitanthus communis. Therefore Cordaitanthus triticus becomes the effective type species of Cordaitanthus.

Diagnosis of the genus Cordaitanthus. - Original diagnosis of Ignatiev \& Meyen, 1989. Primary axis elongate, up to $300 \mathrm{~mm}$ long, and $15 \mathrm{~mm}$ wide. Axillary bract complexes borne on both sides of the axis, arranged in juxtaposition or alternate, and composed of helically arranged scaly appendages. Bracts ranging from scaly to needle-shaped, up to $33 \mathrm{~mm}$ long. The bracts frequently have become turned down and the fertile organ looks as if it lacks bracts.

\section{Cordaitanthus ovatus (Lesquereux) Ignatiev \& Meyen, 1989}

Figures 17a, 18A-F

1880 Cordaianthus ovatus Lesquereux, p. 545, pl. 76, fig. 5, 5a.

1989 Cordaitanthus ovatus Lesquereux. - Ignatiev \& Meyen, p. 335.

Type locality. - Cannelton, Pennsylvania, U.S.A.

Type horizon. - Westphalian D.

Description. - Based on material from OE1, 2, and 3, West Bohemian Museum, No. F 08054 and F 07986A. Fragments of primary axes up to $90 \mathrm{~mm}$ long (Fig. 18A) and typically $3 \mathrm{~mm}$ wide. The axillary complexes are borne on both sides of the axis somewhat irregularly and alternately. They are closely arranged in the terminal part and sparsely

Figure 18. A-F - Cordaitanthus cf. ovatus (Lesquereux) Ignatiev \& Meyen. Probably the female fertile organ of Cordaites borassifolius. Locality Ovčín near Radnice, Radnice Member, Bolsovian. Coll. West Bohemian Museum, Plzeň, $\times 1$. C - detail from Fig. 18B, $\times 3$. D - detail from Fig. $18 \mathrm{~A}, \times 5$. E, F - cone fragments, E - locality Ovčín, D1; $100 \mathrm{~mm}$ above coal, No. F 08054, × 2; F- locality Ovčín, No. F 02193, × 3. • G-K - seeds Cardiocarpus annulatus (Sternberg) Lesquereux that probably belong to Cordaites borassifolius; coll. West Bohemian Museum, Plzeň. G - locality Ovčín, D3 base, No. F 08045, × 3; H - locality Ovčín, D 2 base, No. F 07986B, × 3; I - locality Ovčín, D 2 base, No. F 07986A, × 3. J, K - imprint and counterpart of Sternberg's type specimens of Cardiocarpus "Carpolites" annulatus Sternberg, possible seed of Cordaites borassifolius. Locality Radnice, coll. National Museum, Prague, Nos. E 1207 and 1208, × 3 . 
Zbyněk Šimůnek et al. • Cordaites from the Radnice Basin (Bolsovian)

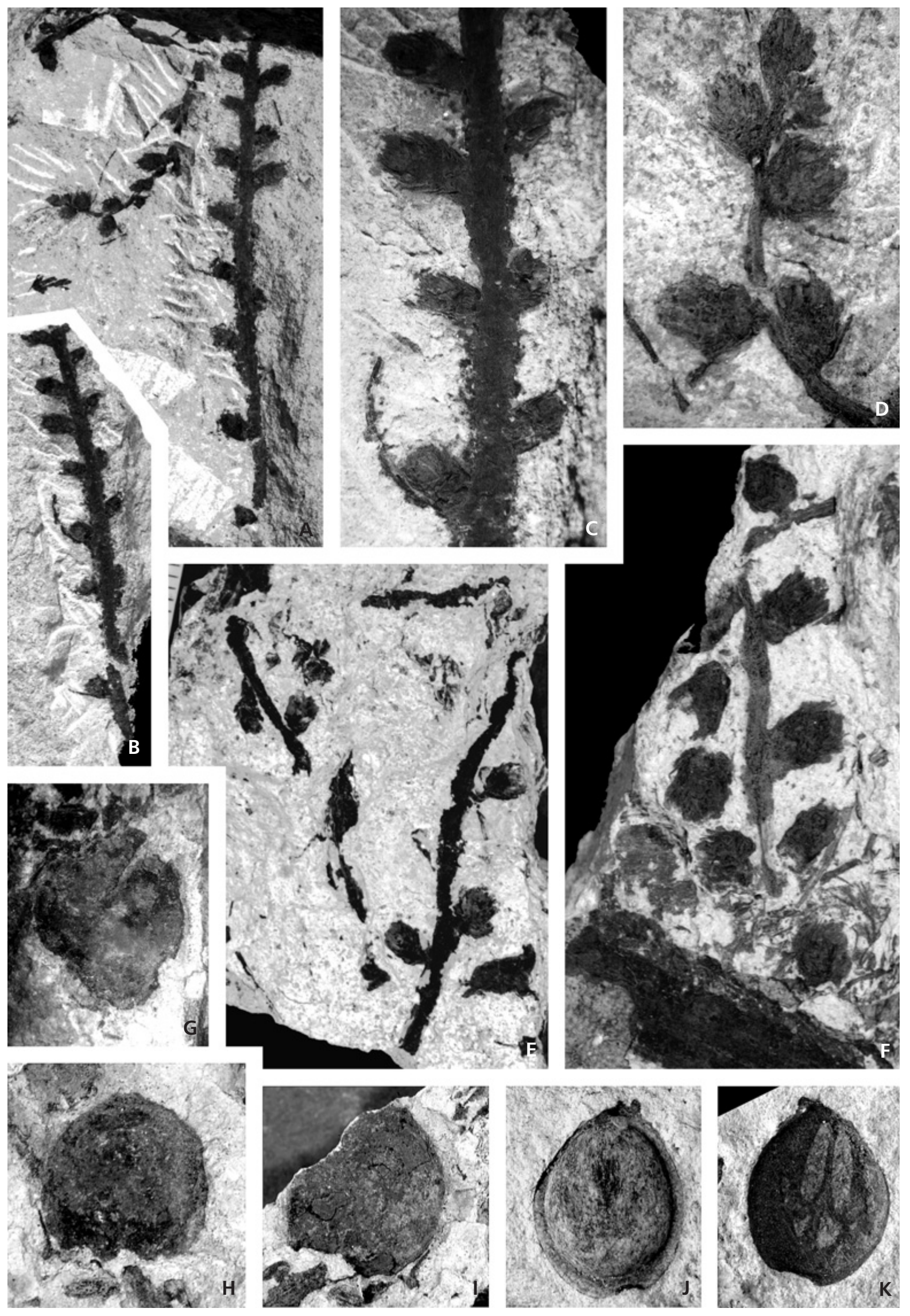


in the basal part of the fertile organ. Axillary buds are formed by a small secondary axis and helically arranged scales. The shape, dimension and number of scales per bud are usually difficult to determine due to poor preservation. The buds are 6-9 $\mathrm{mm}$ long and $4-6 \mathrm{~mm}$ wide. Their apex is conical (Fig. 18D). The shape of the scales is probably lanceolate. The bracts are 0.4 to $1 \mathrm{~mm}$ wide, $10-15 \mathrm{~mm}$ long, and turned upwards (Fig. 18C).

Remarks. - The specimens found at Ovčín OE1, 2, and 3 fit Lesquereux's description of Cordaitanthus ovatus. It is more robust than the male fertile organ Florinanthus volkmannii (Fig. 17B), and for this reason we consider it to be the female fertile organ of Cordaites borassifolius, although direct evidence is lacking. The buds of Cordaitanthus ovatus are 6-9 mm long and 4-6 mm wide, whereas those of Florinanthus volkmannii are $2-4 \mathrm{~mm}$ long and only $1.5-3 \mathrm{~mm}$ wide. The sterile scales of $C$. ovatus are lanceolate, whereas those of $F$. volkmannii are spatulate. Only the small inner scales of $F$. volkmannii are lanceolate.

\section{Seeds}

(Figs 18G-K, 19, 20A-F)

Sternberg (1820) figured 12 seeds of the genus "Carpolites" from Radnice, and some of them could belong to cordaitalean plants. Of these seeds, Carpolites (Cardiocarpus) annularis Sternberg, 1820 (Lesquereux, 1884), Carpolites (Cardiocarpus) regularis Sternberg, 1820 (Lesquereux, 1880), and perhaps Carpolites (Cardiocarpus) retusum Sternberg, 1820 (Newberry, 1873) are most similar to the seeds found at Ovčín. Because Sternberg (1820) did not describe them, all of these names are invalid as nomina nuda. We believe that the shape and dimensions of material from Ovčín fit best to the name Carpolites (Cardiocarpus) annularis and therefore we add its description and diagnosis to validate this name.

Cardiocarpus annularis (Sternberg) Lesquereux, 1880 Figures 18G-K, 19, 20A-F

1820 Carpolites annularis Sternberg, pl. 7, fig. 15.

1825 Carpholites annularis Sternberg, tent. 40.

1884 Cardiocarpus annularis (Sternberg). - Lesquereux, p. 814 , pl. 110 , figs $28-30$.

Holotype. - National Museum, Prague, No. E 1207, Stern- berg, pl. 7, fig. 15, refigured here on Fig. 18J; counterpart E 1208 is figured here on Fig. 18K.

Diagnosis. - Seeds small, round to oval, surrounded by narrow rim (sarcotesta), surface of sclerotesta smooth (occasionally crumpled). Epidermis composed of polygonal cells.

Description of the holotype (Fig. 18J). - The seed is oval, $13 \mathrm{~mm}$ long and $11 \mathrm{~mm}$ wide, the sarcotesta rim is widest near the base $>1 \mathrm{~mm}$ and tapers near the apex to $0.7 \mathrm{~mm}$.

Description. - Seeds are small wingless, platyspermic, round or oval, and in their terminal parts a little tapered. The inner sclerotesta layer and outer sarcotesta layer are preserved (Fig. 18I-K, 19D, E). The sclerotesta consists of thick-walled sclerotic cells and the sarcotesta of fleshy cells. The seeds are 10-11 mm long and 9-11 mm wide. Most of the seed area is occupied by sclerotesta, while the sarcotesta forms a narrow rim less than $0.7 \mathrm{~mm}$ thick.

Cuticles. - Two types of cuticles have been recovered from the SE material. The most common is a thick-walled cuticle with randomly orientated polygonal cells, 40-90 $\mu \mathrm{m}$ long and 30-50 $\mu \mathrm{m}$ wide (Fig. 19H, I). The anticlinal walls are very thick and prominent (Fig. 20B). In some parts, the cells tend to be elongated, tetragonal, parallel orientated (Fig. 19F, G), 40-110 $\mu \mathrm{m}$ long and 20-40 $\mu \mathrm{m}$ wide. Only one stomata-like oblong aperture (Fig. 19J, $\mathrm{K}), 17 \mu \mathrm{m}$ long and $12 \mu \mathrm{m}$ wide, surrounded by 5 very small subsidiary cells was observed. Guard cells are not present.

The second type consists of two thin-walled layers of cells (Fig. 20D-F). The cells are polygonal, 35-100 $\mu \mathrm{m}$ long and $35-50 \mu \mathrm{m}$ wide. The anticlinal walls are very thin (Fig. 20F).

Remark. - It is not exactly known from which part of the seed a particular cuticular type came from, however, we presume that the thick-walled cuticle covered the sclerotesta and the thin-walled cuticle covered the sarcotesta, because this layer is fleshy and its cuticle is usually thinner than cuticle of the sclerotesta. Dispersal of these wingless seeds was limited and resulted in them being clustered on the ground at the base of the tree as they were found in Ovčín locality.

Figure 19. Seeds of Cordaites borassifolius comparable to Cardiocarpus "Carpolites" annulatus (Sternberg) Lesquereux. Locality Excavation Ovčín 2006, base 1D-2. • A - accumulation of seeds together with Cordaites borassifolius leaves, $\times 1$. $\bullet$ B - detail from Fig. 19A, $\times 2$. $\bullet$ C, D - detail from Fig. 19A. Most of the seed body encompass sclerotesta and only a thin rim sarcotesta. $\times 3$. $\bullet$ E - a seed adpression from excavation "Ovčín", $\times 3$. - F-K - seed cuticle probably from the sclerotesta layer from seeds on Fig. 19A. F, G -cuticle with longitudinally oriented cells, slide No. 469/2, F $\times 100$, $\mathrm{G} \times 200 ; \mathrm{J}, \mathrm{I}$ - cuticle with randomly oriented cells, slide No. 469/1, H × 100, I × 200; J, K - stomata-like structure, slide No. 469/3. J × 400, K × 200. 
Zbyněk Šimůnek et al. • Cordaites from the Radnice Basin (Bolsovian)
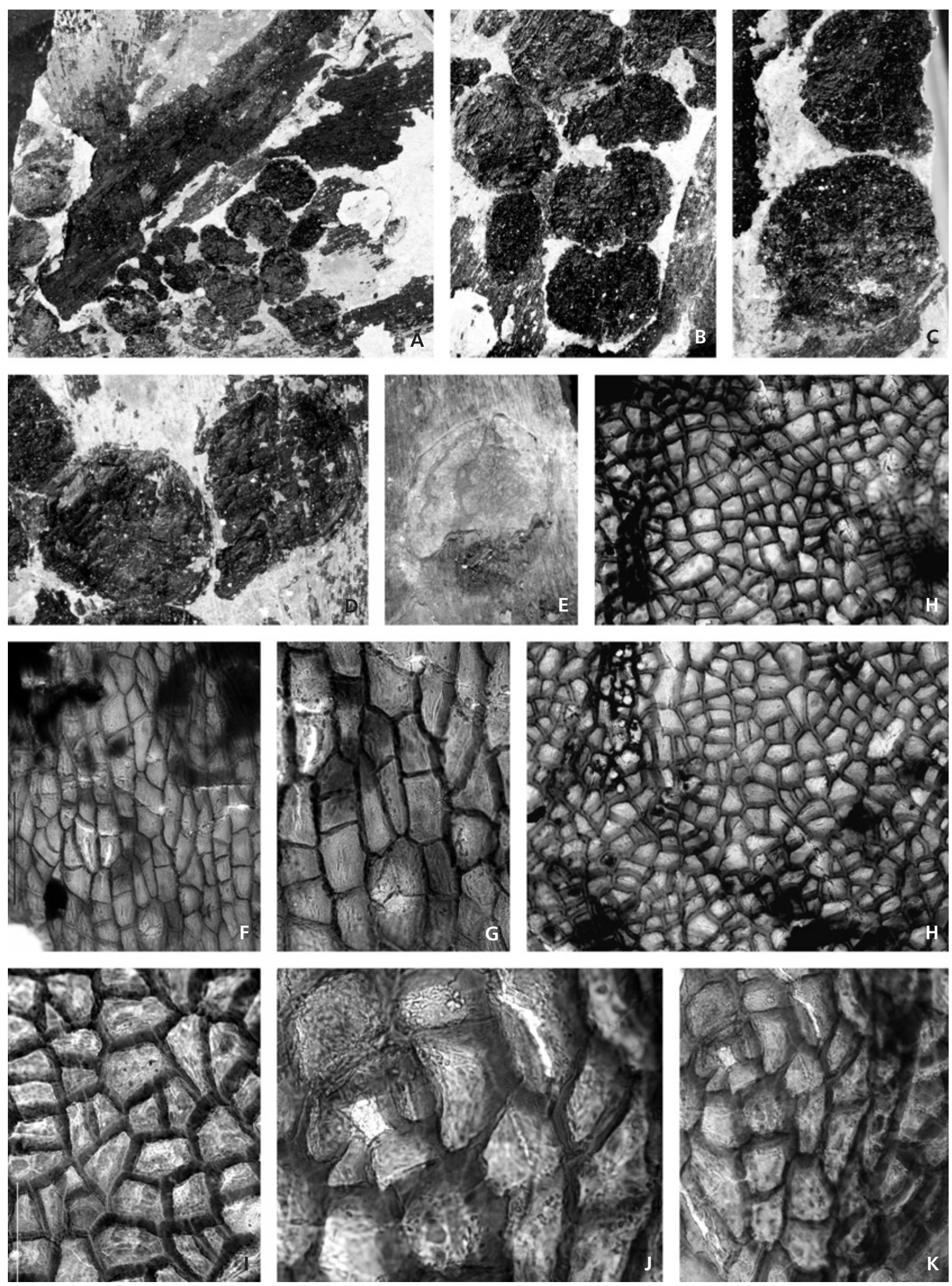


\section{Male fertile organ}

\section{Genus Florinanthus Ignatiev \& Meyen, 1989}

Type species. - Florinanthus concinnus (Delevoryas) Ignatiev \& Meyen, 1989.

General characteristics. - The primary axis arising from the axil of a leaf is more or less bilaterally symmetrical. The medullated stele of the primary axis gives off traces to four rows of secondary shoots and their subtending bracts. Auxillary bract complexes (secondary shoots) are arranged in a compact helix and consist of a short axis on which there are numerous (up to 100) scaly appendages. Up to 40 terminal scales are fertile. Sporangiophores are unbranched or apically forked once. Each sporangiophore (fertile scale) is terminated by a maximum of 6 microsporangia (pollen sacs), which are fused at the base. They are elongate with a longitudinal dehiscent slit and contain monosaccate pollen of the Florinites-type (Ignatiev \& Meyen 1989).

Florinanthus volkmannii (Ettingshausen) comb. nov. Figures 17b, 21-29

1852 Calamites Volkmanni, Ettingshausen, pp. 5, 6, pl. 5, figs 1-3 (non fig. 4, non pl. 6, figs 1 and 2).

1911 Cordaianthus Volkmanni Ettingshausen. - Kidston, p. 236.

1968 Cordaianthus sp., Němejc, pl. 24, fig. 3.

1970 Cordaitanthus volkmanni Ettingshausen. - Crookall, p. 828, text-fig. 239 (syntypes) (non pl. 158, fig. 4).

Specimina excludenda. -

1886 Cordaianthus Volkmanni Ettingshausen. - Zeiller, p. 637 , pl. 94 , fig. 6 .

1917 Cordaianthus Volkmanni Ettingshausen. - Seward, p. 267 , fig. $480 \mathrm{~B}$.

1963 Cordaianthus volkmani (Ettingshausen) Zeiller. Lee, p. 160, pl. 13, fig. 7.

1970 Cordaitanthus volkmanni Ettingshausen. - Crookall, p. 828 , pl. 158 , fig. 4 .

Syntypes. - Calamites Volkmanni, Ettingshausen (1852), pl. 5, figs 1-3.
Type locality. - Stradonice near Beroun (Hýskov relict).

Type horizon. - Kladno Formation, Radnice Member, Radnice group of seams, Whetstone Horizon, Carboniferous, Bolsovian.

Description. - Primary axis elongate, up to $100 \mathrm{~mm}$ long, and about 1 to $1.5 \mathrm{~mm}$ wide (Fig. 17b). It bears 4 rows of axillary secondary shoots that are subtended by very long, narrow bracts, arching more or less towards the axial tip. Axillary bract complexes in two paired rows (Fig. 21) seem to be only in two rows in the impression/compression state (Fig. 23B). The flattened axis could be taphonomic. The two buds on the right side are bent towards the axis and their ramification is not clear, whereas the ramification on the left side is clearly visible. The lower and upper buds arise from the upper side of the axis, whereas the middle bud arises from the lower side. The divergent angle of each pair of rows of axillary bract complexes (orthostichies) is estimated to be $30-40^{\circ}$. The bracts are usually $0.5 \mathrm{~mm}$ wide and up to $25 \mathrm{~mm}$ long. Their apex is sharp. The buds (Fig. 22A) are relatively small and wide, usually 2.8-3.5 mm long and 2-3 mm wide (Ovčín - Přívětice, mine Pokrok). The sterile and fertile scales are of different shapes and sizes. There are only a few scales per bud, usually 20-30. The outer scales (Fig. 22c, 24D) are spatulate up to $3 \mathrm{~mm}$ long and $1.8 \mathrm{~mm}$ wide. The scales near the centre (Fig. 22B, 24B) are smaller, lanceolate, with a round apex 2-2.5 $\mathrm{mm}$ long and up to $1.4 \mathrm{~mm}$ wide. The third type of scale (Fig. 22D, 24C) is small and lanceolate with a sharp apex, 1.5 to $2 \mathrm{~mm}$ long and 0.8 to $1.1 \mathrm{~mm}$ wide. These scales are situated in the very centre of the bud and were probably fertile. The schematic cross section of a bud is illustrated in Fig. 22B. However, pollen sacs have not yet been found, but accumulations of prepollen grains have been discovered stuck to such scales (National Museum, E 5896). Small trichomes, 100-150 $\mu$ m long, grow out of the scale margins in their terminal parts.

Cuticle of the scale (Figs 25, 26). - The adaxial and abaxial cuticles are very similar and the epidermis shows an elongate cellular structure (Figs 25B, C, 26E, G). Individual cells are oblong, trapezoidal or elongate pentagonal and are 45-75 $\mu \mathrm{m}$ long, and 12-20 $\mu \mathrm{m}$ wide. Near the base of the scale (Fig. 25E), the cells are more or less isodiametric in

Figure 20. Seed cuticles of Cardiocarpus "Carpolites" annulatus (Sternberg) Lesquereux belonging probably to Cordaites borassifolius. Loc. Excavation Ovčín 2006, base 1D-2. A. - C. Cuticle of sclerotesta in SEM. $\bullet$ A - longitudinally oriented cells, $\times 100, \bullet$ B, C - inner view to sclerotesta cuticle with randomly oriented cells. Note the prominent thick anticlinal cell walls. B $\times 400, \mathrm{C} \times 100$. $\bullet \mathrm{D}, \mathrm{E}-$ cuticle of sarcotesta. It is formed by two layers of cells. Note the very thin-walled, randomly oriented polygonal cells. Slide No. 469/5, D $\times 150$, E $\times 300$. $\bullet$ F - inner view to the sarcotesta cuticle in SEM. Note the very thin anticlinal walls of polygonal cells, $\times 250 . \bullet \mathrm{G}, \mathrm{H}-$ trunk or twig surfaces of Cordaites borassifolius, coll. West Bohemian Museum, Plzeň. $\mathrm{G}-\mathrm{A}$ fragment of trunk with a twig, loc. Ovčín A1; base, $\times 1 ; \mathrm{H}-$ a fragment of a twig with transition between surface and "Artisia" type preservation. Locality Ovčín (Sternberg) C3, × 0.5. 
Zbyněk Šimůnek et al. • Cordaites from the Radnice Basin (Bolsovian)
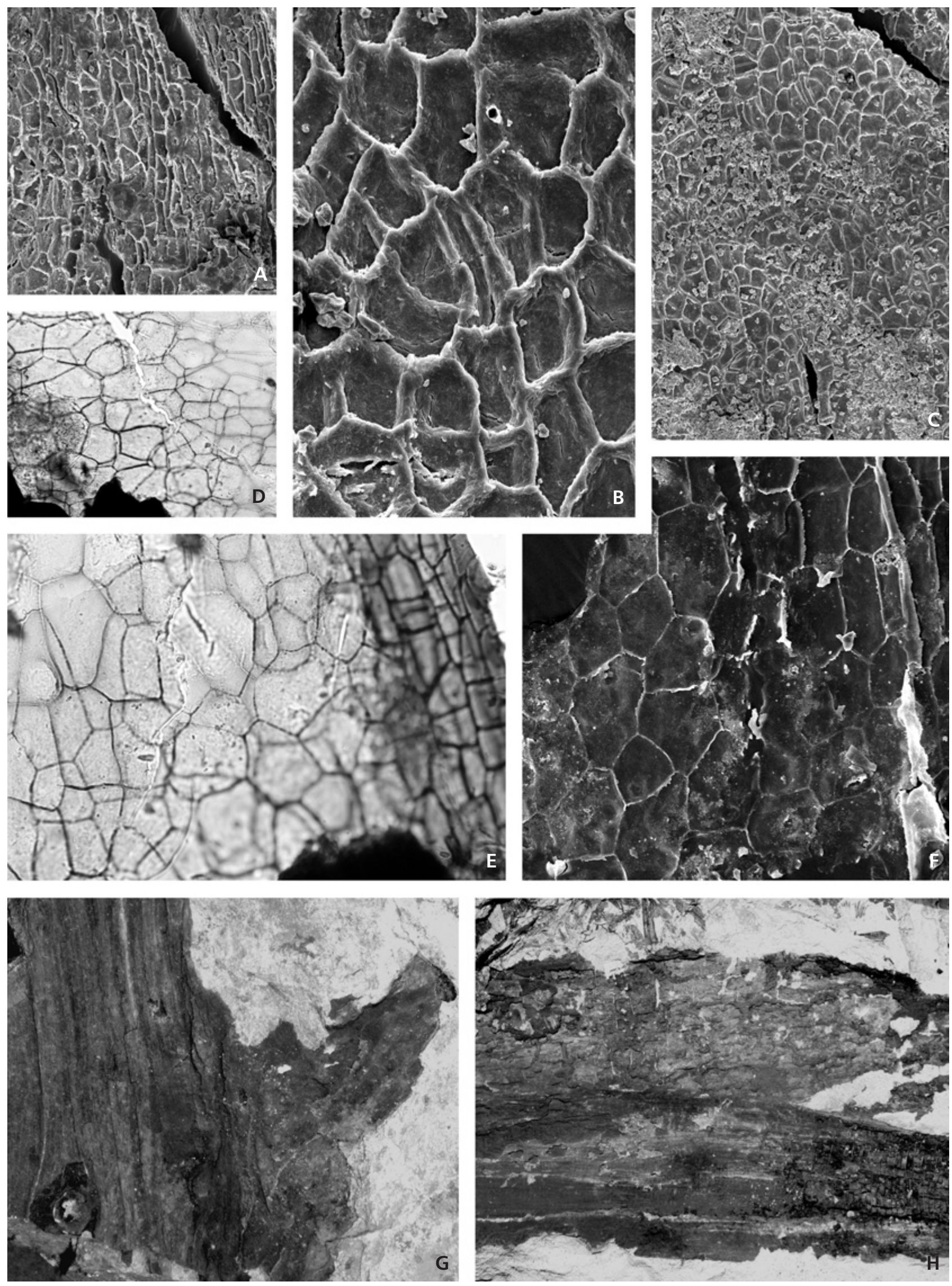


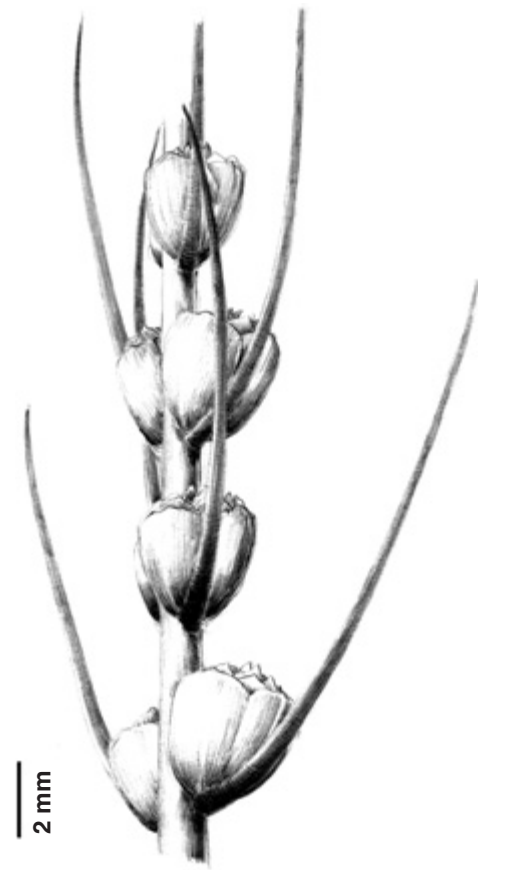

Figure 21. Part of the male cone Florinanthus volkmannii (Ettingshausen) nov. comb. (reconstruction by J. Svoboda), scale bar $=2 \mathrm{~mm}$.
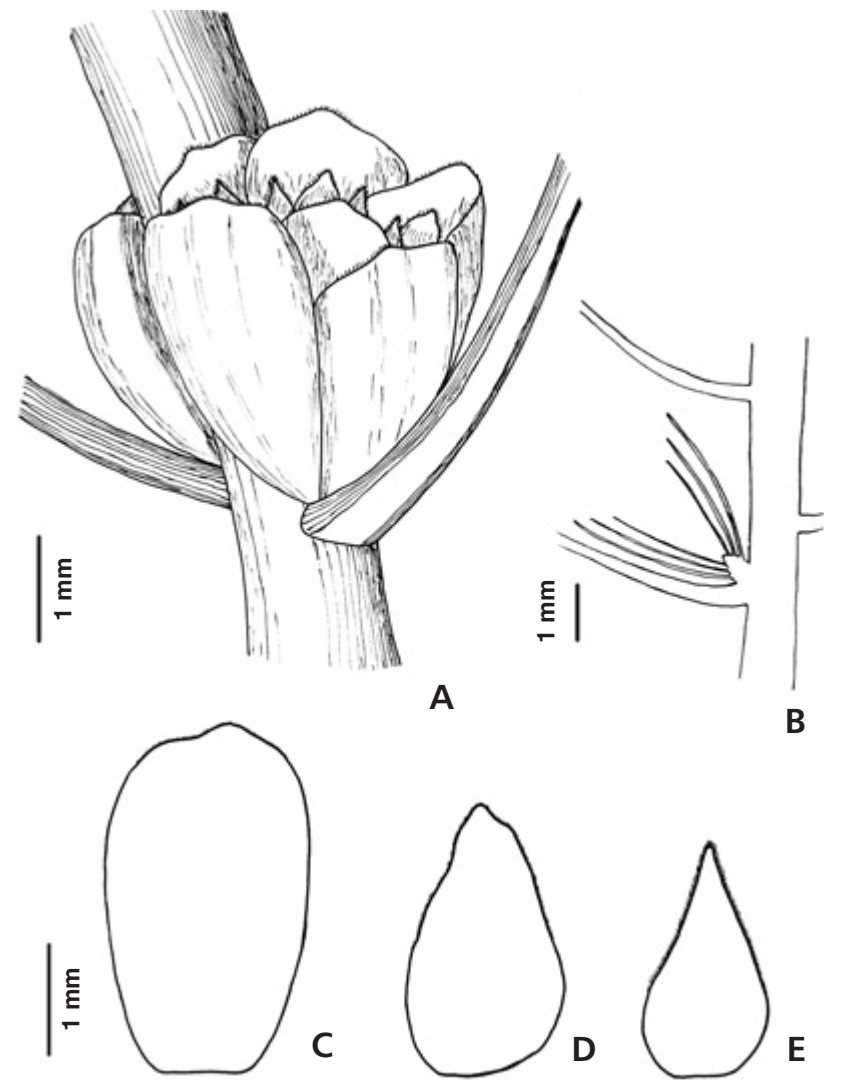

Figure 22. Florinanthus volkmannii (Ettingshausen) comb. nov. - reconstruction of a bud (A) and its section (B), scale bars $=1 \mathrm{~mm}$. - $\mathrm{C}-\mathrm{E}$ - sterile scales of the cone with different shape, scale bar = $1 \mathrm{~mm}$.
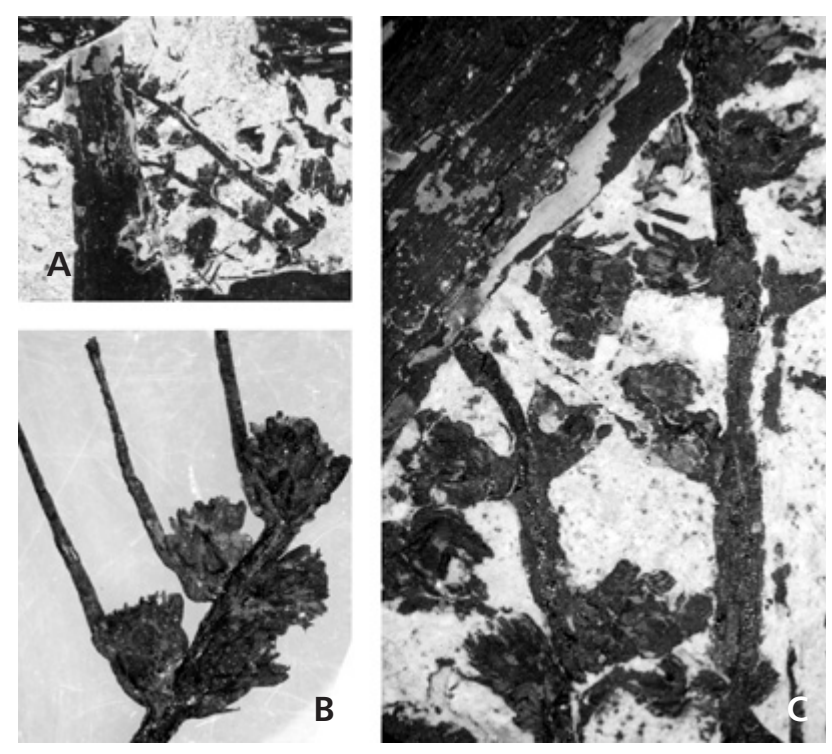

Figure 23. Florinanthus volkmannii (Ettingshausen) comb. nov., a male fertile organ of Cordaites borassifolius. Loc. Ovčín near Radnice, Pokrok Mine, Radnice Member, Bolsovian; National Museum in Prague, No. 5896. - A - a specimen with Florinanthus cones and Cordaites borassifolius leaves, $\times 1$. $\bullet \mathrm{B}-$ isolated part of Florinanthus cone from Fig. 23A with 5 fertile "buds" and bracts, Slide No. 416/22, $\times 5$. $\bullet$ C - a detail of two cones from Fig. $23 \mathrm{~A}, \times 5$.

shape, randomly orientated and $30-50 \mu \mathrm{m}$ in diameter. The anticlinal cell walls are straight or slightly bent. The stomata are irregularly dispersed on the cuticle (Fig. 25A, B), but it is not known whether they occur on the adaxial or abaxial cuticle. The stomatal complex is simple, consisting of two guard cells surrounded by 4 to 6 subsidiary cells of the same shape as the ordinary epidermal cells. The visible part of the guard cells is somewhat oblong, 22-28 $\mu \mathrm{m}$ long, and $10-15 \mu \mathrm{m}$ wide. The stomatal density varies from none to 40 stomata per $1 \mathrm{~mm}^{2}$ (measured on $0.1 \mathrm{~mm}^{2}$ area) and the stomatal index is less than 1 . Three rows of trichomes are prominent along the scale margin (Fig. 26A, C, D). They are simple, uniseriate, $100-150 \mu \mathrm{m}$ long and 12-20 $\mu \mathrm{m}$ wide (Fig. 25F), and are formed by 3 to 4 barrel-shaped cells and a terminal cell that is elongate triangular in shape arising almost perpendicular to the other cells. The anticlinal cell walls are moderately developed. The periclinal walls are slightly arched and bear papillae and small depressions. Papillae are small with a bluntly pointed tip, their base is elliptical, 25-35 $\mu \mathrm{m}$ long and 10-15 $\mu \mathrm{m}$ in height (Fig. 26H). Small elliptical depressions of unknown function are seen on some periclinal walls (Fig. 26H). These depressions are 12-18 $\mu \mathrm{m}$ long and 4-7 $\mu \mathrm{m}$ wide (Fig. 26B, E). They appear to be small stoma and represent true holes, $7 \mu \mathrm{m}$ long and $2 \mu \mathrm{m}$ wide, through the cuticle. They are transversely orientated to the cell direction.

Cuticle of the bract (Figs 27, 28A-E). - The adaxial and abaxial cuticles are difficult to distinguish from one anot- 
her, but the adaxial cuticle probably has less stomatal rows (Fig. 27D). The presumed abaxial cuticle with 4 stomatal rows is illustrated in Fig. 27B. The normal epidermal cells are oblong with straight, thin anticlinal walls, 50-110 $\mu \mathrm{m}$ long and 10-20 $\mu \mathrm{m}$ wide (Fig. 27C, D). The stomata are evenly spaced, between 50 to $150 \mu \mathrm{m}$ apart, within a stomatal row. Stomatal rows are 120-200 $\mu \mathrm{m}$ apart. The stomatal complex is formed by a pair of guard cells that are 25-30 $\mu \mathrm{m}$ long and ca $22 \mu \mathrm{m}$ wide, two bean-shaped lateral subsidiary cells and two square to oblong polar subsidiary cells, similar to normal epidermal cells. The guard cells are sunkenand elliptical (Fig. 28D). The outer stomatal crypt is round, 20-25 $\mu \mathrm{m}$ in diameter (Figs 27A, F, 28A, E), and resembles the Florin rings of younger conifers (Buchholz \& Gray 1848) seen in the Podocarpaceae (Stocky et al. 1992, 1995, 1998) and Araucariaceae (Stockey \& Atkinson 1993). Not including the polar cells, the stomatal complex is $48-55 \mu \mathrm{m}$ wide and 40-50 $\mu \mathrm{m}$ long (the stomatal complex with polar cells would be up to $150 \mu \mathrm{m}$ long). The lateral cells are 40-50 $\mu \mathrm{m}$ long and 15-20 $\mu \mathrm{m}$ wide, the polar cells are 25 to $60 \mu \mathrm{m}$ long and $12-18 \mu \mathrm{m}$ wide (Table 1 ).

Cuticle of the strobilar axis (Figs $27 \mathrm{H}, 28 \mathrm{~F}-\mathrm{H})$. - The cuticle is very thick, up to $30 \mu \mathrm{m}$ (Fig. 28F). The outer surface is nearly flat, whereas the inner surface has very distinct, strongly developed anticlinal cellular walls (Fig. 28F-H). The cells are elongate, tetragonal, usually oblong, 30-60 $\mu \mathrm{m}$ long, and 10-20 $\mu \mathrm{m}$ wide and orientated parallel to the axial length of the strobilus. Irregular, oval to ellipsoid structures, 10-15 $\mu \mathrm{m}$ long and 5-8 $\mu \mathrm{m}$ wide, occur on the outer axial surface. They occur most commonly on the tips of very flat papillae (Fig. 28G), their function is not known.

Remarks. - The syntypes of Florinanthus volkmannii were described from Stradonice (Hýskov relict) by Ettingshausen (1852), who considered the species to belong to Calamites. He figured 14 specimens on five figures, only seven of which are cordaitalean fertile organs, the other eight are in fact sphenopsids. The Ettingshausen's (1852) seven cordaitalean fertile organs (pl. 5, figs 1-3) are assignable to Florinanthus volkmannii. Ettingshausen's (1852) pl. 5, fig. 1 (see Fig. 29) represents 5 specimens. The four fertile organs belong to Florinanthus volkmannii [Fig. 29, Ettingshausen (1852), pl. 5, fig. 1]. The different specimen in the middle belongs to some calamite cone. The specimen in Ettingshausen's pl. 6, fig. 1 also represents a calamite cone and that in fig. 2 is a Calamites pith cast.

Florinanthus volkmannii is a small cordaitalean fertile organ. This name is frequently used in the literature, but presumably represents several different species. F. volkmannii sensu stricto is characterised by a very narrow axis that is usually 1 to $1.5 \mathrm{~mm}$ wide whereas axes figured by different authors are usually wider: $2 \mathrm{~mm}$ (Zeiller 1886),
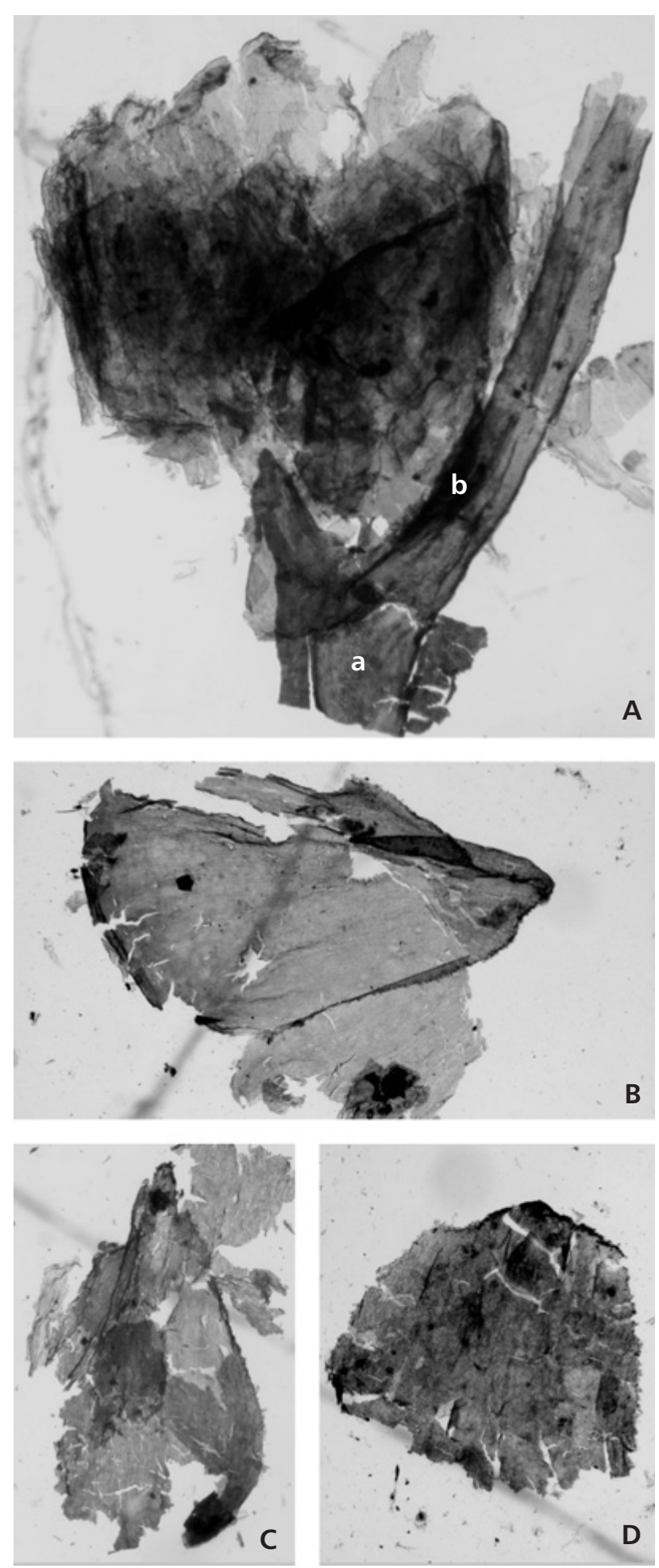

Figure 24. Florinanthus volkmannii (Ettingshausen) nov. comb. - A - a macerated "bud", a - fertile organ axis, b - bract, slide 416/12, $\times 20$. - B-D - macerated sterile scales; B - from the central part of a "bud", C - from the terminal part of a "bud", slide 416/20, D - terminal fragment of a scale from the basal part of a "bud", and B and C slide $416 / 19$, all $\times 25$. 

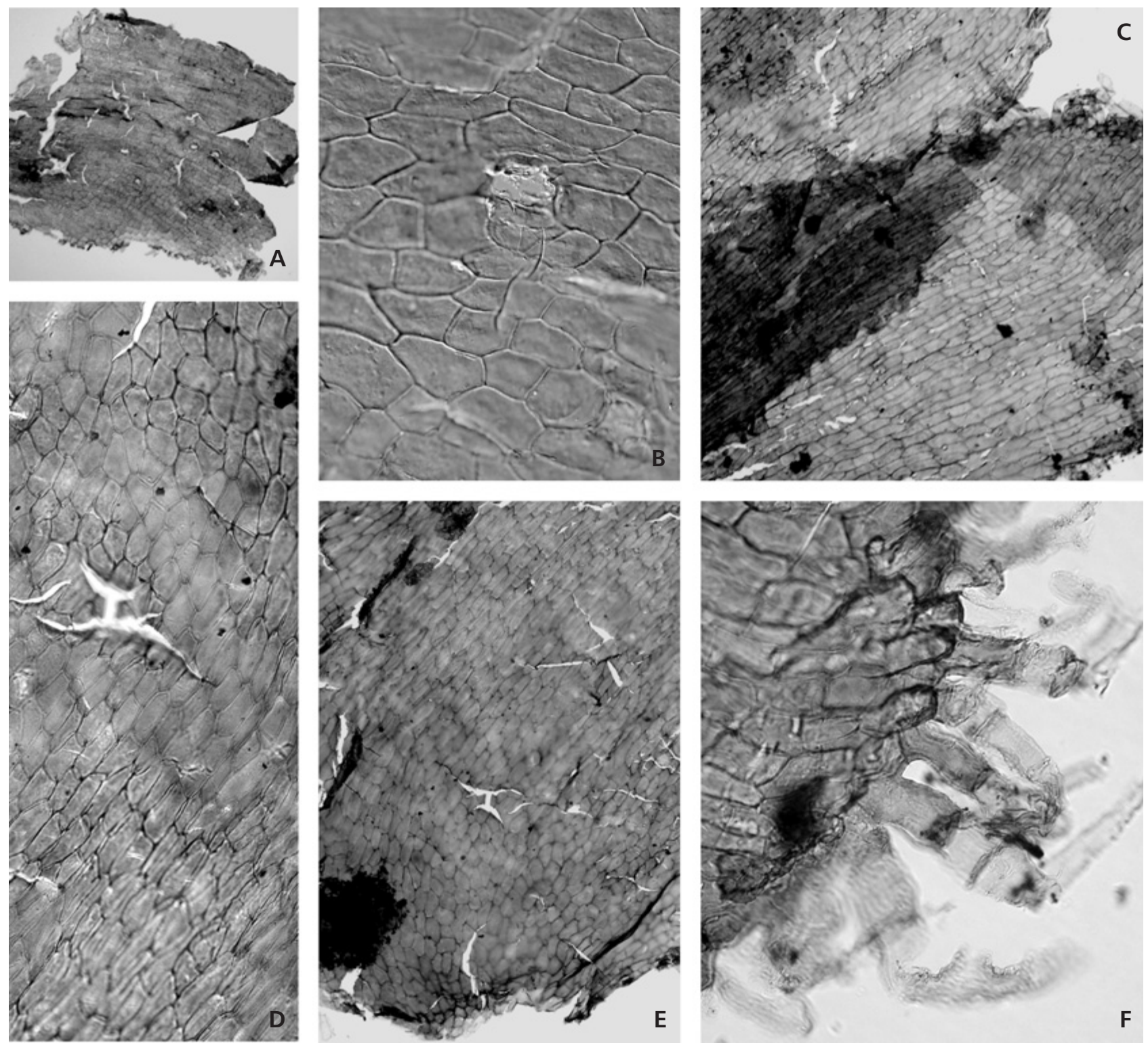

Figure 25. Cuticles of sterile scales of Florinanthus volkmannii (Ettingshausen) comb. nov. (from Fig. 25A). $\bullet$ A - a scale fragment (abaxial side) with few stomata, $\times 50$. $\bullet B-$ abaxial cuticle of a scale with two stomata (a detail from Fig. A), 416/10, $\times 400 . \bullet C$-adaxial and abaxial cuticles of a scale, slide $416 / 11, \times 100 . \bullet$ D - detail of cells from Fig. $25 \mathrm{E}, \times 200$. $\bullet$ E - adaxial cuticle of a scale in the basal part, slide $416 / 11, \times 100$. F - margin of a scale with trichomes, slide 416/11, $\times 400$.

$4 \mathrm{~mm}$ (Seward 1917), $4.5 \mathrm{~mm}$ (Crookall 1970), $2 \mathrm{~mm}$ (Havlena 1971), or narrower, < $1 \mathrm{~mm}$ (Lee 1963). Disregarding axis width, the fertile organs "Cordaitanthus volkmannii" Ettingshausen of the above mentioned authors, differs from Ettingshausen's (1852) species. The most similar to Ettingshausen's species is the specimen figured by Crookall (1970). The shape and dimension of axillary shoots are very similar, however, the bracts of Crookall's specimen are shorter and bent differently. Lee's (1963) specimen has obovate axillary shoots and very short bracts. Zeiller's (1886) specimen has oval axillary shoots without scales, very different from Ettingshausen's (1852) specimens. Preservation is a problem however, as many fertile organs are not well enough preserved for detailed comparison. Fertile organs of this Florinanthus volkmannii have been described as being female cones (Seward 1917, Lee 1963, Crookall 1970). However, this study shows that $F$. volkmannii is a male fertile organ which is proved by accumulations of prepollen clusters on sterile scales and pollen sacs on some Stradonice samples. Moreover, Halle in 1942 wrote on some labels for Ettingshausen's collection in the "Geologische Bundesanstalt" in Vienna a remark that Florinanthus volkmannii is a male fertile organ. 

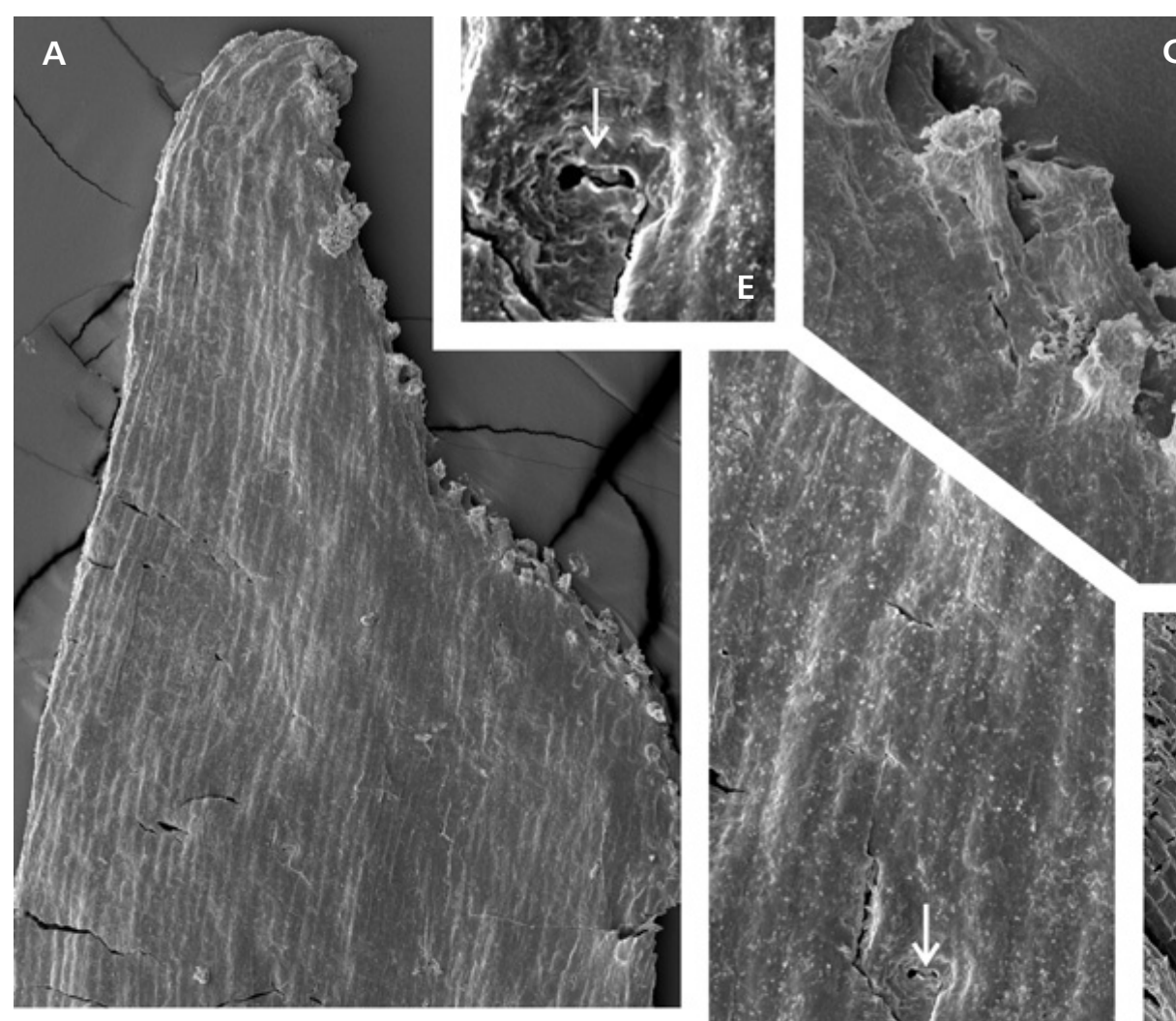

C
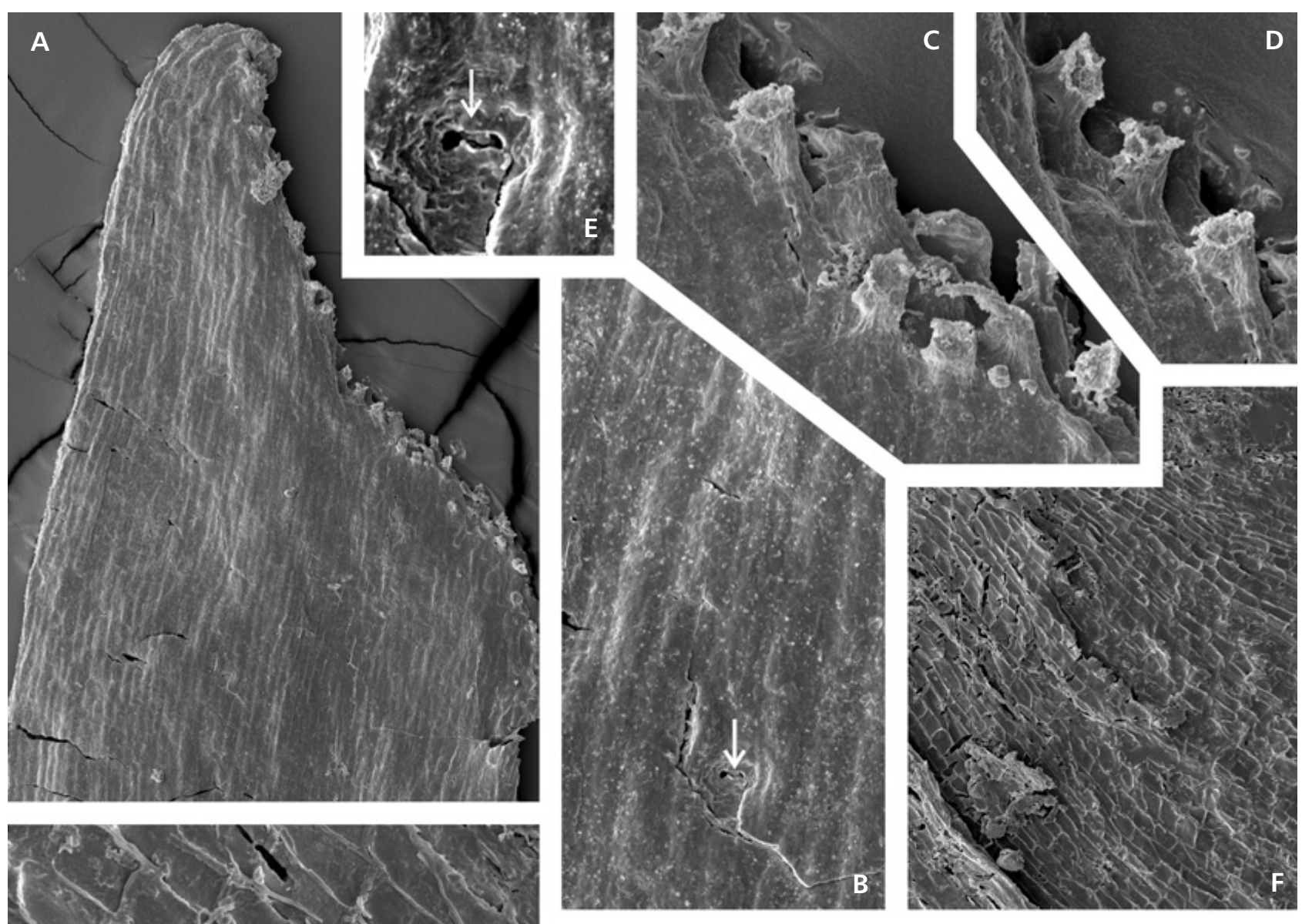

B
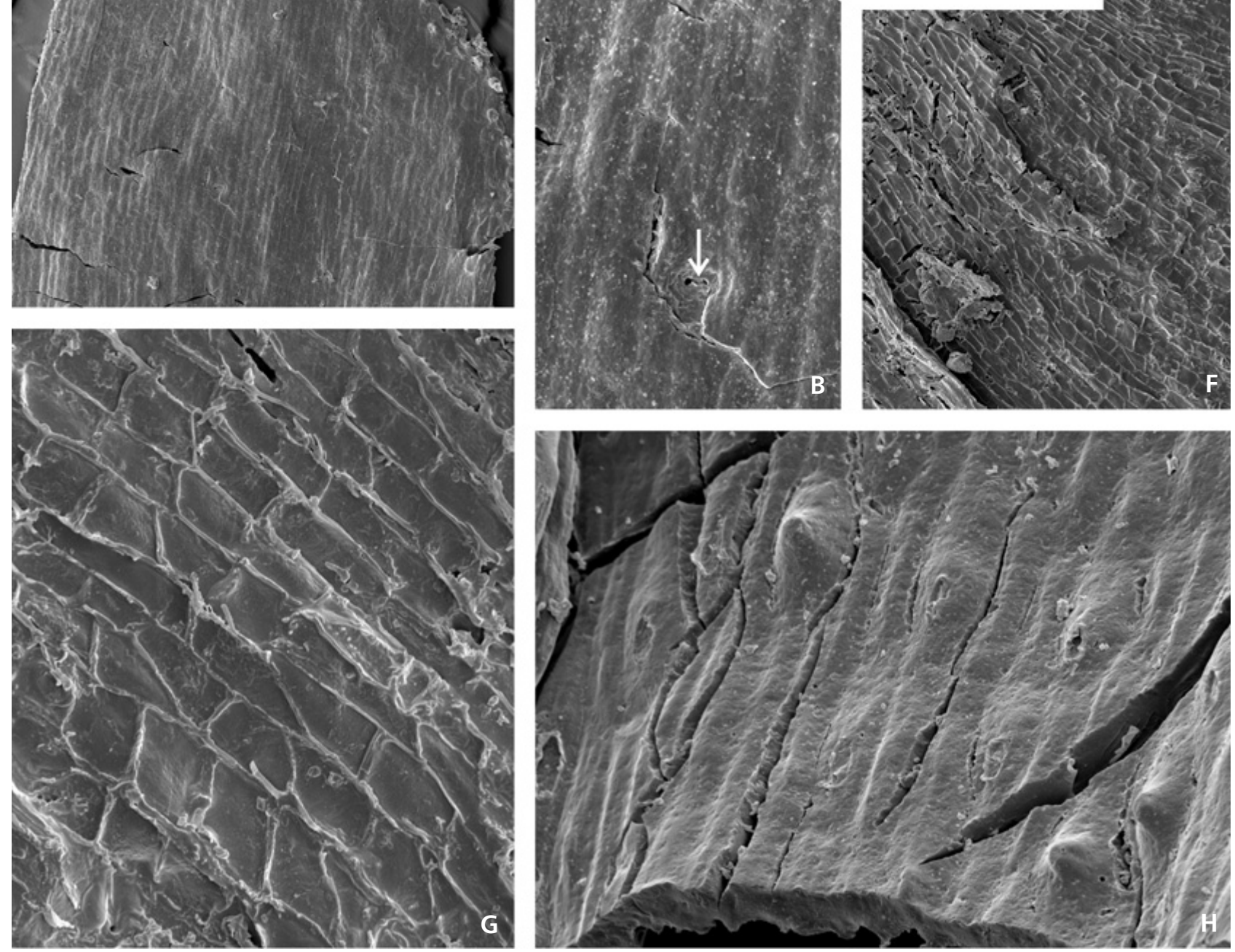

Figure 26. Cuticles of sterile scales of Florinanthus volkmannii (Ettingshausen) comb. nov. under SEM. $\bullet$ A - outer surface of a scale with small trichomes situated on the margin, stump 30, photo E5896-10, × 110. B - small slit (arrow) on the cuticle of unknown function (from Fig. 26A), $\times 110$. - C, D - margin of a scale with trichomes (from Fig. 26A), $\times 550 . \bullet$ E - scale surface showing oriented cells and a "slit" (arrow) (from Fig. $26 \mathrm{~A}, \mathrm{~B}$ ), $\times 1100$. - F - inner surface of scale with well visible anticlinal cell walls, $\times 110 . \bullet \mathrm{G}$ - detail of cells from Fig. $26 \mathrm{~F}, \times 440 \cdot \bullet \mathrm{H}$ - detail of outer view of the scale surface with papillae and elongate oval structures of unknown function, $\times 440$. 

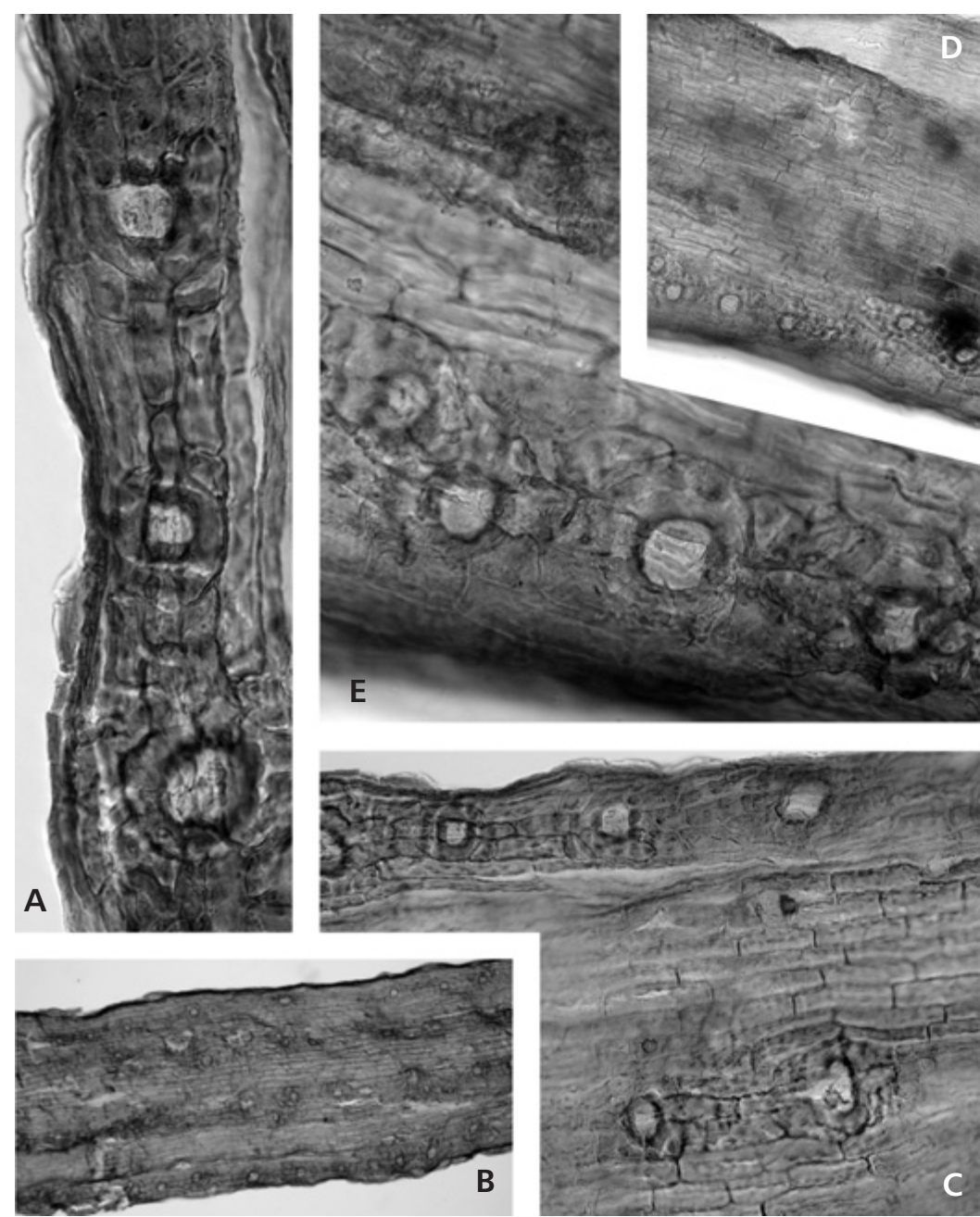
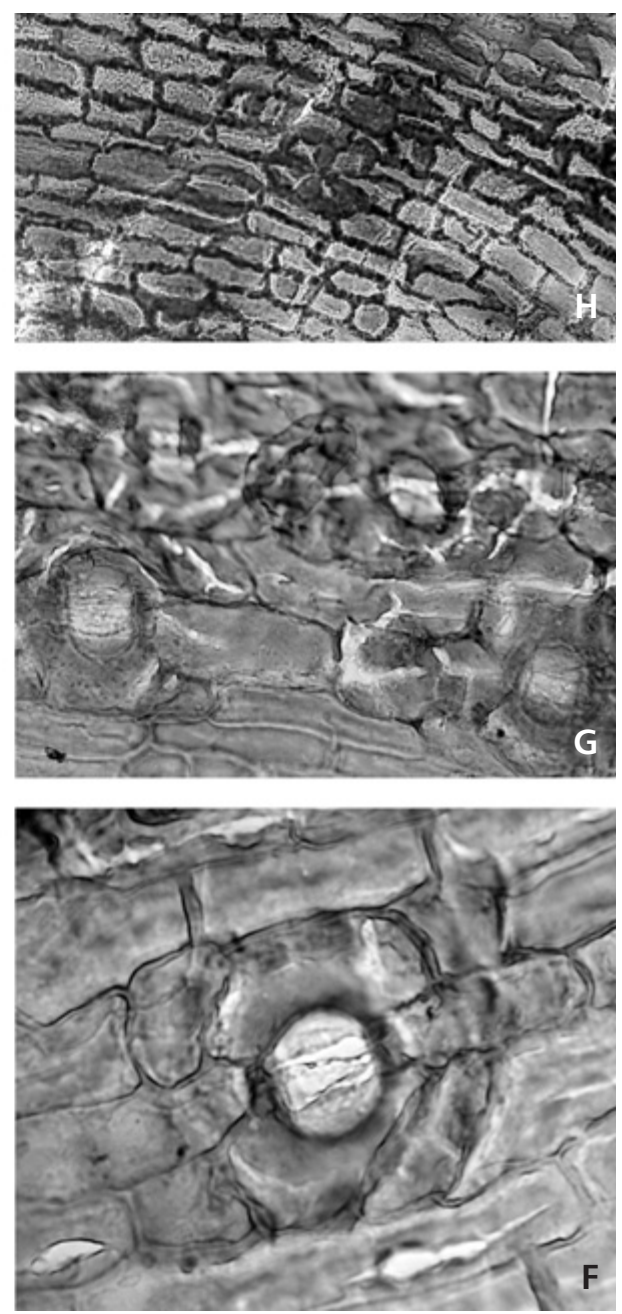

Figure 27. Cuticles of bracts $(\mathrm{A}-\mathrm{G})$ and axis $(\mathrm{H})$ of Florinanthus volkmannii (Ettingshausen) comb. nov. (from Fig 23A). $\bullet$ A - details of stomatal row with three stomata from Fig. 27B, $\times 340$. $\bullet$ B - "Abaxial" side of a bract with four stomatal rows, slide 416/1, $\times 42.5$. $\bullet$ C - details of two stomatal rows from Fig. $27 \mathrm{~B}, \times 170$. $\bullet$ D, E - probably part adaxial and part abaxial cuticle with stomatal row, slide $416 / 12, \mathrm{D} \times 85, \mathrm{E} \times 340$. $\bullet \mathrm{F}-$ detail of a stoma, slide $416 / 15, \times 680$. $\bullet \mathrm{G}$ - detail of stomata of double stomatal row, slide $416 / 14, \times 340$. $\bullet \mathrm{H}-$ cuticle of fertile organ axis with thick-walled cells, slide 416/12, × 170 .

\section{Pollen grains}

\section{“Cordaianthus" and "in situ” prepollen grains}

Pollen grains isolated from pollen sacs of the male reproductive organ "Cordaianthus" Grand'Eury, 1877 were very credibly described by Renault (1879) in his comprehensive study of reproductive cordaitalean parts from silicified material of Stephanian age collected from the Grand-Croix locality near Saint-Étienne, France. The general diagnoses for "in situ" and dispersed pollen grains was fixed by Renault (1879) and used in subsequent publications dealing with "Cordaianthus" pollen grains (Renault 1881, 1896). Florin (1936) described "in situ" pollen of C. saportanus Renault from the typical locality. Schopf et al. $(1944$, pp. 58, 59) proposed the genus Florinites to circumscribe all sporae dispersae pollen grains of known cordaitalean affinity. The genus Florinites was defined (Schopf et al. 1944) as: bilateral pollen grains, broadly elliptical in outline. Body somewhat more spherical and nearly entirely enclosed by bladder. Bladder and body walls are joined distally. Trilete imprint (where discernible) is vestigial.

However, the diagnosis of Florinites became broadly interpreted and a great number of species with a wide range of sizes, morphologies, and haptotypic features were ascribed to the genus Florinites Schopf, Wilson \& Bentall, 1944 (see Kosanke 1950, Butterworth \& Williams 1954, Balme \& Henelly 1955, Potonié \& Kremp 1956, Wilson \& Hoffmaister 1956, Bhardwaj 1957, Dybová \& Jachowicz 1957, Alpern 1959, Kalibová 1965, Felix \& Burdbridge 1967, Peppers 1970).

Millay \& Taylor (1974) studied in detail numerous well preserved Florinites-type pollen grains isolated from 

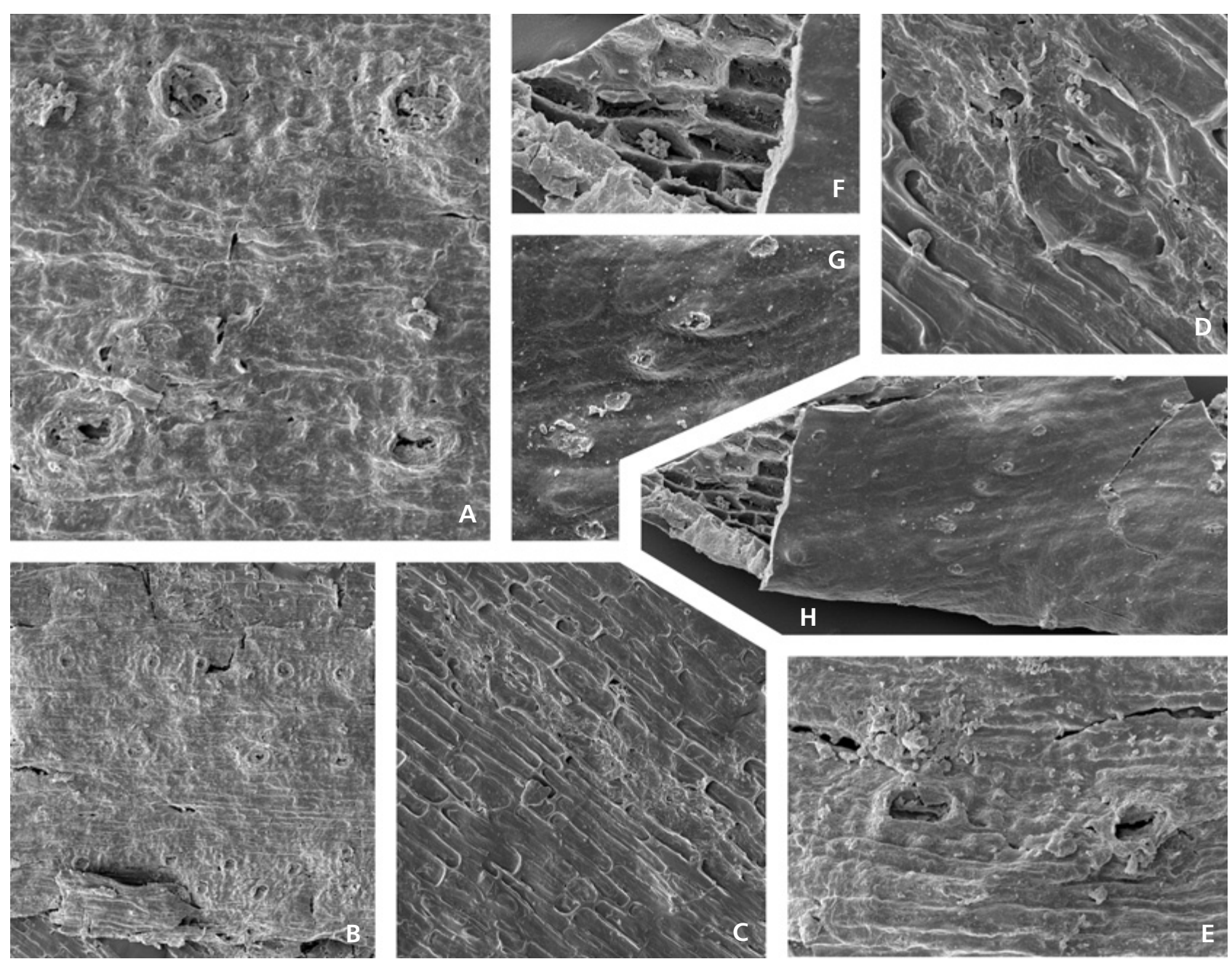

H

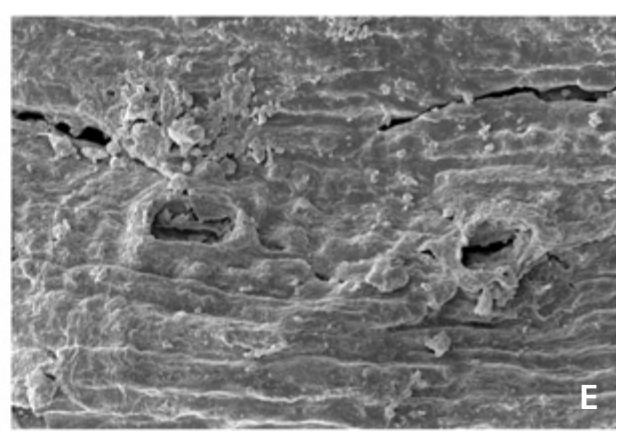

Figure 28. Cuticles of bracts of Florinanthus volkmannii (Ettingshausen) comb. nov. under SEM. $\bullet$ A - detail of 4 stomata from Fig. $28 \mathrm{~B}$ with slightly developed crypt, $\times 340 . \bullet B-$ outer view of abaxial cuticle of a bract with three stomatal rows, stump 30, photo E5896-22, $\times 85$. $\bullet$ C - inner view on abaxial cuticle with a stomatal row, photo E5896-23, $\times 170$. $\bullet$ D - a detail of a stoma from Fig. $28 \mathrm{C}, \times 510$. $\bullet$ E - a detail of two stomata with crypts, photo E5896-22det3, $\times 340$. $\bullet$ F - inner view on well-developed anticlinal cell walls - a detail from Fig. $28 \mathrm{H}, \times 340$. $\bullet \mathrm{G}-\mathrm{a}$ detail from Fig. $28 \mathrm{H}$ with oval structures of unknown function, $\times 340 . \bullet \mathrm{H}$ - cuticle of the fertile organ axis. In front, outer view of the cuticle with slightly marked cellular outlines; behind, inner view with prominent anticlinal walls; SEM stump 30, photo E5896-28, $\times 170$.

"Cordaianthus" concinnus Delevoryas, 1953 and "Cordaitanthus" schueleri (Darrah) Fry, 1956, together with other dispersed pollen from Kansas and Iowa. They defined Florinites as bilaterally symmetrical alete pollen grains consisting of a circular to oval central body surrounded by a large equatorial saccus. The saccus is attached to the corpus on both the proximal and distal surfaces (see Millay \& Taylor 1974, p. 81).

Florinites pellucidus (Wilson \& Coe) Wilson, 1958 was chosen as the type species. This implies that only alete pollen grains are accommodated in the genus Florinites, whereas other pollen grains with a monolete, triletoid or trilete scar have been expelled from the genus Florinites.

Millay \& Taylor (1974) also described pollen grains from a pollen sac dispersed among cone scales of "Cordaianthus-like" reproductive structures, and estab- lished two new monosaccate genera. The characteristic features of Sullisaccites and Felixipollenites are given in Table 3. These authors also discussed the ultrastructural organization of saccate pollen and evolution of cordaitalean pollen. Saccate pollen grains have a two-layered exine, with an outer wall layer (sexine) and an inner wall layer (nexine). Millay \& Taylor (1976) also proposed an evolutionary sequence for cordaitalean pollen grains.

\section{Description of pollen grains from Florinanthus volkmannii (Ettingshausen) comb. nov.}

Pollen grains of $F$. volkmannii are monosaccate, bilateral, 60 (75) $85 \mu \mathrm{m} \times 32(55) 62 \mu \mathrm{m}$, with an amb that is broadly elliptical from a polar view and elongate oval from an equatorial view. The central body is hexagonal, oval to 
Table 2. Overview of some in situ Florinites isolated from cordaitalean fertile organs. Abbreviation: * type species of Florinanthus Ignatiev \& Meyen, 1989, ** D3 - petrified specimens, D2 - compression/impression specimens.

\begin{tabular}{|c|c|c|c|c|c|c|}
\hline Parent plants & $* *$ & Diameter & Shape and features & Name & Age and country & References \\
\hline $\begin{array}{l}\text { Florinanthus (al. } \\
\text { Cordaitanthus) saportanus } \\
\text { (Renault, 1879) Ignatiev \& } \\
\text { Meyen, } 1989\end{array}$ & D3 & $78-93 \mu \mathrm{m}$ & $\begin{array}{l}\text { Oval, monosaccate, } \\
\text { leptomate, corpus } \\
\text { subcircular }\end{array}$ & $\begin{array}{l}\text { Florinites sp. } \\
\text { (isolated from } \\
\text { anther sacs) }\end{array}$ & $\begin{array}{l}\text { Carboniferous, } \\
\text { France }\end{array}$ & $\begin{array}{l}\text { Florin (1936), Renault (1879), } \\
\text { Scott (1923), } \\
\text { Potonié (1962), Balme (1995) }\end{array}$ \\
\hline $\begin{array}{l}\text { Cordaianthus gemmifer } \\
\text { Grand'Eury, } 1877\end{array}$ & D3 & $\begin{array}{l}\text { About } 60 \mu \mathrm{m} \\
\text { broad }\end{array}$ & $\begin{array}{l}\text { A small trilete mark } \\
\text { on the proximal face } \\
\text { of the corpus }\end{array}$ & Florinites sp. & $\begin{array}{l}\text { Carboniferous, } \\
\text { France }\end{array}$ & $\begin{array}{l}\text { Brush \& Barghoorn (1962); } \\
\text { Potonié }(1962,1967)\end{array}$ \\
\hline $\begin{array}{l}\text { Florinanthus (al. } \\
\text { Cordaianthus) concinnus } \\
\text { (Delevoryas, 1953) Ignatiev \& } \\
\text { Meyen, } 1989 *\end{array}$ & D3 & $44-71 \mu \mathrm{m}$ & $\begin{array}{l}\text { Oval, monosaccate, } \\
\text { corpus circular smooth } \\
\text { proximally and } \\
\text { granulate distally }\end{array}$ & $\begin{array}{l}\text { Florinites } \\
\text { pellucidus } \\
\text { (Wilson \& Coe) } \\
\text { Wilson }\end{array}$ & $\begin{array}{l}\text { Carboniferous, } \\
\text { USA }\end{array}$ & $\begin{array}{l}\text { Millay \& Taylor }(1974,1976) \text {; } \\
\text { Brush \& Barghoorn (1962); } \\
\text { Meyen (1984, 1987); Taylor } \\
\text { (1981, 1988); Taylor \& Taylor } \\
\text { (1993); Balme (1995) }\end{array}$ \\
\hline $\begin{array}{l}\text { Renaulticonus (al. } \\
\text { Cordaianthus) grandeuryi } \\
\text { (Brongniart) Ignatiev \& } \\
\text { Meyen, } 1989\end{array}$ & D3 & About $100 \mu \mathrm{m}$ & $\begin{array}{l}\text { Oval, monosaccate, } \\
\text { corpus subcircular }\end{array}$ & $\begin{array}{l}\text { Florinites sp. } \\
\text { (recovered from } \\
\text { the canal of the } \\
\text { pollen chamber) }\end{array}$ & $\begin{array}{l}\text { Carboniferous, } \\
\text { France }\end{array}$ & Renault (1879) \\
\hline $\begin{array}{l}\text { Florinanthus (al. } \\
\text { Cordaitanthus) schueleri } \\
\text { (Darrah) Ignatiev \& Meyen, } \\
1989\end{array}$ & D3 & $62-89 \mu \mathrm{m}$ & $\begin{array}{l}\text { Oval, monosaccate, } \\
\text { corpus circular smooth } \\
\text { proximally and } \\
\text { granulate distally }\end{array}$ & $\begin{array}{l}\text { Florinites } \text { sp. } \\
\text { (isolated from } \\
\text { anther sacs) }\end{array}$ & $\begin{array}{l}\text { Carboniferous, } \\
\text { USA }\end{array}$ & $\begin{array}{l}\text { Millay \& Taylor (1974); Darrah } \\
\text { (1952); Fry (1956); Brush \& } \\
\text { Barghoorn (1962); Potonié } \\
(1962,1967) ; \text { Balme (1995) }\end{array}$ \\
\hline $\begin{array}{l}\text { Lesqueranthus (Gothania) } \\
\text { cones attached to stems of } \\
\text { Mesoxylon priapi (Trivett \& } \\
\text { Rothwell, 1985) }\end{array}$ & D3 & $80 \mu \mathrm{m}$ & $\begin{array}{l}\text { Oval, monosacate, } \\
\text { trilete, ?flexed } \\
\text { monolete, corpus } \\
\text { circular }\end{array}$ & Sullisaccites & $\begin{array}{l}\text { Carboniferous, } \\
\text { USA }\end{array}$ & $\begin{array}{l}\text { Millay \& Taylor (1974), } \\
\text { Trivett \& Rothwell (1985), } \\
\text { Taylor \& Taylor (1993) }\end{array}$ \\
\hline $\begin{array}{l}\text { Lesqueranthus (al. Gothania) } \\
\text { lesliana (Daghlian \& Taylor, } \\
\text { 1979) Ignatiev \& Meyen, } 1989\end{array}$ & D3 & $180 \mu \mathrm{m}$ & $\begin{array}{l}\text { Oval to subcircular, } \\
\text { monosacate, trilete, } \\
\text { distally leptomate }\end{array}$ & Felixipollenites & $\begin{array}{l}\text { Carboniferous, } \\
\text { USA }\end{array}$ & $\begin{array}{l}\text { Millay \& Taylor (1974), } \\
\text { Taylor \& Taylor (1993) }\end{array}$ \\
\hline $\begin{array}{l}\text { Florinanthus volkmannii } \\
\text { (Ettingshausen) comb. nov. }\end{array}$ & D2 & $58-85 \mu \mathrm{m}$ & $\begin{array}{l}\text { Oval, monosaccate, } \\
\text { corpus oval smooth } \\
\text { proximally and } \\
\text { granulate distally }\end{array}$ & $\begin{array}{l}\text { Florinites cf. } \\
\text { ovalis } \\
\text { Florinites cf. } \\
\text { guttatus }\end{array}$ & $\begin{array}{l}\text { Carboniferous, } \\
\text { Czech Republic }\end{array}$ & Herein \\
\hline
\end{tabular}

nearly circular from the polar view 30-51 $\mu \mathrm{m}$ long and $25-38 \mu \mathrm{m}$ broad, and is a distinct darker brown colour. The longer axes of the spore and those one of the central body are mutually perpendicular. The proximal body surface is without folds, it has $8-15 \mu \mathrm{m}$ long monolete scars (Fig. 30D, H) which curve in the centre, sometimes with an indication of an additional long third ray that suggests a transition to a trilete scar. This feature is often indistinct in light microscopy. The body outline is trapezoidal in equatorial view and tapers towards the distal side of the pollen grain (Fig. 31D). The wall of the body on the distal side has folds or pleats running along its long axis. The central body is surrounded by a large equatorial saccus, which is attached to the central body on both the proximal and distal surfaces (Fig. 30C, E, I).

The equatorial saccus covers the proximal side of the central body. The saccus is attached at a narrow zone near the proximal surface of the central body (Fig. 30I). Only part of the central body, with an oval or sickle shape, remains uncovered on the distal side. The slit is usually indiscernible.

Most studied pollen grains have the saccus torn from the proximal side and the surface of the central body is well exposed. The central body is wrinkled. The saccus is laevigate from the outer side and reticulate from the inner side (Fig. 30J).

Comparison of prepollen grains. - Three species of the genus Florinites were originally described, which are in certain aspects similar to the pollen grains isolated from Florinanthus volkmannii. They are Florinites ovalis Bhardwaj, 1957, Florinites guttatus Felix \& Burdbridge, 1967 and Florinites diversiformis Kosanke, 1950. These bilateral monosaccate species possess a central body with a darker colour, in which the longer axis is mostly perpendicular to the longer axis of the saccus. However, after the Taylor \& Millay's (1974) revision of the heterogenous genus Florinites, only monosaccate alete species (inclusive of Florinites ovalis) were kept in the genus Florinites, and the remainder of species (inclusive of Florinites guttatus and Florinites diversiformis) were excluded from this genus.

The pollen grains of Florinanthus volkmannii from Pokrok Mine, Ovčín - Přívětice Radnice Basin are very similar in morphology to two other species of pollen, Florinites ovalis and Florinites guttatus. However Florinanthus volkmannii pollen, which has a diameter 
Table 3. Comparison of some pollen taxa with "in situ" pollen isolated from Florinanthus volkmannii.

\begin{tabular}{|c|c|c|c|c|}
\hline Taxon & Symmetry an diameter & Haptotypic features & $\begin{array}{l}\text { Attachement of } \\
\text { equatorial saccus }\end{array}$ & Notice \\
\hline Florinites & $\begin{array}{l}\text { Monosaccate, radially- } \\
\text { bilaterally symmetrical }\end{array}$ & $\begin{array}{l}\text { Alete, with a distal } \\
\text { aperture }\end{array}$ & $\begin{array}{l}\text { On both proximal } \\
\text { and distal surface }\end{array}$ & $\begin{array}{l}\text { Proximal saccus corpus overlap slight to } \\
\text { absent. Saccus levigate, intrareticulate. }\end{array}$ \\
\hline Sulisaccites & $\begin{array}{l}\text { Monosaccate, bilaterally } \\
\text { symmetrical 55-80 } \mu \mathrm{m}\end{array}$ & Trilete & $\begin{array}{l}\text { On both proximal } \\
\text { and distal surface }\end{array}$ & $\begin{array}{l}\text { Proximal saccus corpus overlap slight. } \\
\text { Distal overlap approximately } 1 / 2 \text {. }\end{array}$ \\
\hline Felixipollenites & $\begin{array}{l}\text { Monosaccate, radially- } \\
\text { bilaterally symmetrical } \\
115(150) 180 \mu \mathrm{m}\end{array}$ & $\begin{array}{l}\text { Trilete, triletoid } \\
\text { more seldom } \\
\text { monolete }\end{array}$ & $\begin{array}{l}\text { On both proximal } \\
\text { and distal surface }\end{array}$ & $\begin{array}{l}\text { Proximal saccus corpus overlap slight to } \\
\text { absent. }\end{array}$ \\
\hline Florinites guttatus & $\begin{array}{l}\text { Monosaccate, bilaterally } \\
\text { symmetrical } \\
95-140 \mu \mathrm{m} \times 120-70 \mu \mathrm{m}\end{array}$ & Monolete-triletoid & $\begin{array}{l}\text { On both proximal } \\
\text { and distal surface }\end{array}$ & $\begin{array}{l}\text { The spore body covered by thin granulose } \\
\text { membrane proximally and coarser } \\
\text { reticuloid membrane distally. }\end{array}$ \\
\hline $\begin{array}{l}\text { Pseudoillinites } \\
\text { Basionym = Florinites } \\
\text { diversiformis }\end{array}$ & $\begin{array}{l}\text { Monosaccate, bilaterally } \\
\text { symmetrical }\end{array}$ & Monolete & $\begin{array}{l}\text { Proximal surface of } \\
\text { central body free } \\
\text { from saccus }\end{array}$ & $\begin{array}{l}\text { Appearance of a bisaccate grain. Saccus } \\
\text { coarsely intrareticulate proximal surface of } \\
\text { central body free from saccus. }\end{array}$ \\
\hline $\begin{array}{l}\text { Pollen isolated from } \\
\text { Florinanthus volkmannii }\end{array}$ & $\begin{array}{l}\text { Monosaccate, bilaterally } \\
\text { symetrical } 60(75) 85 \mu \mathrm{m} \times \\
32(55) 62 \mu \mathrm{m}\end{array}$ & Monolete-triletoid & $\begin{array}{l}\text { On both proximal } \\
\text { and distal surface }\end{array}$ & $\begin{array}{l}\text { The spore body covered by thin smooth to } \\
\text { granulose membrane proximally and } \\
\text { coarser granulate membrane distally. }\end{array}$ \\
\hline
\end{tabular}

58-85 $\mu \mathrm{m}$, is intermediate in size between Florinites ovalis $(42-65 \mu \mathrm{m})$ and Florinites guttatus $(95-135 \mu \mathrm{m})$ with a monolete-triletoid scar.

The central body of some Bohemian specimens from the Radnice Basin extends nearly the full width of the saccus, resulting in the appearance of a bisaccate grain. Such pollen grains could be morphologically similar to Pseudoillinites Ravn (1979), a genus erected to accommodate bilateral, monosaccate, monolete prepollen or pollen grains. Pseudoillinites (al. Florinites) diversiformis (Kosanke, 1950) Ravn, 1979 was chosen as its type species.

Pollen grains isolated from Florinanthus volkmannii differ from pollen grains of the morphogenera Florinites and Sulisaccites (Schopf, Wilson \& Bental) Millay \& Taylor, 1974 by the presence of a monolete - triletoid scar on the proximal side of the central body and by having a thicker exine.

These pollen grains are partly comparable with the genus Felixipollenites in the shape of the haptotypic feature (monolete-triletoid) and in the stronger nature of the central body exine. However, Felixipollenites pollen grains are radially - bilaterally symmetrical and the proximal surface of the grains (Millay \& Taylor 1974, pl. 42, figs 5, 6) show a reticulate ornamentation that is clearly limited to the proximal saccus corpus attachment region. Millay \& Taylor (1976, p. 68) consider this feature to be primitive.

Potonieisporites is a monosaccate, monolete spore, but pollen grains isolated from Florinanthus volkmannii show a gradation from monolete to trilete. It seems that the Florinanthus volkmannii pollen grains studied are not comparable with any of above-mentioned taxa (Table 3), and they belong, perhaps, to a new genus. However, the studied pollen grains are preserved as compression/impressions and they are not as well-preserved as pollen grains from coal balls described by Millay \& Taylor (1974).

\section{Pith casts}

\section{Artisia Sternberg, 1838}

Type species. - Artisia transversa (Artis) Corda in Sternberg, 1838

\section{Artisia approximata Brongniart ex Lindley \& Hutton, 1837}

Figures 32A-D

1821 Calamites fasciatus Sternberg, p. 27, pl. 17, fig. 3.

1825 Calamites fasciatus Sternberg, tent. 24.

1828 Sternbergia approximata Brongniart, p. 137 (nomen nudum).

1837 Sternbergia approximata Brongniart ex Lindley \& Hutton, p. 187, pls 224, 225.

1838 Artisia approximata (Brongniart ex Lindley \& Hutton). - Corda in Sternberg, p. XXII (Skizzen).

1838 Tithymalites biformis Presl in Sternberg, p. 205, pl. 53, figs $1-6$.

Description. - Casts more or less cylindrical, 15-30 $\mathrm{mm}$ in diameter and 50-200 mm-long fragments, bearing alternate approximately horizontal septa and spaces between the septa (Specimen numbers are given in the "Material" section). The spaces are usually rounded, 0.6 to $2.0 \mathrm{~mm}$ in height, rarely anastomosing. Connection between Artisia and a trunk or twig surface is illustrated in Fig. $20 \mathrm{H}$.

Remarks. - Only two species of Artisia, Artisia tranversa and Artisia approximata, are generally accepted (Van Amerom 1998, Fossilium catalogues, pp. 6-9). The other "species" are considered synonyms of these two. The Artisia approximata-type does not have the longitudinal ridges 


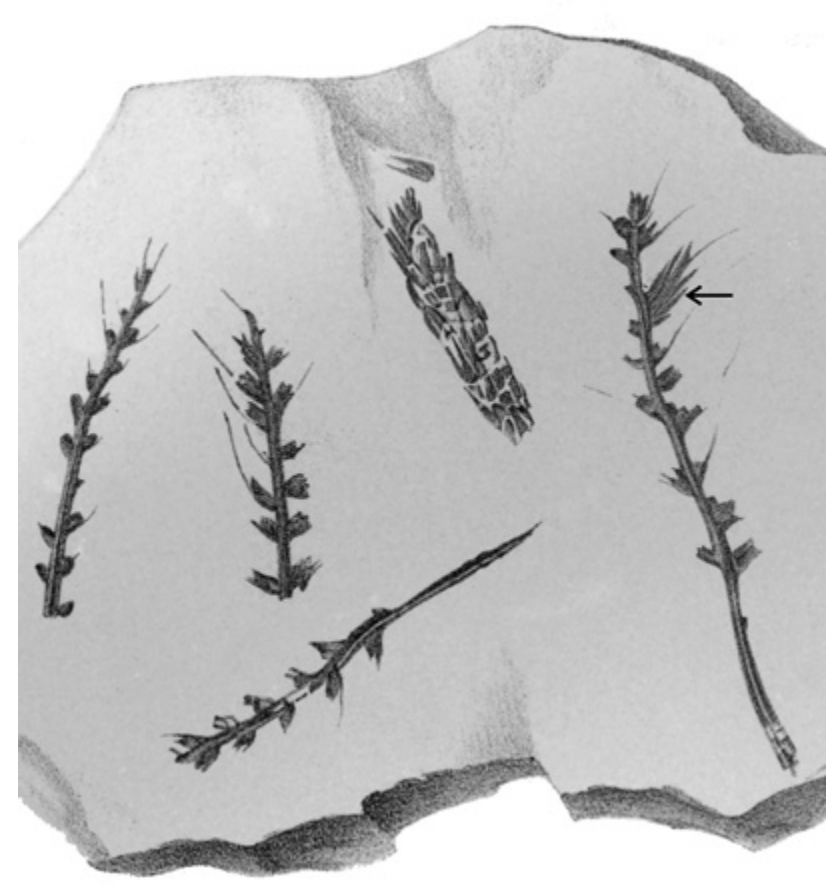

Figure 29. Copy of the Ettingshausen's (1852) pl. 5, fig. 1. Only four specimens belong to Florinanthus volkmannii (Ettingshausen) comb. nov. Loc. Stradonice (Hýskov relict), Bolsovian. The arrow represents a Rhacopteris pinnule. $\times 1$.

of Artisia transversa. Only Artisia approximata has been found at the Ovčín locality and therefore it could belong to Cordaites borassifolius. The A. approximata stem type was possibly produced by more than one species of cordaitalean plants as only two species of Artisia have been described, whereas many more species of the Cordaites leaf morphology are known. For example, the pith cast of the newly described species Cordaites schatzlarensis Šmůnek \& Libertín, 2006 is of the A. approximata type.

\section{Palaeoecology}

The interpretation of the palaeoecological characteristics of Cordaites borassifolius is based on the occurrence of its remains in the bělka bed in the roof of the Lower Radnice Coal. Plant remains preserved there represent a peatforming plant assemblage buried in situ by volcanic ash fall
(Opluštil et al. 2005). Therefore, Cordaites borassifolius is interpreted as a peat-forming representative of this genus, preferring a peat substrate. The Lower Radnice Coal is generally rich in volcanic ash and thin sedimentary partings (Andrusov et al. 1940). In excavations, the top of the seam is characterised by alternations of carbonaceous shale ranging to impure coal with occasional vitrain bands. This indicates the existence of an inundated planar eutrophic mire.

Excavations in the Radnice Basin provided information on the synecology of this species. Here, Cordaites borassifolius formed part of a diversified forest ecosystem with a well-developed shrubby storey and ground cover (Opluštil et al. 2007, 2009). More than 25 species have been identified in the vicinity of representatives of this species. These include sphenophytes (Calamites and Sphenophyllum), ferns (e.g., Corynepteris angustissima, Desmopteris longifolia, Senftenbergia plumosa, Hymenotheca sp.), pteridosperms (e.g., Sphenopteris mixta, Palmatopteris furcata and Eusphenopteris nummularia) and lycophytes among which the most common are Lepidodendron lycopodioides, Lepidodendron simile sensu Němejc (1947), which is a Flemingites-bearing species, Lepidophloios cf. acerosus and Spencerites havlenae. Cordaites borassifolius was probably among the tallest species of the ecosystem and together with lepidodendrids also the greatest contributor to bio mass.

Cordaitaleans were a diverse group and cumulatively encompassed a broad ecological amplitude ranging from dry substrates (Falcon-Lang \& Scott 2000, Falcon-Lang 2003, Falcon-Lang \& Bashforth 2004) to brackish environments (Falcon-Lang 2005) and waterlogged peats (DiMichele \& Phillips 1994). Perhaps tolerance to physiological drought enabled cordaitaleans to live in mires. The cordaitaleans, for the most part, were a major, as well as probably the tallest component of the Bolsovian upland vegetation in southwest Newfoundland, Canada (Falcon-Lang \& Bashforth 2004) where they reached nearly $50 \mathrm{~m}$ in height. On the other hand, the smallest forms, Pennsylvanioxylon nauertianum (= Cordaixylon dumusum Rothwell \& Warner, 1984), were shrubs that grew in peat mires. The mangrove-like trees, Pennsylvanioxylon birame (Cridland 1964, Costanza 1985) that lived in brackish coastal habitats were probably no more than $5 \mathrm{~m}$ tall. Present in Upper Bolsovian coal balls from Iowa (USA), Falcon-Lang (2005) described the occurrence of similar

Figure 30. Pollen grains isolated from Florinanthus volkmannii (Ettingshausen) comb. nov., Ovčín locality, under SEM. • A - clump of pollen grains (part of the sporangium) $\times 340 . \bullet \mathrm{B}-$ proximal view. Strongly corroded pollen grain. Central body with triletoid suture, $\times 1180$. $\bullet \mathrm{C}-$ proximal-lateral view. Relatively well-preserved pollen grain. It seems that the saccus overlaps all the proximal part of the central body. Saccus unevenly levigate, saccus corpus attachment levigate to finely granulate, $\times 1180$. $\bullet$ D - proximal view. Strongly corroded pollen grain. Central body with monolete suture. Notice the distinct medial deflection of the suture, $\times 1180$. $\bullet$ E - distal view. Relatively well-preserved pollen grain. Saccus unevenly levigate, saccus-corpus attachment granulate, $\times 1180 . \bullet \mathrm{F}-$ distal view. Detail of the attachement of saccus from Fig. $30 \mathrm{C}, \times 2320 . \bullet \mathrm{G}-$ distal view, $\times 1180 . \bullet \mathrm{H}-$ detail of the central body with open triletoid suture. Notice rugulate ornamentation of the body, $\times 2320$. $\bullet \mathrm{I}-$ detail of the saccus from Fig. $30 \mathrm{C}$ with central body attachment, $\times 2320$. $\bullet \mathrm{J}-$ pollen grain covered by some cuticle. Only part of broken equatorial saccus is exposed. Notice internal reticulation of the saccus, $\times 2320$. 

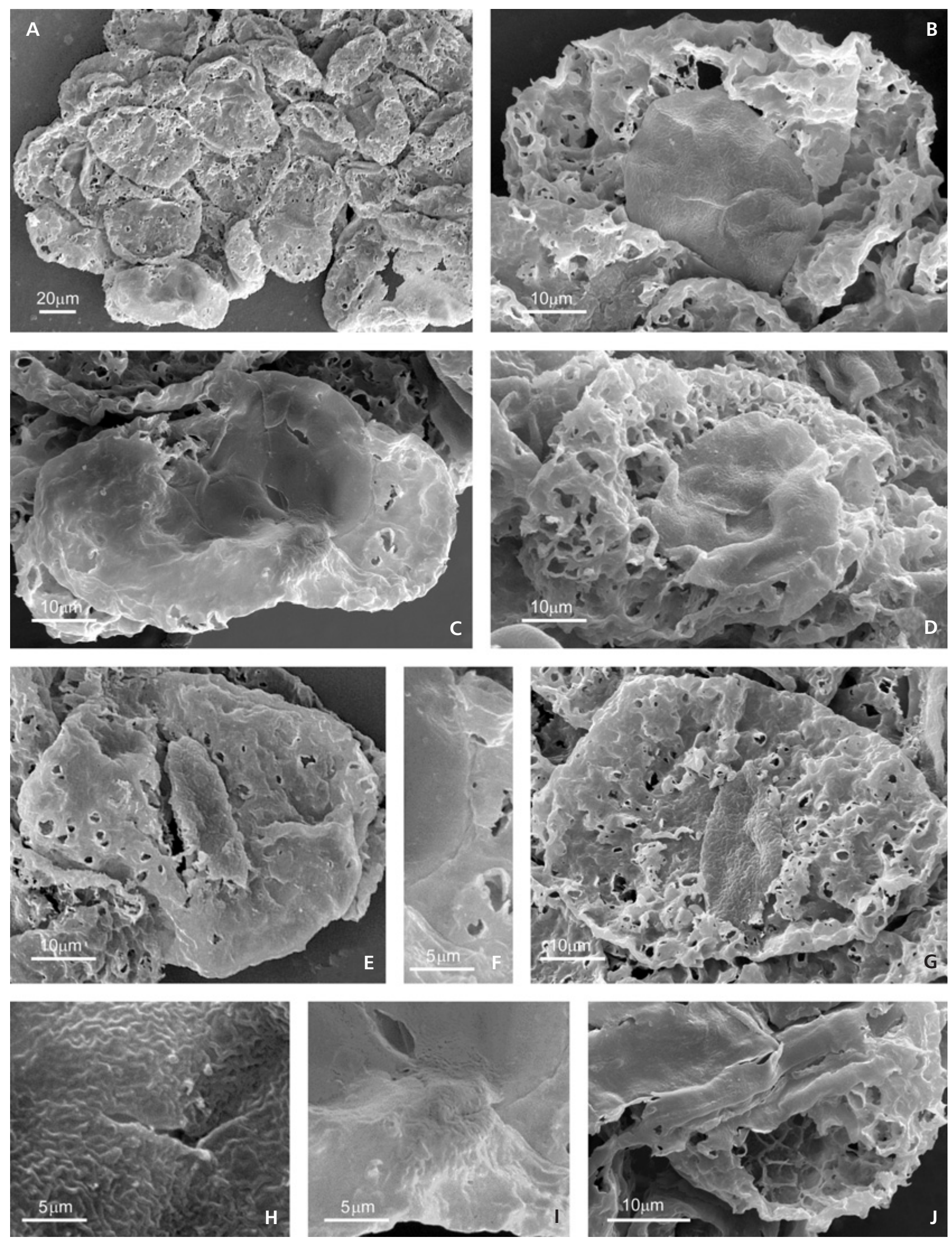

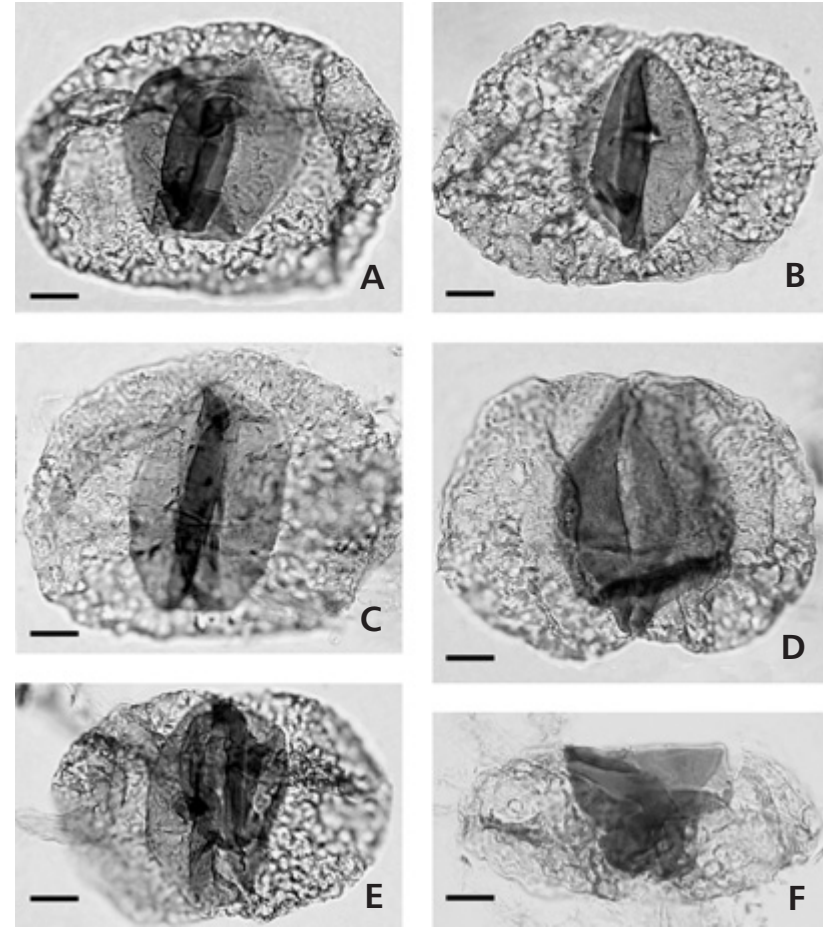

Figure 31. Pollen grains isolated from Florinanthus volkmannii, Ovčín locality. A A, C - Florinites cf. ovalis Bharadwaj, 1957, monolete suture is not seen, polar view, slide $416 / 17, \times 500$. $\bullet$ B - Florinites cf. guttatus Felix $\&$ Burdbridge 1967, pollen grains with monolete suture, polar view, B - slide 416/5, × 500. • D, E - cf. Pseudoillinites Ravn, 1979, pollen grains of a bisaccate appearance, polar view, D - slide 416/19, E - slide $416 / 11, \times 500$. $・ \mathrm{~F}-$ pollen grain of Florinanthus volkmannii in lateral view, slide $416 / 17, \times 500$.

cordaitalean trees from the Joggins Formation (Langsettian) of Nova Scotia, Canada. The trees from Joggings were of the same height as trees from Iowa and had a mangrove-like rooting system. Evidence of marine influence is unquestionably present in the Joggins Formation. The afore mentioned cordaitaleans are the extreme cases regarding overall height and are from unusual habitats. Cordaitalians that grew on clastic substrates probably grew to between 30 and $40 \mathrm{~m}$ (Grand'Eury 1877).

Two stem-genera, based on anatomical features, have been recognized in mire habitats: Mesoxylon and Pennsylvanioxylon (DiMichele \& Phillips, 1994). The stem anatomy of Cordaites borassifolius from the Radnice Basin is not known therefore direct comparison with Mesoxylon and Pennsylvanioxylon is not possible. DiMichele \& Phillips (1994) mentioned that cordaitaleans were most common in marginal areas of coal bodies that were subject to clastic influx from adjacent channels or in association with mineral partings and adjacent high-ash coals. The typical floral assemblage that includes cordaitaleans also includes calamites, some tree ferns and arborescent lycopsids. Cordaitaleans grew in planar swamps that had seasonally high water tables. The cordaitaleans in Ovčín were known to occur in the southeastern portion of the Pokrok (Ovčín Přívětice) quarry, adjacent to our excavations, where they were also recovered.

Life in mire environments probably subjected the cordaitaleans to conditions that resulted in tolerance to physiological draught. This tolerance is suggested by the xerophyllous features observed in the cuticles such as stronger cutinisation and sunken stomata with special mechanism for transpiration reduction. Such features usually occur in two different environments: In primarily dry habitat with shortage of water on well-drained clastic substrates, and in wet peat-forming environments with a shortage of nitrogen. In such settings, plants attempt to diminish transpiration by various xerophyllous adaptations. Cordaites borassifolius had such adaptations. Its adaxial cuticle was significantly thicker and had a very low density of sunken stomata. Stomata on abaxial surface are also deeply sunken with a special crypt transverse to the guard cells, further reducing transpiration.

\section{Stratigraphic range and geographic distribution}

Cordaites borassifolius leaf cuticles have been found at only several localities in the Radnice Basin and in Stradonice (= Hýskov relict) near Beroun locality and this species has been found only at the level of the Whetstone Horizon, early Bolsovian (middle Moscovian). Outside central and western Bohemia, the remains of Cordaites borassifolius have frequently been reported based on leaf morphology only. However, no reliable identification using cuticles has confirmed these identifications. Therefore, mapping the geographic distribution and stratigraphic range of the species requires further investigation.

\section{Discussion: The whole plant concept}

The first cordaitalean reconstructions were made by Grand'Eury (1877). He figured several arborescent forms, 20 to $40 \mathrm{~m}$ high, that represent canopy trees from floodplain environments. These reconstructions were adopted by many palaeobotanical textbooks in the $20^{\text {th }}$ century. It seems that Grand'Eury (1877) did not reconstruct a particular species, but rather combined features from species representing subgenera of Cordaites. Modern reconstruction, based on coal ball material, were published by Rothwell \& Warner (1984) and Costanza (1985). Rothwell \& Warner (1984) reconstructed Pennsylvanioxylon nauertianum (Andrews) Costanza (= Cordaixylon dumusum Rothwell \& Warner). They found an endarch cordaitalean stem organically conected with Cordaites leaves and pollen cones of Cordaitanthus morphology. They classified 
all these organs under a single name Cordaixylon dumusum Rothwell \& Warner, 1984. Moreover, they found disarticulated ovules and ovulate cones. These they classified as seperate morphogenera, Cardiocarpus and Cordaitanthus, although their organic connection was not demonstrated, their affinity to Cordaixylon dumusum, however, is highly probable. This plant had a bush-like habit.

The reconstruction of another cordaitalean tree, based on material from coal balls was proposed by Costansa (1985). She found, in organic connection, the following plant organs: Pennsylvanioxylon birame (stems), Amyelon iowense (roots), Cordaites principalis (leaves), Florinanthus (Cordaitanthus) concinuus (pollen-bearing shoots), Cordaitanthus sp. (ovule shoots) and Cardiocarpus spinatus (ovules). The growth habit of this $5 \mathrm{~m}$ tall plant was mangrove-like. However, it must be noted that the name Cordaites principalis in fact comprises many natural species.

The individual species of cordaitaleans cannot be determined solely by venation. Only by obtaining cuticular material from a specimen is it possible to assign it to a species taxon (Šimůnek 2007). That means that cordaitalean leaves with the venation pattern of Cordaites principalis may in fact be a leaf from any number of cuticle based taxa that have different stem and fertile organ morphologies.

The reconstruction of adpression cordaitalean plants is different from those based on coal ball derived material. Rothwell \& Warner (1984) and Costanza (1985) used the name applied to the stem to represent their completely reconstructed plant. It is not possible with the adpression preservation because anatomical features of two-dimensional stems are not preserved. Typically only the coalified surface of the trunk or the pith cast of Artisia is preserved in compression-adpression settings. It is thus impossible to determine whether the plant is Mesoxylon or Pensylvanioxylon. Therefore, we chose the leaf characteristics (including the cuticles) as the basic feature for naming the whole plant: Cordaites borassifolius. Leaves of Cordaites borassifolius were the first cordaitalean remains described by Sternberg (1821). Our excavations in the Radnice Basin yielded another cordaitalen organ genera that may or may not be assignable to Cordaites borassifolius.

The plants preserved in the bělka bed from the Radnice Basin were buried in situ by volcanic ash as indicated by common upright stems ranging from a few centimetres to nearly $1 \mathrm{~m}$ in diameter (Opluštil et al. 2009). These stems are associated with pre-eruption plant litter as well as branches broken due to volcanic ash load, found scattered in the tuff at the base of the upright parent trunk. Such associations of various plant organs with their parent stems provide a very good basis for whole plant reconstruction of several species, including Cordaites borassifolius. Specimens collected at the Ovčín localities come from a small area of about $200 \mathrm{~m}$ by $200 \mathrm{~m}$ and most probably represent the same plant
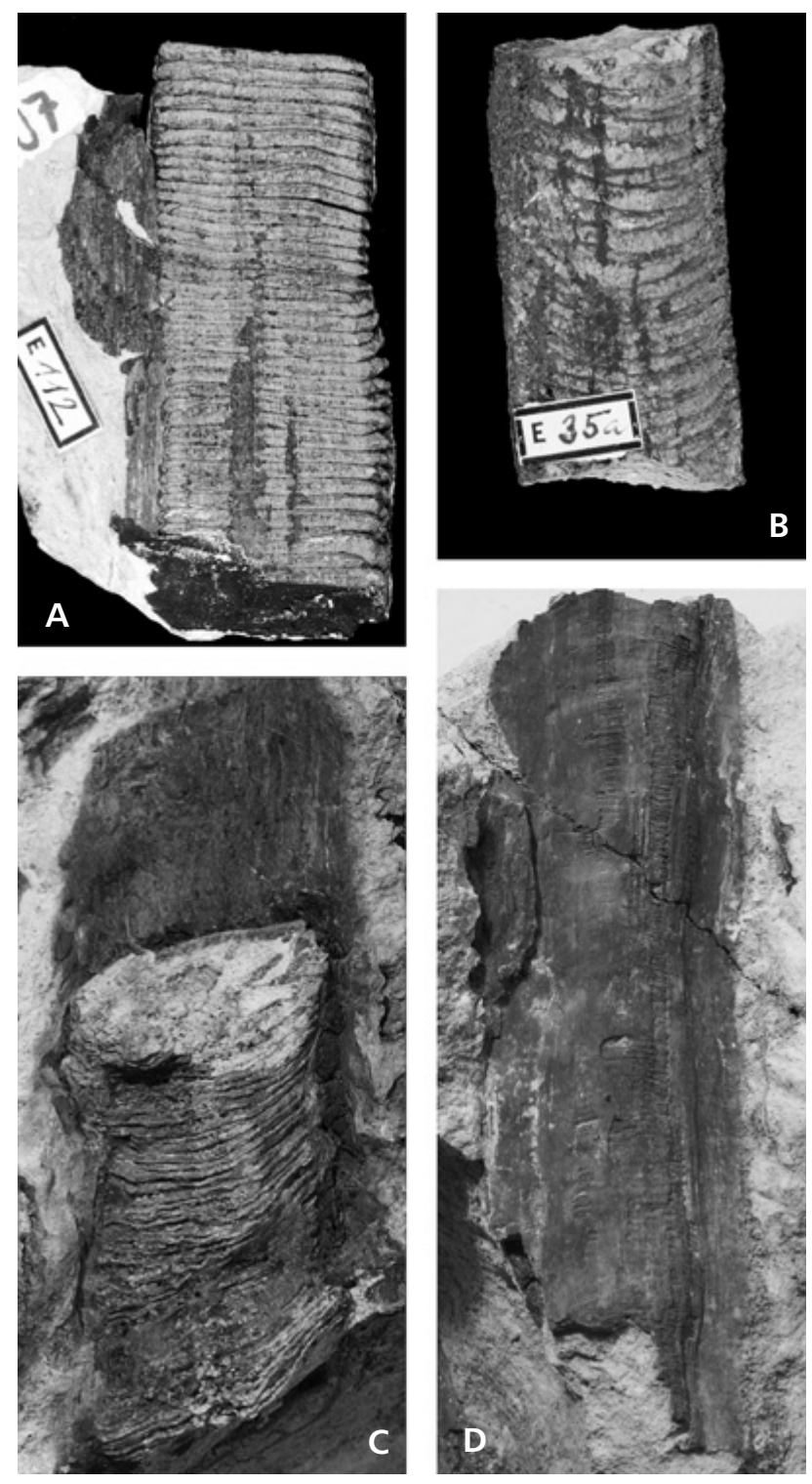

Figure 32. Artisia approximata Brongniart ex Lindley \& Hutton. - A - pith cast of "Tithynalites biformis Presl in Sternberg", locality Radnice, Inv. No. E 112 (National Museum Prague), $\times 1$. B - pith cast of "Calamites fascaitus Sternberg", loc. Radnice, Inv. No. E 35a (National Museum Prague), $\times 1 . \bullet \mathrm{C}-$ the pith cast and partly wood imprint, loc. Ovčín near Radnice, West Bohemian Museum in Plzeň, $\times 2$. $・ D-$ an imprint of Cordaites wood, loc. Ovčín near Radnice, West Bohemian Museum in Plzeň, $\times 1$.

assemblage in which only one cordaitalean species occurred. This is further supported by cuticle analysis of 11 cordaitalean leaves preserved in both the bělka and the tuffite above it. This analysis demonstrated that all these leaves belong to one species, although maybe in different ontogenetic stages as indicated by different crypt development. Furthermore, cuticles of these leaves are identical with those prepared from the holotype of Cordaites borassifolius from Svinná, about $6 \mathrm{~km}$ north of our excavations 


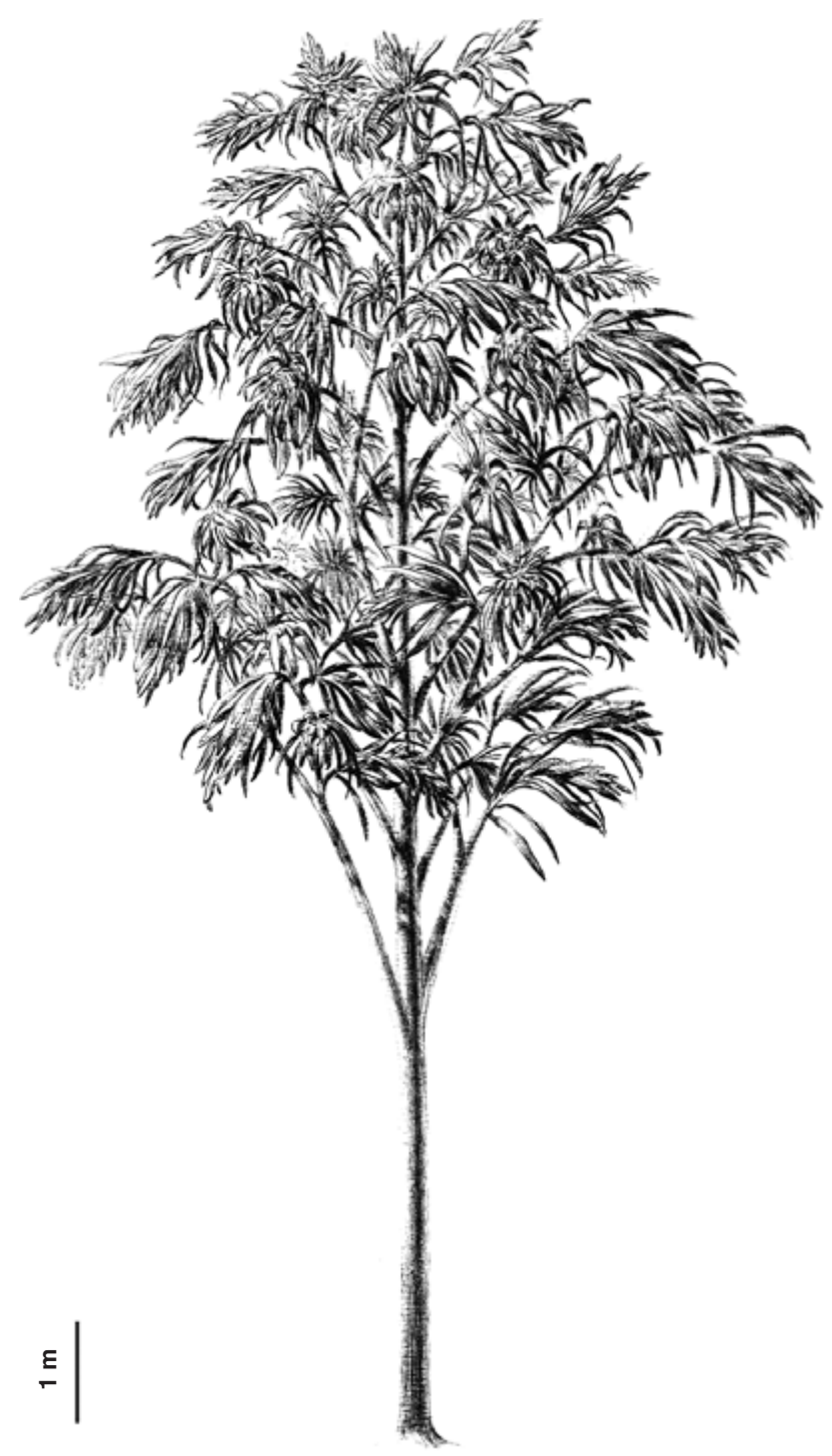

Figure 33. Whole-plant reconstruction of Cordaites borassifolius (Sternberg) Unger (reconstruction by J. Svoboda).

(Fig. 3B, C). Abaxial cuticle from the holotype shows the same crypt as samples from Ovčín. Such a crypt does not occur in any other samples from the Czech Republic (similar crypt development is known from the Döhlen Basin, Germany) (Barthel 1964, Šimůnek 2007). Therefore we assign our specimens to the same species as Sternberg's original material. Unfortunately, the assignment of other plant organs such as seeds (Cardiocarpus) and strobili (Florinanthus volkmannii) to Cordaites borassifolius is not so straightforward because all organs were found isolated, not in organic connection to leafy twigs. However, as already stated above, these organs are associated with leaves which, based on cuticles, are identical to Cordaites borassifolius. Therefore we believe that Florinanthus volkmannii and Cordaitanthus ovatus strobili as well as Cardiocarpus seeds were produced by the same plant species, Cordaites borassifolius.
Although the seeds are platyspermic, they are not winged. They probably fell near the parent plant. We assign these seeds to Cordaites borassifolius.

The several specimens of the second fertile organ identified as Cordaitanthus ovatus were found in isolation. We consider these to also belong to Cordaites borassifolius, although we do not have organic attachment to prove this hypothesis. None of these fertile organs are well preserved. Thus, cuticular study is not possible. This type of fertile organ is more robust than Florinanthus volkmannii and therefore is considered to be female. No seeds were found in situ with this fertile organ so the gender of the cone remains in doubt.

Florinanthus volkmannii and "in situ" prepollen grains: Pollen sacs were probably overripe and not preserved in this fertile organ. However, accumulations of Florinites prepollen were found among the sterile scales (Fig. 30A), though this in itself does not prove beyond doubt that they are the prepollen of Cordaites borassifolius. However, it is more likely that this is the case than to suggest that they were transported by wind from an upland cordaitalean plant kilometres away. They have been classified as 3 species of cordaitalean prepollen, probably based on their maturity. Rare Artisia pith casts were also found in association with Cordaites borassifolius leaves. Even though their organic connection is not preserved, their affinity to Cordaites borassifolius is probable. It should be noted, however, that Artisia approximata, a species with few diagnostic features, occurs with many other cordaitalean species.

Summary of the whole plant concept: Based on cuticular studies, it has been proven that, of the possible cordaitaleans, only Cordaites borassifolius leaves are present in the bělka tuff bed in the roof of the Lower Radnice Coal, Radnice Basin. Given that the leaves are all of one type, then the other cordaitalean organs present, the seeds Cardiocarpus annularis and the male fertile organs Florinanthus ovatus, were found with accumulations of Cordaites borassifolius leaves. Therefore their affinity to Cordaites borassifolius is highly probable. The Artisia approximata pith cast and Cordaitanthus ovatus fertile organ were not found in organic connection with Cordaites borassifolius and their affinity to this species is less probable. However, there is only one cordaitalean species in the deposits thus the possibility that these organs belong to another cordaitalean species is not likely. The proposed reconstruction of Cordaites borassifolius can be seen in Fig. 33 .

The Stradonice locality (Hýskov relict) is important to the current discussion because it is the type locality of Florinanthus volkmannii. At least four types of cordaitalean fertile organs have been discovered from this locality, including Cordaitanthus triticus (Andrae) and Cardiocarpus orbiculare type seeds (Ettingshausen 1852). The others are not yet described. Adequate cuticular recovery from the cordaitaleans from Stradonice has been unsuc- 
cessful. It seems that at least two natural cordaitalean species occur at the Stradonice locality (Hýskov relict).

The cuticles of the different cordaitalean organs (leaves, cone scales, and seeds) found at the Ovčín localities exhibit different cellular details. These differences, however, are quite common and there are many examples in different plant groups. In the pteridosperm Laveineopteris for example, the cuticle of the pinnules differes from the cuticle of the cyclopterid of the same species (Cleal \& Shute 2003). In the cordaitaleans it has been demonstrated that the leaf cuticle of Cordaites schatzlarensis Šimůnek \& Libertín differs from the seed cuticle of Samaropsis newberryi (Andrews) Seward. Nevertheless, both morphogenera belong to one biological species (Šimůnek \& Libertín 2006). The fact that cuticles of different organs are not identical in all details does not preclude them from belonging to the same biological species. We believe this to be case for the cordaitalean remains found in the bělka bed at Ovčín; several cuticular types representing one biological species.

Concerning the botanical affinity of the large trunk fragment found in SE1, its identification as a cordaitelan remain is mostly indirect since no leaves were found attached to the branches. Nevertheless the character of branching and surface of the trunk clearly differentiate this specimen from associated calamites, medullosans, tree ferns and lepidodendrid (even decorticated) stems. Moreover, this stem is associated with leaves of Cordaites borassifolius, which again points to the conclusion that this is most likely the trunk of the same species. If so, this species was a fairly large tree.

\section{Conclusions}

Cordaites borassifolius represents a distinct cordaitalean leaf known from several localities in the Radnice Basin. Some cordaitalean leaves from Stradonice (Hýskov relict) probably also belong to this species. The venation of Cordaites borassifolius exhibits two patterns: the abaxial surface shows the typical venation of Cordaites borassifolius with alternating wide and narrow veins, whereas the adaxial side shows veins of approximately equal width.

Morphological features of the cuticle are significant for recognition of this species. The adaxial cuticle has orientated oblong cells and rare stomata more or less regularly dispersed on the leaf surface. Stomatal complexes of the abaxial cuticle, however, are arranged in multiple stomatal rows, forming stomatiferous bands. Each stoma (guard cells) is covered by a transverse outer stomatal cavity (crypt) that is a reliable diagnostic feature for this species. This feature has only been observed in Cordaites sp. type 6 by Barthel (1964) from the Permian strata of the Döhlen Basin in Germany.
Fertile organs found associated with the Cordaites borassifolius leaves are classified as two species. In accordance with the system of Ignatiev \& Meyen (1989), the male inflorescence found at both Stradonice (Hýskov relict) and the Radnice Basin is named Florinanthus volkmannii (Ettingshausen) nov. comb. [Representatives of "Cordaianthus" volkmannii described from other areas (United States, Great Britain and China) do not belong to this species. They are usually described as female fertile organs, and according to Ignatiev \& Meyen (1989), should be classified within the genus Grandeuryconus Ignatiev \& Meyen.] F. volkmannii has long bracts and very small fertile buds. The cuticle of the bracts shows orientated tetragonal cells and stomatal complexes arranged into single stomatal rows. The fertile axillary complexes are composed of 20 to 30 spatulate to lanceolate shaped scales. Small uniseriate trichomes grew from the scale margins. Pollen grains associated with these scales resemble dispersed Florinites ovalis Bharadwaj, Florinites guttatus Felix \& Burdbridge, and Pseudoillinites sp. Comparison of Bohemian "in situ" pollen grains with other cordaitalean "in situ" species could not be accomplished, because it was necessary to use SEM and TEM analysis for exact determination.

The second fertile organ is comparable to the North American Westphalian D species Cordaitanthus ovatus (Lesquereux) Ignatiev \& Meyen. Even though it is presumed to be female, its gender could not be unquestionably demonstrated. The sex of this inflorescence is indeterminate, and therefore it is classified as Cordaitanthus Feistmantel, which was established to accommodate cordaitalean fertile organs of indeterminate sex.

The seeds from SE, discovered in 2006 are similar to Cardiocarpus annularis (Sternberg) Lesquereux. The cuticle of seed integuments consists of polygonal cells. The strongly cutinised cells with thick walls probably covered the sclerotesta whereas the two-layerd thin cuticle covered the sarcotesta.

Twigs and pith casts were previously described by Sternberg $(1821,1825)$ as Calamites fasciatus Sternberg and as Tithymalites biformis Presl by Presl in Sternberg (1838). The valid name is Artisia approximata Brongniart ex Lindley \& Hutton.

Cordaites borassifolius was an important element of the peat-forming floras of the Radnice Basin and shared the ecosystem with peat-forming lepidodendrids. In life, it was a tree of medium height, reaching $20 \mathrm{~m}$ high.

\section{Acknowledgement}

This research was supported by the Grant Agency of the Czech Republic, grants 205/05/2034 and 205/05/0105 and it is a part of the Research project of the CGS No. MZP0002579801 and of Charles University in Prague, Faculty of Science MSM 
0021620855. The authors thank P. Týcová from the laboratory of the Czech Geological Survey, Prague and A. Langrova from the Academy of Science of the Czech Republic for SEM digital images of cordaitalean cuticles, also J. Pšenička for making available cordaitalean remains from the West Bohemian Museum in Plzeň, and M. Libertín for enabling us to study in the National Museum in Prague. The authors are obliged to A. Bashforth (Coppenhagen, Denmark) and to D. Chaney (Washington, USA) for checking this manuscript and to C. Cleal (Cardiff, Great Britain) for his valuable remarks.

\section{References}

ALPERN, B. 1959. Contribution à l'étude palynologique et petrographique des charbons français. 314 pp. Ph.D. thesis, Faculté des Sciences, Université de Paris.

ANDRAE, C.J. 1864. Die Versteinerungen der Steinkohlenformation von Stradonitz in Böhmen. Neues Jahrbuch für Mineralogie, Geologie und Palaeontologie 1864, 160-176.

ANDREWS, H.N. JR. 1970. Index of generic names of fossil plants, 1820-1965. Geological Survey Bulletin 1300, 1-353.

ANDrusov, D., ČEPEK, L., Hynie, O., KeTtNer, R., KodyM, O. \& URBAN, K. 1940. Vysvětlivky ke geologické mapě protektorátu Čechy a Morava, List Královice 4051. Knihovna Geologického ústavu pro Čechy a Moravu 19, 1-142.

BALME, B.E. 1995. Fossil in situ spores and pollen grains an annotated catalogue. Review of Palaeobotany and Palynology 87, 81-323. DOI 10.1016/0034-6667(95)93235-X

BALME, E.B. \& HENELly, J.P.F. 1955. Bisaccate sporomorphs from Australian Permian coals. Australian Journal of Botany 3, 89-98. DOI 10.1071/BT9550089

BARTHEL, M. 1964. Coniferen- und Cordaiten-Reste aus dem Rotliegenden des Döhlener Beckens. Geologie (Berlin) 13(1), 60-89.

BHARADWAJ, D.C. 1957. The palynological investigations of the Saar coals. Part I - Monography of sporae dispersae. Palaeontographica B 101, 73-125.

BRONGNiART, A. 1828. Prodrome d'une histoire des végétaux fossiles. Dictionaire des sciences naturelles 57, 1-223.

BRUSH, G.S. \& BARGHOORN, E.S. 1962. Identification and structure of cordaitean pollen. Journal of Paleontology 36, 1357-1360.

BuCHHOLZ, J.T. \& GRAY, N.E. 1948. A taxonomic revision of Podocarpus. I. The sections of the genus and their subdivisions with special reference to leaf anatomy. Journal of Arnold Arboretum 50, 49-63.

BUTTERWORTH, M.A. \& Williams, R.W. 1954. Description of nine species of small spores from the British Coal Measures. The Annals and Magazine of Natural History 12(7), 753-764.

CleAl, C.J. \& SHUTE, C.H. 2003. Systematics of the Late Carboniferous medullosalean pteridosperm Laveineopteris and its associated Cyclopteris leaves. Palaeontology 46(2), 353-411. DOI 10.1111/1475-4983.00303

CORDA, A.C.J. 1845. Beiträge zur Flora der Vorwelt. 128 pp. C.J. Calvesche Buchhandlung, Prag.
CostanZA, S.H. 1985. Pennsylvanioxylon of Middle and Upper Pennsylvanian coals from the Illinois Basin and its comparison with Mesoxylon. Palaeontographica B 197(4-6), 81-121.

CRIDland, A.A. 1964. Amyelon in American coal balls. Palaeontology 7, 186-209.

CROOKALL, R. 1970. Fossil plants of the Carboniferous rocks of Great Britain. Memoirs of the Geological Survey of Great Britain. $2^{\text {nd }}$ section. Palaeontology 4(6), 793-840.

DAGHLIAN, C.P.\& TAYLOR, N.T. 1979. A new method for isolating pollen and spores from acetate peels for scanning electron microscopy. Review of Palaeobotany and Palynology 27(1), 85-89. DOI 10.1016/0034-6667(79)90046-0

DARRAH, W.C. 1952. The material and methods of palaeobotany. Palaeobotanist 1, 145-153.

DELEVORYAS, T. 1953. A new male cordaitean fertile organ from the Kansas Carboniferous. American Journal of Botany 40, 144-150. DOI 10.2307/2438771

DiMichele, W.A. \& PhILIPS, T.L. 1994. Paleobotanical and Paleoecological constraints on models of peat formation in the Late Carboniferous of Euramerica. Palaeogeography, Palaeoclimatology, Palaeoecology 106, 39-90.

DOI 10.1016/0031-0182(94)90004-3

DYBOVÁ, S. \& JACHOWITZ, A. 1957. Microspores of the Upper Silesian Coal Measures. Prace Institutu geologicznego 23, $1-328$.

ETTINGSHAUSEN, C. 1852. Die Steinkohlenflora von Stradonitz in Böhmen. Abhandlungen der Kaiserlich-königlichen geologischen Reichsanstalt in Wien 1(3), 1-18.

FALCON-LANG, H.J. 2003. Late Carboniferous Tropical Dryland Vegetation in an Alluvial-plain Setting, Joggins, Nova Scotia, Canada. Palaios 18, 197-211.

DOI 10.1669/0883-1351(2003)018<0197:LCTDVI >2.0.CO;2

FALCON-LANG, H.J. 2005. Small cordaitalean trees in a marine-influenced coastal habitat in the Pennsylvanian Joggins Formation, Nova Scotia. Journal of the Geological Society of London 162, 485-500. DOI 10.1144/0016-764904-080

FALCON-LANG, H.J. \& BASHFORTH, A.R. 2004. Pennsylvanian uplands were forested by gigant cotdaitalean trees. Geology 32(5), 417-420. DOI 10.1130/G20371.1

FALCON-LANG, H.J. \& SCOTT, A.C. 2000. Upland ecology of some Late Carboniferous cordaitalean trees from Nova Scotia and England. Palaeogeography, Palaeoclimatology, Palaeoecology 156, 225-242.

DO1 10.1016/S0031-0182(99)00142-X

FEISTMANTEL, O. 1876. Versteinerungen der böhmischen Kohlen-ablagerungen, 3. Palaeontographica, Band 23, 223-316.

FeliX, C.J. \& BuRdBridge, P.P. 1967. Palynology of the Springer Formation of southern Oklahoma, U.S.A. Palaeontology 10, 349-425.

FLORIN, R. 1931. Untersuchungen zur Stammesgeschichte der Coniferales und Cordaitales. Kunglige Svenska vetenskapsakademiens handlingar, Serie III 10(1), 1-588.

FLORIN, R. 1936. On the structure of the pollen-grains in the Cordaitales. Svensk Botanisk Tidskrift 30, 624-651.

FRY, W.L. 1956. New cordaitean cones from the Pennsylvanian of Iowa. Journal of Paleontology 30, 35-45. 
GRAND'EURY, C. 1877. Flore carbonifère du départment da la Loire et du centre de la France. Mémoires présentés par divers savants à l'Académie des Sciences, Première partie Botanique. 624 pp. Imprimerie Nationale, Paris.

HAVLENA, V. 1971. Dvě rostlinné zkameněliny nové pro namur hornoslezské pánve (Two new plant fossils found in the Namurian of the Upper Silesian Basin). Časopis pro mineralogii a geologii 16(4), 449-451.

IGNATIEV, I.A. \& MEYEN, S.V. 1989. Suchoviella - gen. nov. from the Permian of Angaraland and a review of the systematics of Cordaitanthales. Reviev of Palaeobotany and Palynolynology 57, 313-339.

DOI 10.1016/0034-6667(89)90028-6

KALIBOVÁ, M. 1965. New species of miospores from the Bohemian Stephanian. Sborník geologických věd, Paleontologie 6, 39-59.

KERP, H. 1990. The study of fossil gymnosperms by means of cuticular analysis. Palaios 5, 548-549. DOI $10.2307 / 3514861$

KERP, H. \& KRINGS, M. 1999. Light microscopy of fossil cuticles, 52-56. In JONES, T.P. \& ROwE, N.P. (eds) Fossil plants and spores. Modern techniques. Geological Society, London.

KIDSTON, R. 1911. Les végétaux houillers recueillis dans le Hainaut Belge. Mémoires du Musée royal d'histoire naturelle de Belgique 5(4), 1-282.

KoSANKE, R.M. 1950. Pennsylvanian spores of Illinois and their use in correlation. Illinois Geological Survey Bulletin 74, $1-128$.

KOSANKE, R.M. 1982. Illustrations and comments concerning the type specimens of Calamospora, Florinites, and Raistrickia. Journal of Paleontology 56(5), 1171-1176.

KRINGS, M. \& KERP, H. 1997. An improved method for obtaining large pteridosperm cuticles. Review of Palaebotany and Palynology 96, 453-456. DOI 10.1016/S0034-6667(96)00059-0

KVAČEK, J. \& StRAKOVÁ, M. 1997. Catalogue of fossil plants described in works of Kaspar M. Sternberg. 201 pp., 67 pls. National Museum, Prague.

LEE, HSING-HsÜEH 1963. Fossil plants of the Yuehmenkou Series, North China. Palaeontologia Sinica, New Series A 148(6), 100-186.

LESQUEREUX, L. 1880. Description of the coal flora of the Carboniferous formation in Pennsylvania and throughout the United states. Pennsylvania $2^{\text {nd }}$ Geological Survey Report Progress 1, 1-354; 2, 355-694, pl. 86, Atlas 1879, pls 1-85.

LESQUEREUX, L. 1884. Description of the coal flora of the Carboniferous formation in Pennsylvania. Pennsylvania $2^{\text {nd }}$ Geological Survey Report Progress 3, 695-977, pls 88-111.

LINDLEY, J. \& HUTTON, W. 1837. The fossil flora of Great Britain, or figures and descriptions of the vegetable remains found in a fossil state in the country. Volume 3, 123-205. James Rigdway \& Sons, London.

MAŠEK, J. 1963. Složení a vznik brouskového horizontu ve středočeské kamenouhelné pánvi (Die Zussammensetzung und Entstehung des Schleifsteinhorizontes im Mittelböhmischen
Steinkohlbecken). Časopis pro mineralogii a geologii 8, 175-177.

MEYEN, S.V. 1984. Basic features of gymnosperm systematics and phylogeny as evidenced by the fossil record. The Botanical Review 50(1), 1-112. DOI 10.1007/BF02874305

MEYEN, S.V. 1987. Fundamentals of palaeobotany. 432 pp. Chapman \& Hall, London.

MiLLAY, M.A. \& TAYLOR, T.N. 1974. Morphological studies of Paleozoic saccate pollen. Palaeontographica, Abteilung B 147, 75-99.

Millay, M.A. \& TAYLOR, T.N. 1976. Evolutionary trends in fossil gymnosperm pollen. Review of Palaeobotany and Palynology. Patterns in gymnosperm evolution 21(1), 65-91.

NĚMEJC, F. 1968. Paleobotanika III. 478 pp. Academia, Praha.

NEWBERRY, J.S. 1873. Description of fossil plants from the Coal Measures of Ohio. Ohio Geological Survey Report 1(2), Palaeontology 3, 359-385.

NIKLAS, K.J. 1994. Predicting the height of fossil plant remains: an allometric approach to an old problem. American Journal of Botany 81, 1235-1243. DOI 10.2307/2445398

OpLUŠTIL, S. 2005. Evolution of the Middle Westphalian river valley drainage system in central Bohemia (Czech Republic) and its palaeogeographic implication. Palaeogeography, Palaeoclimatology, Palaeoecology 222, 223-258.

DOI 10.1016/j.palaeo.2005.03.016

OPLUŠTIL, S., PŠENIČKA, J., LIBERTÍN, M. \& BEK, J. 2005. Peat-forming plant assemblages conserved in volcanic ash of the Whetstone Horizon (Bolsovian) in central and western Bohemia, Czech Republic. North American Paleontology Convention, Dalhousie University, Halifax, Nova Scotia, Canada. PaleoBios 25, Supplement 2, 92-93.

OPLUŠTIL, S., PŠENIČKA, J., LIBERTÍN, M. \& ŠIMŮNEK, Z. 2007. Vegetation patterns of Westphalian and Lower Stephanian mire assemblages preserved in tuff beds of thecontinental basins of Czech Republic. Review of Palaeobotany and Palynology 143, 107-154.

DO] 10.1016/j.revpalbo.2006.06.004

OPLUŠTIL, S., PŠENIČKA, J., LIBERTÍN, M., BASHFORTH, A.R., ŠIMŮNEK, Z., DRÁBKOVÁ, J. \& DAŠKOVÁ, J. 2009. A Middle Pennsylvanian (Bolsovian) peat-forming forest preserved in situ in volcanic ash of the Whetstone Horizon in the Radnice Basin, Czech Republic. Review of Palaeobotany and Palynology 155, 234-274.

DOI 10.1016/j.revpalbo.2009.03.002

PEPPERS, R.A. 1970. Correlation and palynology of coals in the Carbondale and Spoon formations (Pennsylvanian) of the northeastern part of the Illinois Basin. Illinois State Geological Survey Bulletin 93, 1-173.

PEŠEK, J. 1994. Carboniferous of Central and Western Bohemia (Czech Republic). 64 pp. Czech Geological Survey, Prague.

POTONIÉ, R. 1962. Regeln, nach denen sich die Sekundaerfalten der Sporen bilden. Palaeontologische Zeitschrift 36(1-2), $46-54$.

POTONIÉ, R. 1967. New phylogenetic facts on fossil spores. Review of Palaeobotany and Palynology 1(1-4), 75-82.

DOI 10.1016/0034-6667(67)90111-X 
POTONIÉ, R. \& KREMP, G. 1956. Die Sporae dispersae des Ruhrkarbons; ihre Morphographie und Stratigraphie mit Ausblicken auf Arten anderer Gebiete und Zeitabschnitte, Teil II. Palaeontographica, Abteilung B 99, 85-186.

RAVN, R.L. 1979. An introduction to the stratigraphic palynology of the Cherokee Group (Pennsylvanian) coals of Iowa. Iowa Geological Survey, Technical Paper 6, 1-117.

RENAULT, B. 1879. Structure comparée de quelques tiges de la flore Carbonifère. Nouvelles Archives du Muséum d'histoire naturelle de Paris 2, 213-348.

RENAUlT, B. 1881. Cours de botanique fossile. Volume 1. 184 pp. G. Masson, Paris.

RenAult, B. 1896. Études des gîtes mineraux de la France. Bassin houiller et permien d'Autun et d'Épinac. IV. Flore fossile, I. 578 pp. Imprimerie Nationale, Paris.

ROTHWELL, G.W. \& WARNER, S. 1984. Cordaixylon dunusum $\mathrm{n}$. sp. (Cordaitales) I. Vegetative structures. Botanical Gazette 145(2), 275-291. DOI 10.1086/337456

SCHOPF, J.M., WILSON, L.R. \& BENTALL, R. 1944. An annotated synopsis of Paleozoic fossil spores and the definition of generic groups. Illinois State Geological Survey, Report of investigations 28(10), 1-73.

SEWARD, A.C. 1917. Fossil plants. Volume III. Pteridospemae, Cycadofilices, Cordaitales, Cycadophyta. 656 pp. Hafner Publishing Company, New York \& London (reprint 1963).

SIMŮNEK, Z. 2000. Cuticles of Cordaites from the Westphalian, Stephanian and Autunian of the Bohemian Massif (Czech Republic). A preliminary report. Acta Palaeobotanica 40(1), $25-34$.

ŠIMŮNEK, Z. 2001. Kordaity svrchního karbonu a permu Českého masivu (Cordaites from the Upper Carboniferous and Permian of the Bohemian Massif; A study of epidermal structures). 125 pp. Ph.D. thesis, Czech Geological Survey, Prague. [in Czech]

SIMŮNEK, Z. 2007. New classification of the genus Cordaites from the Carboniferous and Permian of the Bohemian Massif, based on cuticle micromorphology. Sborník Národního muzea v Praze, Řada B - prírodní vědy 62(3-4), 97-210.

S̆IMŮNEK, Z. \& LIBERTÍN, M. 2006. Cordaites schatzlarensis sp. nov. and Samaropsis newberryi (Andrews) Seward from the Westphalian (Carboniferous) of the Žaclér area (Czech Republic). Review of Palaeobotany and Palynology 138, 43-62. DOI 10.1016/j.revpalbo.2005.10.001

STERNBERG, K. VON 1820. Versuch einer geognostisch-botanischer Darstellung der Flora der Vorwelt I, 1. 24 pp. F. Fleischer, Leipzig.

STERNBERG, K. VON 1821. Versuch einer geognostisch-botanischer Darstellung der Flora der Vorwelt I, 2. 33 pp. F. Fleischer, Leipzig.

STERNBERG, K. VON 1825. Versuch einer geognostisch-botanischer Darstellung der Flora der Vorwelt I, 4. 48 pp. Ernst Brenck's, Regensburg.
STERnBerG, K. VON (PRESL, C.B \& CORDA, A.J. co-authors) 1838. Versuch einer geognostisch-botanischer Darstellung der Flora der Vorwelt II, 7/8, 81-220. Gotlieb Hässe Söhne, Prague.

STOCKEY, R.A. \& ATKINSON, I.A. 1993. Cuticle micromorphology of Agathis Salisbury. International Journal of Plant Sciences 154(1), 187-225. DOI 10.1086/297104

Stockey, R.A., Frevel, B.J. \& Woltz, P. 1998. Cuticle micromorphology of Podocarpus, subgenus Podocarpus, section Scytopodium (Podocarpaceae) of Madagascar and South Africa. International Journal of Plant Sciences 159(6), 923-940.

StOCKeY, R.A., Ko, H. \& WolTZ, P. 1992. Cuticle micromorphology of Falcatifolium De Laubenfels (Podocarpaceae). International Journal of Plant Sciences 153(4), 589-601. DOI $10.1086 / 297082$

StOCKeY, R.A., Ko, H. \& WolTZ, P. 1995. Cuticle micromorphology of parasitaxus De Laubenfels (Podocarpaceae). International Journal of Plant Sciences 156(5), 723-730. DOI $10.1086 / 297294$

TAYLOR, N.T. 1981. Pollen and pollen organ evolution in early seed plants, 1-25. In NiKLAS, K.J. (ed.) Paleobotany, paleoecology and evolution, vol. 1. Praeger, New York.

TAYLOR, N.T. 1988. Pollen and Pollen organs of fossil gymnosperms: phylogeny and reproductive biology, 117-217. In BECK, C.B. (ed.) Origin and Evolution of Gymnosperms. Columbia University Press, New York.

TRIVETT, M.L. \& ROTHWELL, G.W. 1985. Morphology, systematics, and paleoecology of Paleozoic fossil plants: Mesoxylon priapi sp. nov. (Cordaitales). Systematic Botany 10(2), 205-223. DOI 10.2307/2418347

TUREK, V. 1989. Fish and amphibian trace fossils from Westphalian sediments of Bohemia. Palaeontology 32(3), 623-643.

UNGER, F. 1850. Genera et species plantarum fossilium. 627 pp. Wilhelm Braunmüller, Wien.

VAn Amerom, H.W.J. 1998. Fossilium Catalogus Plantae. Pars 99, Cordaitales und einige Vertreter der Monocotylen 1. Supplement. 195 pp. Backhuys Publishers, Leiden.

WeITHOFER, K.A. 1902. Geologische Skizze des Kladno-Rakonitzer Kohlenbeckens. Verhandlungen der Kaiserlichköniglichen geologischen Reichsanstalt, 399-420.

ZEILLER, R. 1886-1888. Études des gîtes minéraux de la France. Flore fossile du bassin houiller de Valencienes. $731 \mathrm{pp}$. (text 1888), pls 1-94 (Atlas 1886). Quantin, Paris.

ZODROW, E.L., MASTALERZ, M. \& ŠIMU゚NEK, Z. 2003. FTIR-derived characteristics of fossil-gymnosperm leaf remains of Cordaites principalis and Cordaites borassifolius (Pennsylvanian Maritimes Canada and Czech Republic). International Journal of Coal Geology 55, 95-102. DOI $10.1016 / \mathrm{S} 0166-5162(03) 00084-3$ 